\title{
Ensinando Matemática por meio de situações potencialmente adidáticas: estudo de casos envolvendo Análise Combinatória
}

\author{
Wanessa Aparecida Trevizan
}

\author{
DISSERTAÇÃO APRESENTADA AO \\ INSTITUTO DE MATEMÁTICA E ESTATÍSTICA DA \\ UNIVERSIDADE DE SÃO PAULO \\ COMO REQUISITO PARCIAL PARA \\ OBTENÇÃO DO TÍTULO DE \\ MESTRE EM CIÊNCIAS NO \\ PROGRAMA DE MESTRADO PROFISSIONAL EM \\ ENSINO DE MATEMÁTICA SOB ORIENTAÇÃO DO \\ PROFESSOR DR. ANTONIO CARLOS BROLEZZI
}

São Paulo, Fevereiro de 2015 


\section{Ensinando Matemática por meio de situações potencialmente adidáticas: estudo de casos envolvendo Análise Combinatória}

Wanessa Aparecida Trevizan

São Paulo, Fevereiro de 2015 


\section{Ensinando Matemática por meio de situações potencialmente adidáticas: estudo de casos envolvendo Análise Combinatória}

Wanessa Aparecida Trevizan

Comissão Julgadora:

- Prof. Dr. Antonio Carlos Brolezzi (orientador) - IME-USP

- Prof $^{a}$. Dr ${ }^{a}$. Iole de Freitas Druck - IME-USP

- Prof. Dr. Rogério Ferreira da Fonseca - PUC 


\section{Agradecimentos}

Agradeço primeiramente a Deus pelo depósito diário que tem feito em minha vida de 86400 segundos, os quais assumi a responsabilidade de administrar, desempenhando da melhor maneira possivel todas as tarefas que Ele me permitir realizar. Ao fazer esse investimento, Deus também me deu todas as condições necessárias para que eu pudesse lutar e conquistar cada sonho: a liberdade, que me permite escolher os caminhos; as experiências, que me ensinam a fazer cada escolha; o amor, sem o qual nada mais teria importância; e as pessoas maravilhosas, que me motivam a prosseguir em todas as circunstâncias.

Agradeço aos meus pais Alencar e Marcia, exemplos de vida, de dedicação e esforço, companheiros incansáveis, com os quais eu posso contar sempre. Agradeço por todas as vezes que abriram mão de suas próprias vidas para zelar da nossa, no ensino, na atenção, no incentivo, no exemplo, no amor. Em meio a momentos bons e em meio a momentos difíceis, seu carinho e dedicação sempre foram constantes, por isso nunca senti falta de nada.

Agradeço à minha irmã Andressa, melhor amiga. Juntas, nós crescemos e construímos projetos de vida na mesma direção. Frequentemente compartilhamos dúvidas, expectativas, ideias, reflexões e anseios com relação às mais diversas causas da Educação, pelas quais nos esforçamos em contribuir com nossa prática, nosso exemplo e nossa pesquisa.

Agradeço meu esposo Mauricio, que me ensinou um jeito diferente de amar e de valorizar a vida. Agradeço pela compreensão em momentos difíceis (principalmente os que antecedem as datas de entrega de trabalho) nos quais falta tempo para dedicar ao meu lar a atenção que ele merece.

Agradeço imensamente ao meu professor Antonio Carlos Brolezzi, que teve, em sua função de orientador, não apenas um título, mas uma responsabilidade de confecer o 
projeto e abraçá-lo; de ouvir minhas ideias, mas criticá-las e mostrar novas referências; de valorizar meu trabalho, mas revisá-lo e corrigi-lo; de respeitar minhas limitações, mas mostrar caminhos de superação.

Agradeço tantos e tantos parentes e amigos dos quais não devo citar nenhum nome para não cometer a injustiça de esquecer alguém, mas que certamente se sentirão lembrados ao ler este parágrafo, pois eles estiveram presentes durante toda a trajetória do presente trabalho e conhecem muito bem seus "altos e baixos". Não apenas conhecem de assistir, mas de ajudar, aconselhar e apoiar.

Agradeço à minha amiga de infância Amanda que, apesar de não estar mais entre nós, participou de parte dessa trajetória e que, de repente sem que eu esperasse, me fez entender que a infância e a escola não são uma fase de preparação para a vida, mas sim parte da vida.

Agradeço a tantos professores maravilhosos que tive no mestrado e em especial aos professores Iole de Freitas Druck(IMME-USP), Rogério Ferreira da Fonseca (PUC) e Elio Carlos Ricardo (FEUSP), pelas contribuições valiosas que deram ao meu trabalho.

Também aos professores da Escola de Aplicação Ernani Nagy de Moraes e Josenilton Andrade de Franca, que desde a licenciatura são referências para mim; aos licenciandos do IMME-USP, alunos do SESI e alunos da Escola de Aplicação da USP que participaram deste trabalho; às instituições SESI-Vila Leopoldina, ao IFSP- campus de Suzano e aos profissionais que delas fazem parte, por me acolherem profissionalmente $e$ me apoiarem nesta pesquisa.

Por fim, a todos os professores e alunos que passaram e que passam pela minha história deixando uma marquinha de aprendizado, pois ensinar e aprender são as tarefas mais importantes da vida, como procurei demonstrar nesses agradecimentos, como procurei demonstrar nessa dissertação e como continuarei tentando demonstrar a cada dia em que Deus confiar a mim os 86400 segundos. 
"A alegria não chega apenas no encontro do achado, mas faz parte do processo da busca. E ensinar e aprender não pode dar-se fora da procura, fora da boniteza e da alegria". (Paulo Freire) 
"Aprender Matemática sem forte intervenção da sua faceta investigativa é como tentar aprender a andar de bicicleta vendo os outros andar e recebendo informação sobre como o conseguem. Isso não chega. Para verdadeiramente aprender é preciso montar a bicicleta e andar, fazendo erros e aprendendo com eles". (Carlos Braumann) 


\section{Resumo}

TREVIZAN, W. A. Ensinando Matemática por meio de situações potencialmente adidáticas: estudo de casos envolvendo Análise Combinatória. Dissertação (Mestrado) Instituto de Matemática e Estatística, Universidade de São Paulo, São Paulo, 2014.

Diante de um cenário de contradições do atual ensino da Matemática, no qual a prática tem se revelado insatisfatória para se alcançar os objetivos declarados para tal disciplina em documentos oficiais, sugerimos a situação adidática, um conceito da Teoria das Situações de Brousseau (1933-), como ferramenta para uma aprendizagem matemática mais autônoma, ou seja, uma aprendizagem que possibilite o desenvolvimento de habilidades investigativas, interpretativas, críticas e criativas. A Teoria das Situações, elaborada pelo pesquisador francês Brousseau, é uma ferramenta de análise. Desse modo, a situação adidática é um conceito que permite modelar determinadas situações de aprendizagem a serem analisadas. O objetivo do presente trabalho é mostrar que este conceito também serve como instrumento metodológico, à medida que o docente, de posse dele, pode planejar situações potencialmente adidáticas em sala de aula. Baseada nesta teoria e em outras da Didática Francesa, bem como nas concepções de aprendizagem e desenvolvimento de Vigotski (1896-1934), buscamos analisar a aplicação de uma Sequência Didática em três momentos diferentes, os quais revelam três cenários escolares também distintos e três passagens da minha experiência como pesquisadora e docente. A Sequência Didática, planejada visando potencializar uma situação adidática, aborda o tema Análise Combinatória através de uma narrativa ficcional com desafios voltados para o Ensino Médio. Ao longo desse estudo, pudemos alcançar muito mais do que pretendíamos: percebemos que há fatores presentes na escola (independente de ser pública ou privada) que favorecem e fatores que desfavorecem o surgimento de uma situação adidática. No entanto, prosseguimos acreditando que planejar as aulas visando promover situações adidáticas, com todas as limitações presentes em nossa realidade educacional, é o melhor caminho para se chegar aos objetivos pretendidos para o ensino de Matemática, levando-se em conta as concepções de aprendizagem por nós adotadas.

Palavras-chave: Ensino de matemática, Situação adidática, Análise Combinatória 


\begin{abstract}
TREVIZAN, W.A. Teaching Mathematics through potentially adidactic situations: case studies involving Combinatorial Analysis. Thesis (MA) - Mathematics and Statistics Institute, University of São Paulo, São Paulo, 2014.

Facing a background of dramatic contradictions of the current mathematics teaching, in which the practice has been insufficient to achieve the stated objectives for such discipline in official documents, we suggest adidactic situation, a concept of Brousseau's (1933-)Theory of Situations, as a tool for learning mathematics more autonomous, ie, a learning that enables the development of investigative, interpretive, critical and creative skills. The Theory of Situations, prepared by the French researcher Brousseau, is an analysis tool. Thus, adidactic situation is a concept that allows to model certain learning situations to be analyzed. The objective of this paper is to show that this concept also serves as a methodological tool, as the teacher, holding it, can plan potentially adidactic situations in the classroom. Based on this theory and others of the French didactics, as well as in the conceptions of learning and development of Vygotsky (1896-1934), we analyze the application of a Teaching Sequence in three different moments, which also reveal three different school settings and three passes from my experience as a researcher and teacher. The Didactic Sequence, planned aiming at intensifying one adidactic situation, addresses the topic of Combinatorial Analysis through a fictional narrative with challenges facing High School. Throughout this study, we could achieve far more than we wanted: we realized that there are factors present in school (whether it be public or private) that favor and factors that disfavor the emergence of anadidactic situation. However, we continue to believe that planning lessons to promote adidactic situations, with all the limitations present in our educational reality is the best way to reach the objectives intended to mathematics teaching, taking into account the conceptions of learning we adopted.
\end{abstract}

Keywords: Math Teaching, Adidactic Situation, Combinatorial Analysis 


\section{Sumário}

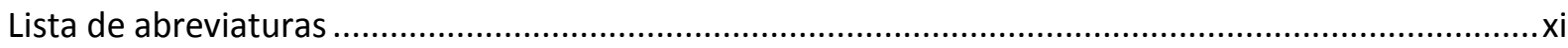

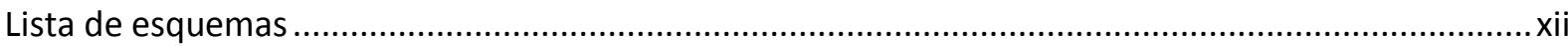

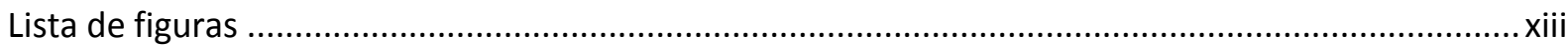

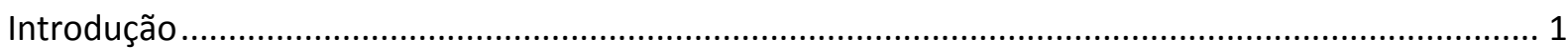

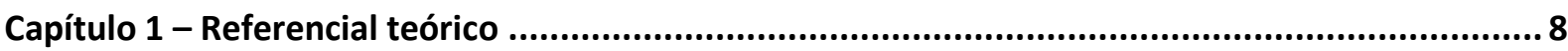

1.1 Uma breve caracterização do ensino público no Brasil ....................................................... 9

$1.2 \quad$ Uma teoria sobre a aprendizagem: Lev Vigotski............................................................. 14

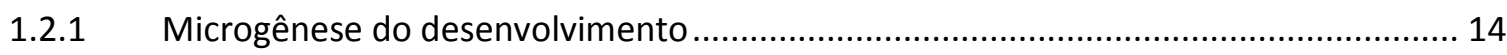

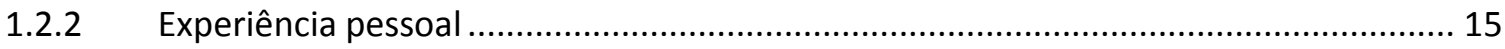

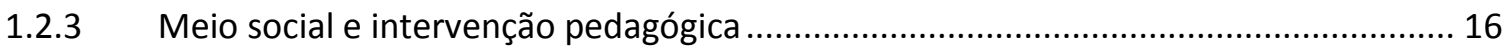

1.2.4 Zona de Desenvolvimento Proximal................................................................................. 16

1.3 A Didática da Matemática: contribuições francesas.......................................................... 17

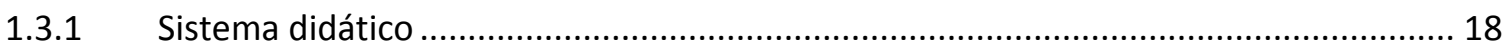

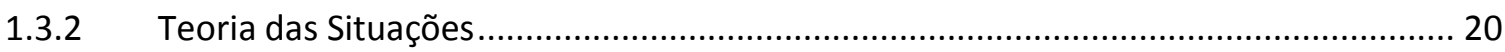

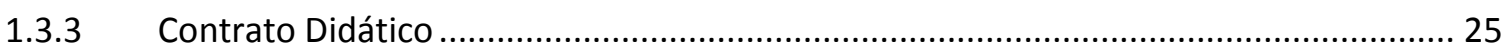

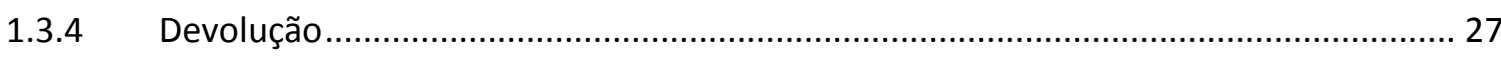

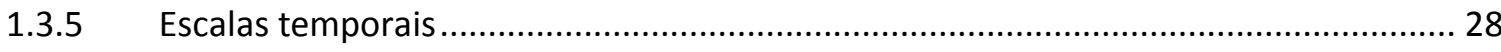

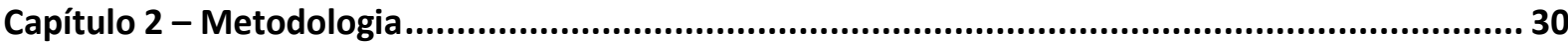

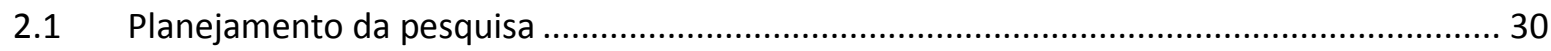

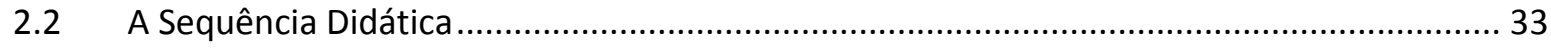

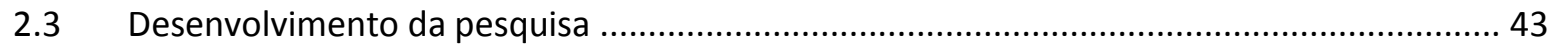

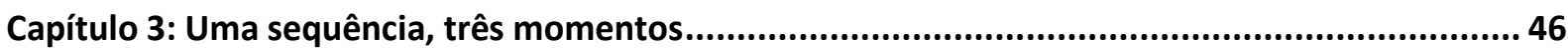

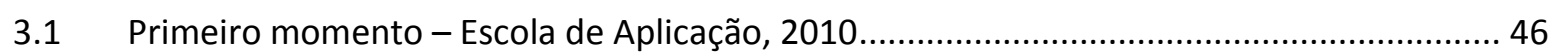

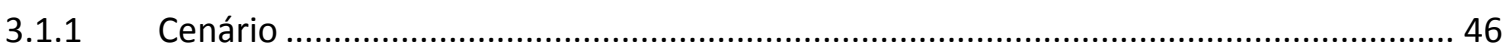

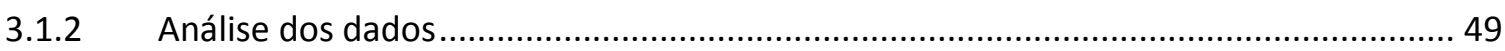

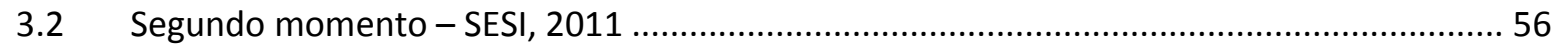

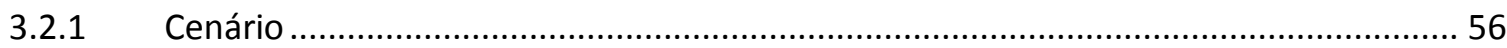

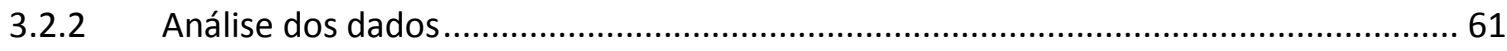

3.3 Terceiro momento - Escola de Aplicação, 2014 ................................................................. 65 


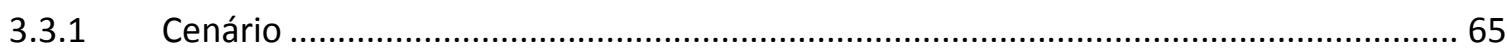

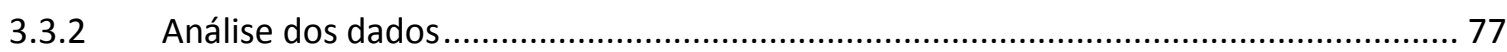

Conclusões sobre o terceiro momento ............................................................. 102

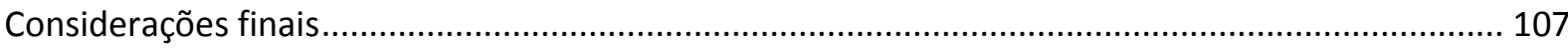

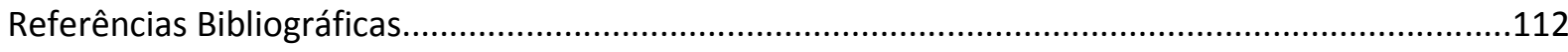

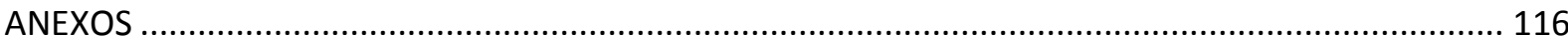

QUESTIONÁRIO PARA OS LICENCIANDOS EM MATEMÁTICA DO IME-USP BOLSISTAS DO PIBID NA ESCOLA DE APLICAÇÃO QUE PARTICIPARAM DO PROJETO “A CIDADE DE CONTAGEM”- SET/2014

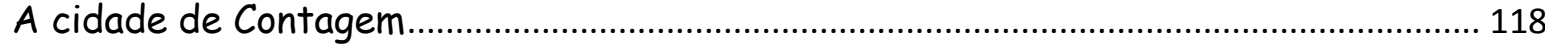

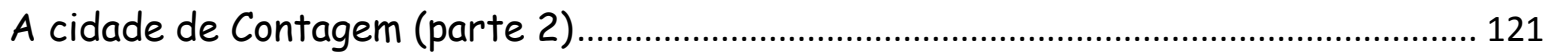




\section{Lista de abreviaturas}

Aluno(a) A, B, C e D - Alunos do $1^{\circ}$ momento de aplicação do projeto

Aluno(a) 1,2 e 3 - Alunos do $2^{\circ}$ momento de aplicação do projeto

Aluno(a) J, K, L e M- Alunos do $3^{\circ}$ momento de aplicação do projeto

A, B, C, D, E, F, G e H - Licenciandos bolsistas do PIBID na EA no $3^{\circ}$ momento de aplicação do projeto

EA - Escola de Aplicação da USP

FEUSP- Faculdade de Educação da Universidade de São Paulo

IME-USP - Instituto de Matemática e Estatística da Universidade de São Paulo

PFC- Princípio Fundamental da Contagem

PIBID- Programa Institucional de Bolsa de Iniciação à Docência

$\mathrm{W}$ - Wanessa no $1^{\circ}, 2^{\circ}$ ou $3^{\circ}$ momento de aplicação do projeto 


\section{Lista de esquemas}

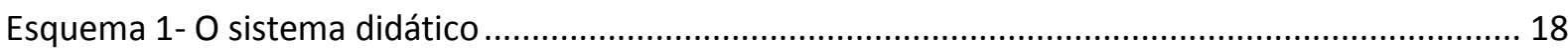

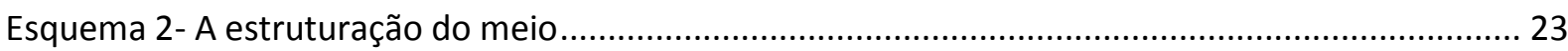

Esquema 3- As relações assimétricas com os saberes .................................................................. 28

Esquema 4- A dupla dimensão temporal da relação didática............................................................. 29

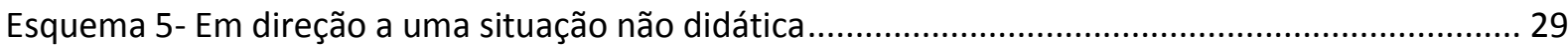




\section{Lista de figuras}

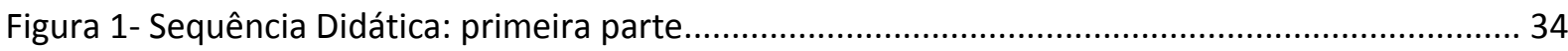

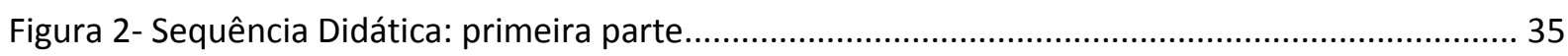

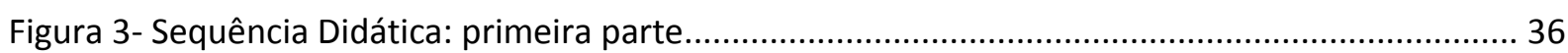

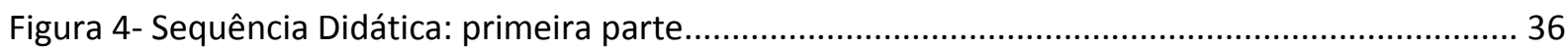

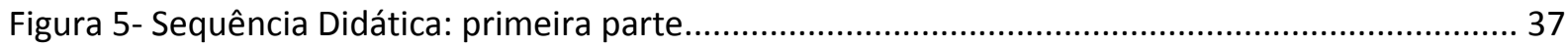

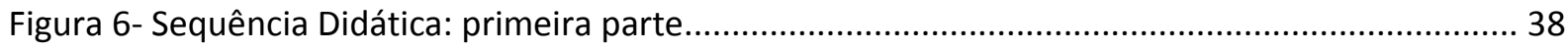

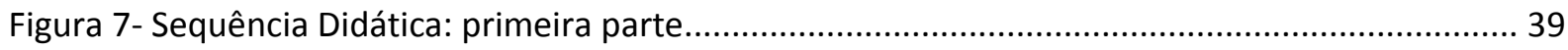

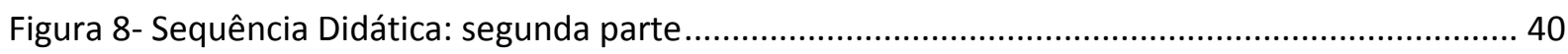

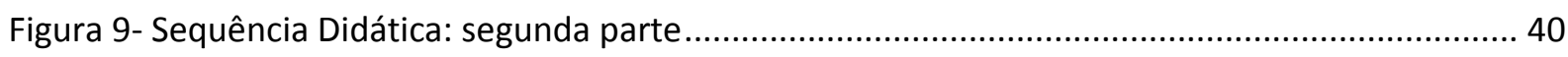

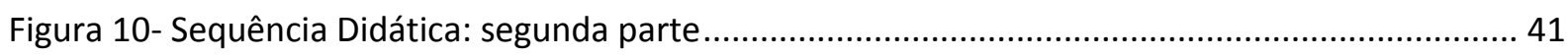

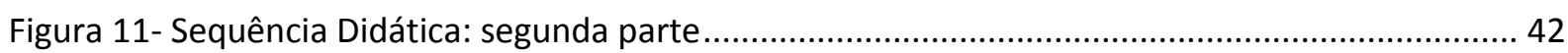

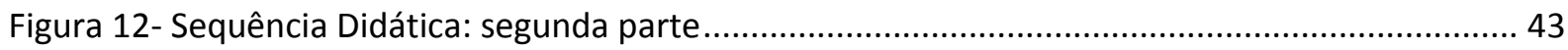

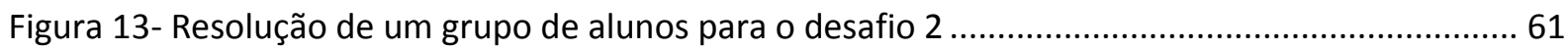

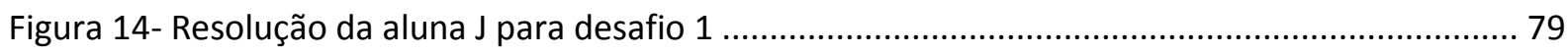

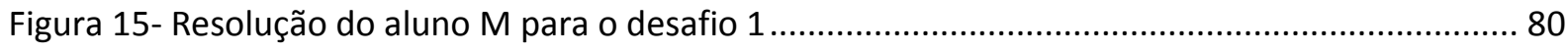

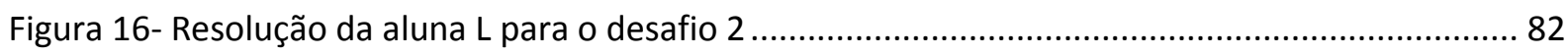

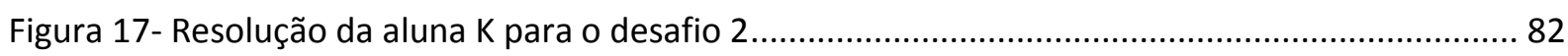

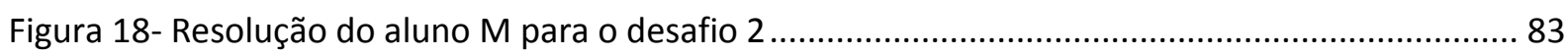

Figura 19- Resolução da aluna L para o desafio 2 (continuação) ...................................................... 84

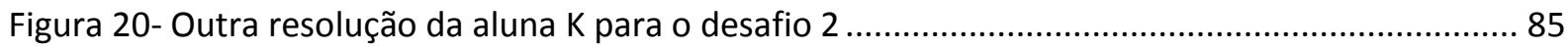

Figura 21- Outra resolução da aluna K para o desafio 2 (continuação) .............................................. 85

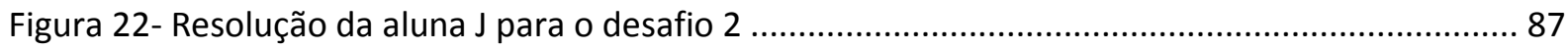

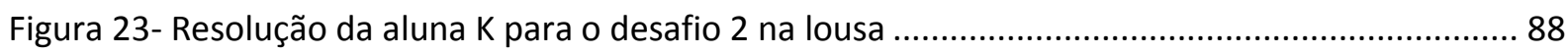

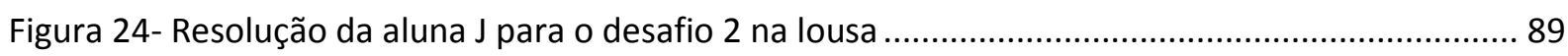


Figura 25- Resolução da aluna J para o desafio 3 91

Figura 26- Resolução da aluna J para o desafio 3 (continuação) 92

Figura 27- Resolução da aluna K para o desafio 3. 92

Figura 28- Resolução da aluna L para o desafio 3 93

Figura 29- Resolução da aluna J para o desafio 4 95

Figura 30- Dica com números concretos para o desafio 4 96

Figura 31- Resolução do aluno M para o desafio 4 97 


\section{Introdução}

É lugar comum falar-se em crise do ensino de Matemática, seja ele público ou privado. Pode-se constatar facilmente esse fato, no Brasil, pela observação do baixo desempenho geral em avaliações externas, sobretudo de Matemática.

Essa questão envolve fatores além dos metodológicos, mas é frequente a reflexão que envolve certa insatisfação com o chamado "método tradicional" de ensino de Matemática. Ainda que se possa discordar dessa expressão, já que tradicional não necessariamente significa o que se procura criticar em relação à prática comum das escolas de hoje, é possível defender uma crítica àquele método em que o professor desenvolve todo o raciocínio sozinho e pensa transmiti-lo ao aluno; oferece modelos para a resolução dos exercícios, na expectativa de que bastaria ao aluno realizar cópias e reproduzir técnicas. Essa forma de ensinar, que se pode criticar, acabaria por restringir as possibilidades de o aluno desenvolver estratégias e raciocinar. Ou seja, ela não seria adequada ao ensino de Matemática e contribuiria para a crise que mencionamos.

O fracasso em avaliações externas não deveria ser a principal preocupação, mas, sim, a sinalização dada por esse fracasso sobre a grande dificuldade, por parte dos estudantes, em utilizar as variadas ferramentas matemáticas em situações extraclasses. Isso é bastante grave, pois implica numa dificuldade da escola em cumprir o seu papel.

Partindo do princípio de que o ensino de Matemática visa desenvolver habilidades de raciocínio que colaboram para a autonomia diante do conhecimento e da resolução de problemas, e formar cidadãos com uma cultura matemática suficiente para uma atuação ativa na sociedade, deparamo-nos com a necessidade de práticas pedagógicas mais consistentes com tais objetivos.

Parece haver uma contradição entre aquilo que se espera do ensino de Matemática e aquilo que se aplica em sala de aula: de acordo com documentos oficiais, o ensino de Matemática no Ensino Médio visa

apresentar ao aluno o conhecimento de novas informações e instrumentos necessários para que seja possível a ele continuar aprendendo. Saber aprender é a condição básica para prosseguir aperfeiçoando-se ao longo da vida. Sem dúvida, cabe a todas as áreas do Ensino Médio auxiliar no desenvolvimento da autonomia e da capacidade de pesquisa, para que cada aluno possa confiar em seu próprio conhecimento. (BRASIL, 2000, p. 41) 
Ainda, de acordo com o PCN(EM), são objetivos do ensino de Matemática:

- compreender os conceitos, procedimentos e estratégias matemáticas que permitam a ele desenvolver estudos posteriores e adquirir uma formação científica geral;

- aplicar seus conhecimentos matemáticos a situações diversas, utilizando-os na interpretação da ciência, na atividade tecnológica e nas atividades cotidianas;

- analisar e valorizar informações provenientes de diferentes fontes, utilizando ferramentas matemáticas para formar uma opinião própria que lhe permita expressar-se criticamente sobre problemas da Matemática, das outras áreas do conhecimento e da atualidade;

- desenvolver as capacidades de raciocínio e resolução de problemas, de comunicação, bem como o espírito crítico e criativo;

- utilizar com confiança procedimentos de resolução de problemas para desenvolver a compreensão dos conceitos matemáticos;

- expressar-se oral, escrita e graficamente em situações matemáticas e valorizar a precisão da linguagem e as demonstrações em Matemática;

- estabelecer conexões entre diferentes temas matemáticos e entre esses temas e o conhecimento de outras áreas do currículo;

- reconhecer representações equivalentes de um mesmo conceito, relacionando procedimentos associados às diferentes representações;

- promover a realização pessoal mediante o sentimento de segurança em relação às suas capacidades matemáticas, o desenvolvimento de atitudes de autonomia e cooperação. (BRASIL, 2000, p. 42)

Corroboram com esses objetivos as Diretrizes Curriculares Nacionais para o Ensino Médio (BRASIL, 2012) ao citar em seu artigo 12 que o currículo do Ensino Médio deve "adotar metodologias de ensino e de avaliação de aprendizagem que estimulem a iniciativa dos estudantes".

Pode-se observar que a Matemática, seja do Ensino Médio, seja do Ensino Fundamental, público ou privado, não tem sido trabalhada de modo a contribuir para se alcançar as metas que são estabelecidas para a disciplina. Em vez de raciocinar, aprende-se a memorizar; em vez de deduzir, a acreditar. Em vez de adquirir ferramentas para sua vida extraescolar, o aluno adquire um novo conhecimento sem perceber sua relação com o conhecimento que adquire paralelamente fora da escola. Em vez de adquirir a habilidade de resolver problemas, o aluno é condicionado a responder alguns problemas-padrão do conteúdo que está vendo naquele momento, reproduzindo um procedimento fornecido pelo professor.

Como consequência disso, ocorre o baixo desempenho do aluno brasileiro em exames de nível nacional e internacional, que exigem mais do que a memorização de fórmulas. Exigem uma habilidade de apropriar-se do problema e desenvolver procedimentos adequados 
para a sua resolução, de maneira autônoma, mobilizando recursos cognitivos e selecionando os conhecimentos necessários.

A estrutura conceitual de avaliação do Enem, tendo como referência principal a articulação entre o conceito de educação básica e o de cidadania, tal como definidos nos textos constitucionais e na [...] LDB [1996], encontra-se inteiramente em consonância com os preceitos do Pisa, que está desenhado a partir de um modelo dinâmico de aprendizagem, no qual conhecimentos e habilidades devem ser continuamente adquiridos para uma adaptação bem- sucedida em um mundo em constante transformação. (BRASIL, 2001, p.44)

O desempenho brasileiro em Matemática no PISA, Programa Internacional de Avaliação de Estudantes, tem sido péssimo. A avaliação é feita a cada três anos com alunos de 15 anos de idade de diversos países. O Brasil obteve os seguintes resultados em Matemática nos dois últimos exames cujo foco era essa área do conhecimento: último colocado entre os 41 países em 2003 e 58 colocado entre 65 países em 2012.

De acordo com Watanabe (2007, p. 17) a causa do péssimo desempenho brasileiro no PISA é que suas questões "exigem pouco conteúdo, pouca memória, mas (...) examinam a capacidade dos alunos de analisar, raciocinar e refletir ativamente sobre seus conhecimentos e experiências, enfocando competências que serão relevantes para suas vidas futuras", o que não é explorado geralmente em nossas aulas de Matemática.

E no ENEM não é muito diferente. O Exame Nacional do Ensino Médio do INEP começou avaliar em 1998 os alunos brasileiros que haviam concluído ou que estavam para concluir o Ensino Médio. De 1998 a 2008, a avaliação foi feita de acordo com 5 competências: I. Dominar linguagens; II. Compreender fenômenos; III. Enfrentar situaçõesproblema; IV. Construir argumentação; V. Elaborar propostas.

Como menciona Machado (2009, p. 49), esse espectro de competências foi elaborado por uma equipe multidisciplinar de professores "conscientizados de que, na educação básica, as disciplinas são meios para o desenvolvimento das competências" e, desse modo, tentaram explicitar o que buscavam por meio delas. Segundo o mesmo autor cada uma dessas competências era representada por 3 questões- uma fácil, uma média e uma difícil.

Com o passar do tempo e com a divulgação das estatísticas, percebemos que a competência que apresentou médias de desempenho mais baixas foi a III. Enfrentar situaçõesproblema. 
Em 2009, esse exame sofreu algumas alterações em sua estrutura, em seus objetivos e passou a servir como seleção para ingresso no Ensino Superior. Nessa nova versão, são 4 áreas avaliadas: Matemática, Linguagens, Ciências Humanas e Ciências da Natureza. Mas já no ano de 2009, pudemos perceber a nova tendência de resultados, dentre as quatro áreas avaliadas, a Matemática foi a que teve pior desempenho por parte dos alunos neste ano: $57,7 \%$ ficaram abaixo da média dos 500 pontos.

A Matemática ensinada em nossas escolas parece ser desprovida de significado. Pinheiro (2008) aponta para a mesma problemática, que perpassa outras disciplinas do currículo escolar e que tem como causa fatores além dos metodológicos.

\begin{abstract}
A escola tem um papel insubstituível quando se trata da formação das novas gerações para o enfrentamento das exigências postas pela sociedade contemporânea; o compromisso de reduzir a distância cada vez maior entre o formalismo da sala de aula e a cultura de base produzida no cotidiano deve ajudar os alunos a tornarem-se sujeitos pensantes, capazes de construir os elementos categoriais de compreensão e apropriação crítica da realidade. No entanto, o modelo encontrado é o de uma escola que se preocupa com a burocratização do ensino, com os conteúdos impostos pelos interesses de uma classe dominante e produzidos por uma política educacional fragmentada, desarticulada, descontínua e compartimentada. (PINHEIRO, 2008, p.11)
\end{abstract}

Salatino (2014) nos faz perceber como diversos fatores estão diretamente ligados à falta de significado que os alunos atribuem à escola. São fatores relacionados a pósmodernidade e ao capitalismo (papel da contenção da escola, valorização do consumo, inflação de títulos); ao desenvolvimento tecnológico (imediatismo, individualismo, prioridade de outros meios de socialização e não a escola) e à realidade brasileira (políticas públicas, formação de professores, desigualdade social, escola pública $\times$ privada).

Mas há também, como já mencionamos, fatores metodológicos que atrapalham o aprendizado significativo da Matemática na escola. Um deles é o método enciclopédico com que é ensinada e a fragmentação a que é submetida. Um único (e tão eficiente) resultado como o Teorema de Pitágoras seria suficiente para a obtenção da distância entre pontos da Geometria Analítica e da Relação Fundamental da Trigonometria. No entanto, cada um desses conhecimentos é ensinado separadamente, como um novo conhecimento que nada tem a ver com as ferramentas de que o aluno já dispõe.

A Análise Combinatória, tema com o qual trabalharemos nesta pesquisa, envolve raciocínios tão importantes e apresenta uma potencialidade imensa para a resolução de 
problemas, mas é mostrada na escola, muitas vezes, como um formulário a ser manipulado na resolução dos exercícios propostos.

Nesse trabalho, será apresentada uma perspectiva para o ensino de Matemática, baseada em trabalhos e ideias que vêm sugerindo um novo olhar para o ensino de Matemática, principalmente a Teoria das Situações de Guy Brousseau (1986). Essa teoria tem sido uma fonte de inspirações para novas abordagens da questão de um ensino de Matemática mais adequado à formação de um aluno crítico e reflexivo.

No Brasil, várias dissertações e teses da área de ensino têm abordado as ideias de Brousseau, bem como outras metodologias da chamada Didática Francesa da Matemática. Podemos citar como exemplo a dissertação de Azevedo (2008), na área do Ensino de Física. A autora, ao propor a implementação de novos conteúdos, não presentes no currículo tradicional, apresenta situações e as analisa do ponto de vista da Teoria das Situações e do Contrato Didático.

Pinheiro (2008) desenvolveu sua dissertação sobre Análise Combinatória a partir da resolução de problemas, utilizando também como referencial teórico a Teoria das Situações. Por estar relacionado ao mesmo conteúdo escolar que a presente dissertação e por ter uma excelente revisão bibliográfica, o trabalho de Pinheiro é de grande relevância nesta revisão bibliográfica, pois caminha paralelamente a esse, partindo inclusive da resolução de problemas para o estudo de Análise Combinatória.

Outras dissertações e teses, que utilizam o referencial da Teoria das Situações vêm sendo desenvolvidas na área de Educação Matemática no Brasil: Gonçalves (2010) fala sobre o raciocínio proporcional e as estratégias mobilizadas por alunos a partir de uma abordagem envolvendo a oralidade. Araujo (2010) mostra uma abordagem de circunferência e mediatriz em situações de aprendizagens, também baseado nestes referenciais.

Nesse trabalho, portanto, utilizaremos a ideia da situação adidática, um conceito da Teoria das Situações de Brousseau (1986), como ferramenta para uma aprendizagem matemática mais autônoma, ou seja, uma aprendizagem que possibilite o desenvolvimento de habilidades investigativas, interpretativas, críticas e criativas.

A Teoria das Situações é uma ferramenta de análise. Desse modo, a situação adidática é um conceito que permite modelar determinadas situações de aprendizagem a serem analisadas. Meu objetivo é mostrar que este conceito também serve como instrumento 
metodológico, à medida que o docente, de posse desse conceito, pode planejar situações potencialmente adidáticas em sala de aula.

Podemos, nessa introdução, ainda definir preliminarmente do que tratam as situações adidáticas, para uma melhor compreensão do que segue. Toda situação em que se aprende algo fora da escola, ou mesmo dentro da escola, mas sem uma intencionalidade direta de alguém para que se aprenda aquilo é considerada uma situação não didática. Por exemplo, quando se entende a regra de um jogo ou desenvolvem-se estratégias para vencê-lo. Por outro lado, quando há por trás da situação de aprendizagem uma intencionalidade do professor em ensinar algo, trata-se de uma situação didática.

A situação adidática é um caso especial de situação didática, que possui algumas características de uma situação não didática. Apesar da intencionalidade, bem como a coordenação e orientação de um professor, há nessa situação uma Sequência Didática que permite ao aluno aprender independentemente da presença desse professor. Ele vive experiências desafiadoras, procura respostas a perguntas que ele mesmo fez e tenta tirar conclusões, fazer generalizações e etc. Cabe ao aluno encontrar por si só a organização lógica do novo conhecimento. Cabe ao professor nessas situações, além de orientar a atividade, validar ou não o conhecimento elaborado pelo aluno.

Tendo em vista essa apresentação preliminar do que sejam situações adidáticas, pretendo com o presente trabalho alcançar o meu objetivo de analisar a validade das seguintes hipóteses:

- $\quad$ É possível formular situações potencialmente adidáticas.

- $\quad$ O conceito de situação adidática pode ser usado intencionalmente no momento do planejamento de ensino.

O trabalho pode fornecer elementos para responder outras questões de investigação, como: Que fatores contribuem ou impedem a existência de uma situação adidática? As situações adidáticas podem favorecer o aprendizado autônomo em Matemática? Elas podem contribuir para que os objetivos estabelecidos pelo PCN Ensino Médio sejam alcançados? Quais os impactos desse conceito na dinâmica de um sistema didático, cujos alunos estão 
acostumados com outro modelo de contrato $^{1}$ ? O que pensam professores em formação a respeito dessa proposta? Simultaneamente à inovação do ensino, podemos pensar numa inovação da própria formação inicial de professores?

Dividi o trabalho em três capítulos. O primeiro mostra o cenário teórico de nossas concepções e reflexões: uma breve caracterização da escola pública brasileira, com o objetivo de nos situarmos entre os desafios mais atuais; a concepção de desenvolvimento e aprendizagem de Vigotski, cuja teoria serve de base para as nossas concepções sobre o que é aprender, e em particular nos tem ajudado a compreender e trabalhar melhor com a própria teoria francesa; e finalmente a Teoria das Situações de Guy Brousseau, entre outros conceitos da Didática Francesa.

No segundo capítulo, encontram-se os referenciais metodológicos e o percurso desta pesquisa, passando pela escolha do tema, a elaboração da Sequência Didática e a aplicação dessa sequência em três momentos diferentes.

O terceiro capítulo mostra como foi a aplicação de nossa Sequência Didática em três diferentes situações, buscando sobretudo analisar a validade das hipóteses mencionadas.

\footnotetext{
${ }^{1}$ Contrato Didático segundo BROUSSEAU (1986)
} 


\section{Capítulo 1 - Referencial teórico}

Apresentamos, neste primeiro capítulo, alguns autores que contribuíram para que pudéssemos elaborar a presente pesquisa a fim de propor um modo de pensar o ensino da Matemática diverso do modo tradicional descrito na introdução. Dividimos este capítulo em três seções.

A primeira seção busca caracterizar o ensino público no Brasil a partir de um recente estudo etnográfico realizado em duas escolas paulistas, mas que analisa de forma abrangente, do ponto de vista social, cultural e econômico a realidade da escola pública brasileira na atualidade.

Essa seção, cercada de realismo, não pretende ser determinista. Apesar das dificuldades que o ensino brasileiro enfrenta, em decorrência dos muitos fatores que buscaremos sintetizar, precisamos acreditar em uma escola que leve os alunos a desenvolverem as habilidades que acreditamos serem relevantes.

De qualquer forma, o cenário realista deve estar sempre presente. Não podemos cair na fácil idealização das circunstâncias. As adversidades do meio em que se estabelece a educação são motivos para que se busque um ensino de qualidade, voltado para as questões atuais e para as características de nossos alunos reais.

Acredito que um trabalho de mestrado profissional em Ensino de Matemática, realizado em uma instituição pública, não poderia deixar de lado as questões que permeiam a realidade de nosso ensino público. Apesar de aplicarmos o projeto em uma escola pública diferenciada (a Escola de Aplicação da USP), é necessário deixar aqui registrado nosso interesse em contribuir para um ensino de Matemática de qualidade nas escolas públicas brasileiras, como um todo.

A segunda seção sintetiza as principais ideias do pensador bielorrusso Lev Vigotski (1896-1934) sobre o desenvolvimento e a aprendizagem a fim de fundamentar nossa concepção sobre esse tema. Pois são nossas concepções sobre o ensino e a aprendizagem que definem nossas práticas como professores.

Entre os principais conceitos de Vigotski destacamos a microgênese do desenvolvimento, a experiência pessoal, o meio e a intervenção pedagógica e a Zona de Desenvolvimento Proximal. 
Na terceira seção, abordamos alguns conceitos da Didática Francesa, em especial a Didática da Matemática de Brousseau, que inspirou o presente trabalho e a Sequência Didática que iremos apresentar. Essa teoria fornece conceitos práticos, relacionados diretamente com a rotina de uma sala de aula, entre eles o próprio conceito de situação adidática, tema do presente trabalho.

\subsection{Uma breve caracterização do ensino público no Brasil}

Temos observado um descaso por parte de toda a comunidade escolar com relação às aprendizagens e ao conhecimento. A escola, cada vez mais envolvida por seu papel de contenção ${ }^{2}$, tem deixado de lado o que deveria ser seu principal objetivo: proporcionar as aprendizagens e o desenvolvimento de certas competências aos alunos. Estes, por sua vez, deveriam ser os mais “interessados" pela aprendizagem, no entanto, em sua maioria, não são.

Apesar do foco deste trabalho estar na metodologia do professor e na sua preparação para a atividade docente, não queremos de modo algum responsabilizá-lo pelos problemas da educação, citados como justificativa para esse trabalho. Uma caracterização do ensino público do Brasil, e em nossa atualidade, faz-se necessária para evitar a culpabilização estrita de qualquer grupo específico pelos problemas do ensino que enfrentamos e também para contextualizar nossa proposta entre os desafios mais atuais e mais reais que nossa escola vem enfrentando.

Podemos perceber que os principais problemas da escola são, na verdade, reflexo do principal problema social do Brasil: a desigualdade. Comecemos pelo binômio público $\times$ privado. Com a massificação da escola pública no Brasil, houve uma tendência muito forte entre a classe dominante para matricular seus filhos em escolas particulares, as quais

\footnotetext{
${ }^{2}$ TIRAMONTI (2005) fala sobre o papel de contenção que a escola assume na pós-modernidade, pelo qual acaba assumindo funções até então atribuídas à família como as de proteção, atenção e orientação/transmissão de valores.
} 
cresceram sobremaneira. Hoje, de modo geral, atribui-se qualidade inferior à escola pública, responsável pela educação das classes populares ${ }^{3}$.

Para não pautar essa caracterização unicamente em minhas observações do ensino público e no senso-comum, no qual muitas vezes aparecem frases como "os alunos não estão interessados/motivados em aprender" ou "os professores estão despreparados para lidar com as demandas atuais", irei basear-me num estudo etnográfico feito recentemente por Salatino (2014), no qual se observam e analisam pontos importantes de nossa realidade escolar.

Salatino, primeiramente, nos revela um contexto social centrado no dinheiro, em que se destacam a valorização do consumo e da posse de determinados bens (como os tecnológicos), mesmo nas classes populares. Em meio a essas reflexões, o autor ressalta o cenário desigual em que a escola brasileira encontra-se inserida.

Os jovens das classes populares, desejosos de afirmação e de um maior reconhecimento individual, veem no longo processo de escolarização um atraso para ingressar no mercado de trabalho. Segundo o autor "os jovens experimentam nesse período a ausência de um sentido de caráter imediato e utilitário em seus estudos” (p.27).

Ao contrário do que pode parecer quando se diz "os alunos não estão interessados/motivados em aprender", esse desinteresse não tem a ver com dificuldade cognitiva ou uma simples falta de planejamento, mas com a dificuldade de construir um sentido positivo para a escola, por não verem nela possibilidades de ascensão social.

Sabemos que, apesar de a escola parecer a solução para as desigualdades, em nossa sociedade os títulos que distribui são mecanismos de seleção ("peneiras") que reproduzem essa desigualdade. No entanto, devido à massificação do ensino, muitos podem obter esses títulos, o que desloca as peneiras para um nível cada vez mais acima (formação técnica, superior etc.) ou para setores de educação não formal (cursos de inglês, informática, prévestibulares etc. $)^{4}$.

Isso reforça a desmotivação dos alunos perante a escola: seu certificado não é suficiente, pois existe oportunidade para todos na escola, mas não no mercado de trabalho. E

\footnotetext{
${ }^{3}$ Nesse trabalho, o nosso maior interesse está no ensino público brasileiro. Não nos limitamos, porém, a esse contexto para buscar respostas e pensar em estratégias metodológicas: utilizamos referências teóricas não nacionais e aplicamos uma Sequência Didática em duas escolas, uma delas particular e outra pública, mas muito diferenciada.
}

${ }^{4}$ Essa “inflação dos títulos" ou "translação do sistema de diplomas" é considerada por BOURDIER (1983) 
eles percebem isso, pois estão cercados de experiências parecidas: pessoas que terminaram o Ensino Médio, mas não alcançam boas oportunidades de emprego (ou mesmo a oportunidade de ingressar no Ensino Superior).

Daí a dificuldade de perceber a possibilidade de ascensão social através da escola. Mesmo os bons alunos, de acordo com o autor, não veem na escola suas possibilidades de formação para o mercado de trabalho e as buscam em outros cursos.

Há também uma desmotivação com relação aos conteúdos desenvolvidos na escola, muitas vezes desprovidos de utilidade prática. Salatino descreve mudanças em nossa sociedade capitalista que produzem uma cultura individualista, imediatista, consumista. Nessa sociedade em que se buscam a qualquer preço os prazeres imediatos, deseja-se também aprender apenas aquilo que será "usado".

Aluno L: Cara, (se corrigindo) professor, é muita conta pra pouca cabeça",
responde o aluno.
Professor: "L. você tem que por todo o seu caderno em ordem antes de falar
que é complicado". O aluno L. retruca: "Nóis vai usar no futuro?". "Vai
depender do Sr.", responde o professor.
Aluno G: "Vai depender do L.(ironicamente)... hoje em dia ninguém mais
quer trabalhar. Roubar tá mais fácil, a escola não dá mais futuro pra
ninguém". (SALATINO, 2014, p. 43)

A citação acima é feita como exemplo de alunos que se socializam contra a escola, ou seja, que se recusam a fazer as tarefas estipuladas pela escola, mas Salatino (2014) explica que a maioria dos alunos observados não se socializa nem contra nem pela escola, mas paralelamente à escola, tendo uma postura apática com relação ao conhecimento, apenas seguindo os rituais que lhes são impostos.

A escola termina por se tornar secundária em face de outros agentes de socialização, especialmente a mídia de massas, ou daqueles que marcam regulações de conduta (como a moda), a partir dos quais os jovens passam a buscar exemplos e grupos de referência para imitar. (SALATINO, 2014, p. 43)

As atividades incompletas, as cópias de exercícios sem a respectiva resolução, as faltas recorrentes evidenciam um descaso dos alunos, decorrente da inutilidade que atribuem à escola. Algumas atitudes dos alunos, quando muito frequentes, nos fazem pensar sobre a importância que eles atribuem ao conhecimento a ser produzido ou construído na escola. A pergunta "vale nota?" diante de uma atividade e a consulta (não permitida) à Internet ou aos 
colegas para obter respostas prontas revelam que não há um real interesse por parte dos alunos no conteúdo que a escola se propõe a ensinar.

Uma imagem que parece demonstrar a tensão dessa impossibilidade de construção de um sentido positivo para o trabalho escolar é a daqueles alunos que realizam a cópia, imersos muitas vezes em seus aparelhos celulares e ligados aos fones de ouvido. Suas músicas não parecem atrapalhá-los nessa atividade. Situação limítrofe, amálgama dessa tensão entre uma relação alienada com o saber, entre o estar ali e o estar alheio, ao mesmo tempo presente e ausente. (SALATINO, 2014, p. 31)

Por outro lado, algumas metodologias adotadas pelos professores também nos fazem pensar sobre o quanto eles acreditam na Educação. Na citação acima, vemos que é perfeitamente possível ao aluno conciliar sua atividade escolar com outras atividades extraescolares. Isso porque a atividade de cópia não exige dele nenhum raciocínio ou envolvimento do pensamento. A atividade de cópia, de um modo geral, reina na escola pública, o que demonstra certa indiferença também por parte dos professores. Veja o depoimento de Salatino (2014) sobre a escola estudada.

Se os estudantes têm consciência dessa característica é porque, revestidas dos mesmos procedimentos formais, a cópia aparece em diversas aulas, tanto nas de inglês, como também nas de matemática e física; e com menor frequência nas de sociologia. O ritual da cópia é na maioria das vezes realizado por completo - de enunciados, de explicações de conteúdos, de diversos temas, de fórmulas. (SALATINO, 2014, p. 46)

Acreditamos que a escrita de um modo geral deve ser sempre cultivada e valorizada na escola, pois envolve raciocínios e valores que lhe são próprios, porém limitar a ação da escrita estritamente à cópia limita também sua função à reprodução de símbolos, muitas vezes, nem lidos. Enfim, os alunos acabam sentindo falta de atividades em que participem mais ativamente e desenvolvem, inclusive, uma espécie de "preguiça de pensar e de argumentar". Além disso, o uso excessivo dessa "metodologia de cópia" transmite uma mensagem negativa do que se espera dos alunos, como se eles fossem capazes apenas de copiar.

Além de toda essa tensão enfrentada pela escola, há atualmente outro desafio, pois parece haver uma distância muito grande entre a juventude atual e a juventude da geração anterior, marcada pela evolução repentina dos objetos tecnológicos. Muitos professores não sabem o que fazer para controlar/usar/proibir o uso dos aparelhos tecnológicos que já estão 
presentes na sala de aula e que são usados "paralelamente" a escola, quando os alunos se socializam "paralelamente" à escola.

A culpabilização de determinado grupo é muito frequente na escola, como podemos perceber mesmo na dissertação supracitada. Para os professores, os alunos estão desmotivados. Para os alunos, os professores estão despreparados. Isso tudo, no entanto, não é o problema, é apenas a consequência de um sistema social, político e econômico, com o qual não devemos nos conformar, mas devemos conhecer. E conhecendo-o perguntar sempre: $\mathrm{O}$ que pode ser feito nesse cenário de contradições para enriquecer a formação dos professores e para despertar neles o desejo de lutar pela escola e acreditar nela? O que pode ser feito, diante de tantos fatores que levam os alunos a não atribuírem sentido para a escola, para que os mesmos sejam estimulados nas aulas?

Apesar das constatações de que há sim uma desmotivação dos alunos por razões que nem sempre são internas à escola, não podemos nos acomodar com isso e aceitar simplesmente o fato de que a maioria dos alunos não irá aprender. Acreditamos que um bom método, influenciado é claro por variados fatores de motivação, pode atrair mais alunos que outros ou atrair com maior qualidade.

Um desses fatores que influenciam na motivação dos alunos, o qual podemos extrair dos relatos de Salatino (2014) e de nossa própria observação do ensino e que merece destaque, é a expectativa do professor. Notamos que geralmente não há confiança no aluno e que muitas vezes o professor parte do pressuposto de que o aluno "não sabe nada" ou que "não quer aprender". Essa expectativa negativa é transmitida aos alunos implicitamente, como mostram as pesquisas ${ }^{5}$, de modo que eles mesmos percebem que pouco se espera deles.

Precisamos pensar num ensino de Matemática que leve em consideração todos os fatores apresentados nessa seção e inclusive a confiança de que todos são capazes de aprender, desde que suficientemente estimulados e convictos da importância de buscar esse aprendizado, não apenas para "melhorarem de vida" ou para "usarem Matemática em suas vidas", pois esses argumentos não são mais suficientes; um ensino cujo objetivo, sobretudo, seja a valorização do conhecimento e o prazer de aprender e raciocinar.

\footnotetext{
${ }^{5}$ ROSENTHAL, R.J.; JACOBSON, L. (1973) há mais de quatro décadas já nos mostram a influência da expectativa do professor no desempenho do aluno.
} 


\subsection{Uma teoria sobre a aprendizagem: Lev Vigotski}

Vigotski (1896-1934) foi um cientista bielo-russo que se destacou, entre outras coisas, no estudo da linguagem e do desenvolvimento. Suas obras foram reconhecidas no ocidente depois de sua morte, principalmente após a década de 60. É comum se estabelecer uma relação crítica entre suas obras e as obras do pensador suíço Piaget (1896-1980), pois este privilegia em seus estudos a maturação biológica, enquanto Vigotski, a interação social.

No entanto, as pesquisas desses dois autores em muito se complementam. Ambas consideram o sujeito como ser ativo de seu desenvolvimento e valorizam a sua interação com o meio, composto por objetos e outros indivíduos.

Apesar de a Didática Francesa estar explicitamente baseada nas ideias construtivista de Piaget, consideramos que alguns conceitos socioconstrutivistas de Vigotski, justamente pelo seu aporte social, explicam e embasam nossas concepções sobre o ensino e a aprendizagem e contribuem para fundamentar a nossa compreensão das teorias francesas da Didática da Matemática, e em particular a ideia de situações adidáticas.

A seguir, alguns conceitos de Vigotski relevantes para o presente trabalho.

\subsubsection{Microgênese do desenvolvimento}

De acordo com Jonnaert (1996, p. 128), Vigotski diferencia a aprendizagem escolar e o desenvolvimento intelectual do indivíduo, o que corresponde, respectivamente, ao tempo curto e ao tempo longo do desenvolvimento, os quais abordaremos na seção 1.3.5.

Em se tratando do segundo, há quatro planos de desenvolvimento a serem considerados: filogênese, ontogênese, sociogênese e microgênese. A filogênese é o plano do desenvolvimento da espécie humana, a qual determina alguns limites e possibilidades para o funcionamento psicológico do indivíduo. A ontogênese diz respeito ao caminho de desenvolvimento biológico pelo qual cada indivíduo da espécie humana passa e que determina fases, as quais também interferem no seu funcionamento psicológico. A sociogênese é o plano do desenvolvimento da cultura em que o indivíduo está inserido e que também determinam algumas características de seu desenvolvimento. 
Já a microgênese é o plano do desenvolvimento em que há menos determinismo, pois dois irmãos podem ter desenvolvimentos totalmente diferentes, mesmo fazendo parte da mesma espécie, da mesma família, da mesma cultura. Isso vai além do que um estudo filogenético, ontogenético ou sociogenético pode explicar. As histórias individuais são diferentes. Cada experiência vivida faz diferença no desenvolvimento e a esse plano de acontecimentos chamamos microgênese.

É no plano da microgênese que estão inseridas as atividades escolares, as quais irão interferir no desenvolvimento do aluno desde que se tornem de fato experiências pessoais como veremos no tópico a seguir.

A microgênese chama nossa atenção para as singularidades e a heterogeneidade, que não podem ser desprezadas quando tratamos de aprendizagem. Devemos considerar que cada aluno tem seu próprio modo de encarar os problemas e resolvê-los de acordo com as experiências que já teve e o nível de desenvolvimento em que se encontra.

\subsubsection{Experiência pessoal}

Segundo Vigotski, ninguém exerce influência imediata nem mesmo transforma o outro. "Vimos que o único educador capaz de formar novas reações no organismo é a sua própria experiência. Só aquela relação que ele adquiriu na experiência pessoal permanece efetiva para ele" (Vigotski, 2010, p. 63).

Apenas a experiência da própria pessoa modifica suas reações inatas e, desse modo, conhecimento que não passou pela experiência pessoal não pode ser considerado conhecimento. $\mathrm{O}$ autor não aceita a passividade no processo educacional, pois a educação deve se basear na atividade do aluno e o professor deve ser um orientador dessa atividade.

“A educação deve ser organizada de tal forma que não se eduque o aluno, mas o próprio aluno se eduque.” (Vigotski, 2010, p.64) Essa é justamente a nossa proposta, ao defender o uso de situações adidáticas no ensino de Matemática, pois essas situações valorizam a experiência pessoal de cada educando, como sendo esta a responsável direta pelo aprendizado. 


\subsubsection{Meio social e intervenção pedagógica}

Apesar de valorizar a experiência pessoal como relatado anteriormente, para Vigostski, "o meio social é a verdadeira alavanca do processo educacional e todo o papel do mestre consiste em direcionar essa alavanca" (2010, p. 65). Para Vigostki, então, a intervenção intencional na aprendizagem, isto é, a intervenção pedagógica é essencial para o desenvolvimento do indivíduo.

A seguinte comparação é esclarecedora da relação existente entre a experiência pessoal, o meio social e a intervenção pedagógica: ele compara o ofício do mestre ao do jardineiro, que não pode agir diretamente no crescimento da planta, mas indiretamente. Assim como o jardineiro atua no meio em que está a planta (rega, aduba, poda), para que o meio ofereça condições de crescimento para a mesma, o professor atua no meio em que está inserido o aluno para propiciar o seu desenvolvimento.

Nessa concepção, assim como para Brousseau (1986), o meio é ativo na educação e também, por fazerem parte dele, o próprio aluno, o mestre e todos os objetos presentes no ambiente de ensino.

Percebemos que só faz sentido pensar numa situação adidática quando se tem em mente essa concepção, pois a situação adidática é consequência de uma preparação do meio com uma intencionalidade pedagógica de que o aluno se aproprie das propriedades do novo conceito e desenvolva-se.

\subsubsection{Zona de Desenvolvimento Proximal}

Um conceito muito conhecido de Vigotski é a Zona de Desenvolvimento Proximal (ZDP), que na escala do desenvolvimento cognitivo, é a área definida entre o nível real de desenvolvimento e o nível potencial da criança.

O nível real de desenvolvimento envolve aquilo que ela já sabe ou é capaz de realizar sozinha. O nível potencial envolve tudo o que está em vias de aprender. Temos indícios do nível potencial de cada criança nas atividades que, apesar de não realizar ainda autonomamente, é capaz de realizar com o auxilio de outra pessoa mais experiente. 
A ZDP é, então, o estágio que pode vir a ser alcançado pela criança no nível de desenvolvimento em que se encontra. Conhecer a ZDP de cada indivíduo seria indispensável, já que apenas nessa área do desenvolvimento a intervenção educativa se tornaria útil ou eficiente. No entanto, a ZDP não pode ser medida ou testada experimentalmente. Cada tópico, para cada indivíduo, em cada instante, encontra-se em um nível diferente de desenvolvimento. Desse modo, a ZDP é um conceito complexo e flexível que apenas instrumentaliza nosso pensamento.

A ideia de ZDP nos faz ter uma visão prospectiva do conhecimento, isto é, valorizarmos o que o aluno pode ainda aprender e não olharmos apenas para o que ele sabe ou não, para o que ele já é capaz ou não é capaz de fazer, pois é nas possibilidades que reside a ação educacional.

Esse conceito faz-nos pensar também que trabalhar no nível de desenvolvimento real da criança é inútil, já que não a fará prosseguir em seu desenvolvimento. Trabalhar em um nível de desenvolvimento potencial, distante da ZDP é igualmente inútil, pois a criança não conseguirá acessá-lo.

Lembrando que Vigotski sempre priorizou o desenvolvimento interpsicológico, podemos considerar também que, para o autor, a interação com os outros é significativa quando faz seguir o desenvolvimento, quando faz despertar funções que estão na Zona de Desenvolvimento Proximal.

Esse conceito também faz parte da concepção de desenvolvimento e aprendizagem que adotamos. Ao permitir que os alunos trabalhem com seus pares, em uma situação potencialmente adidática, o professor assume que o desenvolvimento pode prosseguir através da diversidade de ZDPs que existe em uma sala de aula, cuja turma é heterogênea.

\subsection{A Didática da Matemática: contribuições francesas}

A Didática Francesa, em especial a Didática da Matemática de Brousseau inspiraram o presente trabalho, por fornecer conceitos teóricos com fins práticos, os quais podem ser relacionados diretamente com a rotina de uma sala de aula. 
A seguir, os principais conceitos da Didática Francesa que cercam a ideia de situação adidática, a qual propomos aqui como instrumento metodológico para o professor de Matemática.

\subsubsection{Sistema didático}

Antes de tudo, devemos nos localizar espacialmente. Estamos tratando neste trabalho de um ambiente específico, que, apesar de apresentar formatos diversificados ao longo da história e nas várias regiões do mundo em que se faz presente, apresenta também características específicas e objetos bem determinados: a sala de aula.

Desse modo, fica claro que estamos considerando o ensino formal e direcionando nossos pensamentos e análises à relação didática formal que ocorre no interior da sala de aula, bem como ao processo de planejamento, que tem como fim a relação didática.

Referiremo-nos à sala de aula como um sistema didático e não a consideraremos isolada. Sabemos que a realidade de uma sala de aula reflete as tensões, as concepções e os valores da comunidade em que está localizada.

Chevallard (1991) define como sistema didático aquele que contém o professor (P), os alunos (A), o saber ${ }^{6}(\mathrm{~S})$ a ser ensinado e suas relações. Para ele, faz-se necessário esclarecer o funcionamento desse sistema de acordo com as características de cada um dos três polos, levando-se em conta sua relação com o mundo exterior.

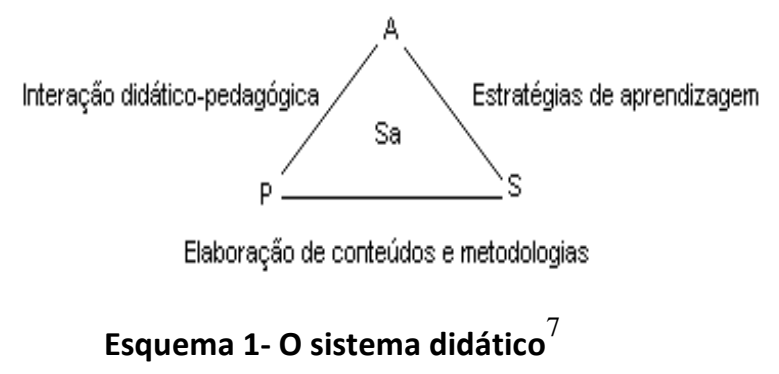

\footnotetext{
${ }^{6}$ PAIS (2002, p. 36) diferencia os termos conhecimento e saber, quando trata da teoria da Transposição Didática de CHEVALLARD. O primeiro tem caráter mais subjetivo, enquanto o segundo, cujo uso torna-se adequado neste texto, caracteriza a produção de uma área disciplinar, podendo ser chamado de saber de referência. Entre autores que se referem à Didática Francesa, portanto, usam-se esses dois termos com sentidos contrários do que usamos naturalmente em nosso idioma.

${ }^{7}$ Adaptado de ASTOLFI et al. (1997, p.72)
} 
Pode-se criticar esse esquema pelo reducionismo que carrega. No entanto, se considerarmos os três elementos representados como famílias de variáveis que se interrelacionam num processo de ensino e aprendizagem, como ressalta Jonnaert (1996, p. 121) teremos um modelo fecundo para as demais teorias didáticas.

O elemento Professor traz embutidas as variáveis de sua formação e crenças. O elemento aluno, que possui certa ambiguidade, pois pode ser considerado como o grupo de alunos ou como cada aluno em suas particularidades, representa um espectro de variáveis do ensino. O saber a ser ensinado, por sua vez, produto da Transposição Didática ${ }^{8}$, pode assumir várias formas, dependendo de como se dá esse processo. A situação de aprendizagem (Sa), representadas no interior do esquema 01 , também é uma criação didática, pois não se dá naturalmente.

Num sistema didático, há outros elementos secundários como objetivos, métodos e recursos didáticos. No entanto, como já foi dito, professor, aluno e saber polarizam as principais variáveis do sistema.

Chamam-se relações didáticas as trocas organizadas entre esses três elementos. Essas relações são assimétricas, na medida em que as relações com os saberes são subjetivas. $O$ professor mantém uma relação com o saber, enquanto o aluno mantém outro tipo de relação, a relação com o saber varia mesmo entre os próprios alunos. Essa assimetria é a característica fundamental das relações didáticas. E a função da relação didática é de fazer evoluir a relação com os saberes, como explica Jonnaert (1996, p. 123).

As relações didáticas podem ser compreendidas como um jogo em que há mudanças de papéis constantes. Sobre isso, veremos adiante o conceito de devolução e contra devolução.

Para Jonnaert (1996, p. 125), as “múltiplas relações com os saberes, mas, sobretudo sua instabilidade e sua movimentação no interior da relação didática, constituem o principal motor desta última".

\footnotetext{
${ }^{8}$ Conceito atribuído a CHEVALLARD (1991).
} 


\subsubsection{Teoria das Situações}

Guy Brousseau, nascido em 1933 em Taza, Marrocos, mostrou desde cedo seu interesse por estudar Matemática. Em 1953 tornou-se professor e em 1964 criou o Centro de Pesquisa do Ensino de Matemática no Centro Regional de Documentação Pedagógica de Bordeaux, para criar materiais e pesquisas para o ensino de Matemática.

Em 1970, Brousseau comunicou pela primeira vez a Teoria das Situações, que já elaborava há anos, e lançou os alicerces para o desenvolvimento da disciplina científica "Didática da Matemática".

Brousseau baseou-se não apenas em teorias, como as de Piaget e Bachelard, mas também na análise de sua própria experiência docente para propor sua teoria. No Brasil, as obras de Brousseau passaram a ser conhecidas nos anos 90 e hoje são largamente utilizadas pelos pesquisadores brasileiros da educação.

Podemos entender por situação didática o conjunto das múltiplas relações entre os três elementos principais de um sistema didático - professor, aluno e saber. Uma situação didática ocorre somente quando há relação entre esses três elementos.

Vale observar que em uma sala de aula é possível que haja momentos em que só dois desses elementos se relacionem. Essas situações, no entanto, não serão chamadas de situações didáticas.

Uma situação é caracterizada em uma instituição por um conjunto de relações e de papéis recíprocos de um ou vários sujeitos (aluno, professor, etc.) com um meio, visando à transformação deste meio segundo um projeto. O meio é constituído por objetos (físicos, culturais, sociais, humanos) com os quais o sujeito interage em uma situação. (BROUSSEAU, 1998, p.2)

Brousseau utiliza o termo Milieu para referir-se ao meio (ambiente ou entorno) que interage com o aluno. Esse meio produz incertezas, contradições, atitudes e emoções que levam à aprendizagem.

Pode-se observar, como um dos principais princípios em que se baseia a Teoria das Situações, a necessidade de especificar a área do conhecimento estudada pela Didática, pois cada saber tem a sua especificidade que deve ser considerada. 
Desse modo, apesar de ser usada em estudos de outras áreas, a Teoria das Situações Didáticas foi desenvolvida para descrever o processo de ensino e aprendizagem em Matemática.

Outro princípio, em que se baseia a Teoria das Situações, é a diferença (apesar das proximidades) entre a atividade do matemático e do professor de Matemática. Enquanto o primeiro deve buscar a generalização, isto é, conteúdos desprendidos de um contexto específico, o professor deve fazer o contrário, trazer o conteúdo para um contexto significativo para o aluno, aproximar o conhecimento em jogo do conjunto de saberes que o aluno já tem.

Há ainda, entre os princípios da Teoria das Situações, a necessidade de fortalecer a relação direta entre o aluno e o conhecimento e é desse princípio que surge o conceito de situações adidáticas.

\section{$\underline{\text { Situações adidáticas }}$}

O fim de qualquer situação didática é a possibilidade de interação livre do aluno com o meio não didático. Não se pode dizer que o aluno aprendeu um conceito se ele não for capaz de utilizá-lo fora do contexto de ensino e sem nenhuma indicação intencional. Portanto, situações com características não-didáticas precisam ser produzidas intencionalmente na escola, é o que estamos chamando de situações adidáticas.

Um "meio adidático" é a imagem na relação didática do meio exterior ao ensino em si, ou seja, desprovido de intenções e pressupostos didáticos. Esse meio é denominado adidático, pois considera o funcionamento normal dos conhecimentos, fora das condições didáticas (aquelas em que alguém decidiu pelo aluno que saber ele deveria aprender). (BROUSSEAU, 2008, p. 89)

As situações ideais são aquelas em que o professor seleciona problemas adequados para que o aluno atue, reflita e evolua, problemas que provoquem a mobilização ${ }^{9}$ dos saberes já adquiridos. Toda a atividade deveria ser planejada para direcionar o aluno a uma situação adidática.

\footnotetext{
${ }^{9}$ PERRENOUD (1999), ao discutir a noção de competência, valoriza o conceito de mobilização de recursos cognitivos. Ele considera a metáfora de mobilização mais adequada que a de transferência de saberes, justamente por destacar o papel ativo do sujeito.
} 
Diz-se que uma situação é didática quando predomina o controle do professor sobre a atividade. Já a situação adidática ocorre quando o aluno trabalha de forma autônoma. Apesar da intencionalidade didática do professor sobre a tarefa, sua interferência direta na aprendizagem não ocorre.

Quando o aluno se torna capaz de pôr em funcionamento e utilizar por si mesmo o saber que está construindo, em situação não prevista em qualquer contexto de ensino e também na ausência de qualquer professor, está ocorrendo então o que pode ser chamado de situação adidática. (BROUSSEAU, apud PAIS 2002, p.68)

É importante ressaltar que as relações dos sujeitos do sistema didático com o saber são distintas e que não existe uma única maneira de apropriar-se de um saber. É um desvio querer impor aos alunos uma forma única de compreender um conceito. As situações adidáticas podem amenizar esse desvio.

Ressaltamos ainda que não estamos propondo, de maneira alguma, a exclusividade de situações adidáticas. Entendemos que, sob a responsabilidade de cada professor, na atividade cotidiana acaba-se por fazer uso de ambas as formas de situações. O ideal seria, então, buscar certo equilíbrio entre situações didáticas e adidáticas.

\section{$\underline{\text { As quatro fases da situação }}$}

As situações adidáticas numa aula de Matemática, de acordo com Brousseau (2008, p. 27-32) ocorrem em quatro etapas: ação, formulação, validação e institucionalização.

Situações de ação - caracterizadas pelo aspecto experimental do conhecimento, pelas tentativas e, frequentemente, pela ausência de argumentação. Quando o aluno tem em mente uma estratégia para resolver uma situação, mas não é capaz de verbalizá-la, a situação vivenciada é de ação. Na situação de ação prevalece a intuição, o raciocínio implícito.

Situações de formulação - o aluno já faz afirmações sobre a sua resolução, mas sem questionar ou justificar a sua validade. É quando num jogo, por exemplo, a equipe percebe e comunica estratégias de sucesso, mas sem compreender o porquê delas.

Situações de validação - já aparecem mecanismos de prova, a necessidade de validar aquilo que se afirma, mas sem o rigor matemático. Nessa etapa, procura-se convencer o outro sobre a validade de uma regra ou estratégia e os próprios critérios de validação, por vezes, são questionados. 
Situações de institucionalização - nesta etapa o conhecimento se torna objetivo e universal. Enquanto as três primeiras etapas podem caracterizar situações adidáticas, esta quarta etapa é de natureza didática, pois cabe ao professor reforçar e generalizar o conhecimento adquirido. Brousseau inseriu essa quarta etapa das situações posteriormente, pois percebeu que existe a necessidade de o professor conferir um status aos eventos vistos, até a terceira etapa, como resultados locais da sala de aula.

\section{$\underline{\text { A estruturação do meio }}$}

Mas quem é o professor e quem é o aluno de que tratamos? O esquema 2 nos mostra os múltiplos papéis que professor e alunos desempenham no interior de um sistema didático.

Em 1986, Brousseau introduziu um novo conceito na Teoria das Situações, a estruturação do meio, que decorre do fato de as posições do professor e do aluno variarem de acordo com a posição do observador.

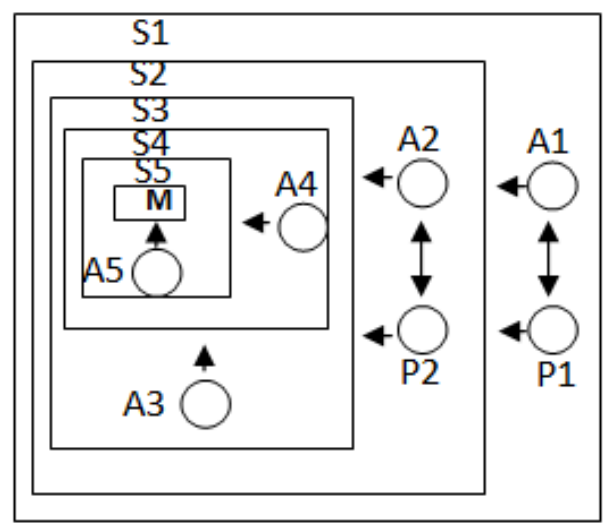

Esquema 2- A estruturação do meio ${ }^{10}$

A1, A2, A3, A4 e A5 representam as cinco posições que o "aluno" pode assumir em uma análise, dependendo de sua interação com os meios, que constituem o âmbito da situação. P1 e P2 são as posições do professor. S1, S2, S3, S4 e S5 são os níveis de situação em que ambos, aluno e professor, desempenham seus papéis. M é o meio material e as flechas indicam que o aluno/ professor atua sobre.

\footnotetext{
${ }^{10}$ Adaptado de BROUSSEAU, G.(2008, p.57 )
} 


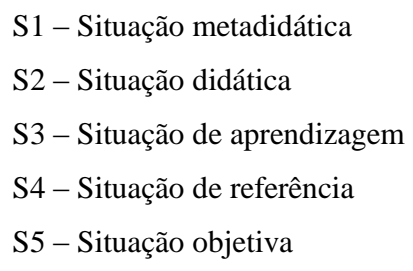

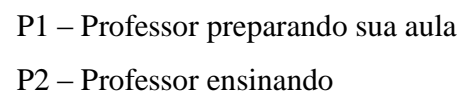

Vamos observar o esquema de dentro para fora. M representa o meio material, ele é constituído pelos objetos materiais e as regras que determinam o fracasso ou sucesso de uma atividade. $\mathrm{O}$ aluno, na posição de ator objetivo, interage diretamente com esse meio.

$\mathrm{O}$ ator objetivo e o meio material constituem a situação objetiva, que se torna em meio objetivo, efetivo ou fictício, para A4, o sujeito que atua. Este se imagina na situação de ator objetivo e é capaz de representá-lo e analisá-lo.

O sujeito que atua e o meio objetivo encontram-se na situação de referência, que, por sua vez, é o meio de referência para A3, o sujeito da aprendizagem. A reflexão sobre a sua ação é fundamental para a aprendizagem de A3.

A situação de aprendizagem, constituída pelo sujeito da aprendizagem e o meio de referência, é o centro de toda estruturação do meio, é onde reside o verdadeiro sentido das situações. Professor e aluno administram juntos a situação de aprendizagem e, fazendo isso, eles são, respectivamente, P2 (o professor que ensina) e A2 (o aluno genérico).

P2, A2, as situações de aprendizagem e as interações entre esses três elementos constituem as situações didáticas.

As situações didáticas são meios didáticos para o professor, como P1 (o professor que prepara sua aula), que numa situação metadidática, analisa e planeja situações didáticas.

É interessante notar, nesse esquema, que o professor que prepara sua aula está diretamente relacionado com um sujeito universal e uma situação didática e o professor que ensina está diretamente relacionado com um aluno genérico e com uma situação de aprendizagem, mas em nenhum momento o professor está diretamente relacionado ao sujeito da aprendizagem. Esse esquema, então, não deixa brechas para se pensar numa "transmissão de conhecimento".

É importante notar também, que os níveis de interação são dimensões de um mesmo acontecimento, e por dividir o mesmo espaço e tempo, influenciam um ao outro. 


\subsubsection{Contrato Didático}

Um dos principais elementos da Teoria das Situações Didáticas, o Contato Didático é um termo que vem sendo incorporado cada vez mais aos discursos educacionais pela sua pertinência e relevância para a educação. O Contrato Didático é, na verdade, uma metáfora, cujo significado esclarece a relação existente entre os três elementos de um sistema didático: o professor, o aluno e o saber escolar.

A noção de Contrato Didático de Brousseau está relacionada com as noções de Contrato Social de 1762, proposto por Rousseau, e de Contrato Pedagógico de 1974, proposto por Filloux.

Sempre existe um Contrato Didático estabelecido no interior de um sistema didático, ele abrange as regras e expectativas dos sujeitos envolvidos (professor e alunos) com relação a outros sujeitos e com relação ao objeto (saber). Esse contrato pode ser explícito, mas é, em sua maior parte, implícito.

Fazem parte das expectativas do aluno, com relação ao professor, por exemplo, o modo de articular os conceitos, os tipos de tarefa que cobra e as exigências que faz. É regra do contrato, segundo Jonnaert (1996), cada relação privada com os saberes em jogo.

Algumas características do Contrato Didático:

- $\quad$ Ele é único. Em cada sistema didático, há um contrato que é único e depende exatamente dos espectros de variáveis que são o professor, o aluno e o saber.

- $\quad$ Ele é perecível. Isso quer dizer que tem um período de validade determinado, isto é, o tempo que durar a relação didática.

- Ele é dinâmico e flexível. Nenhum dos elementos do sistema didático é estático, além disso, as relações didáticas estão sempre evoluindo. Isso confere ao contrato um caráter dinâmico. Para Jonnaert (1996), se o sistema de regras do Contrato Didático for rígido e imutável, paralisará cada um num papel único e nenhuma aprendizagem será possível. Para Pais (2002, p. 87), um contrato fechado pode parecer comodismo e alienação.

- $\quad$ Ele é implícito, apesar de se tornar explícito, sobretudo em casos de ruptura, ou seja, quando o processo de ensino e aprendizagem é obstruído por algum acontecimento não previsto no Contrato Didático. 
É importante reiterar, sobre a parte do professor no contrato, que ele não pode desempenhar pelo aluno o seu papel de aprender, pois os projetos (de ensinar, de aprender) são pessoais e intransferíveis. No entanto, não pode ausentar-se da responsabilidade de arquitetar e construir meios adequados para o desenvolvimento da aprendizagem. A pergunta que fica, então, é: Até que ponto o professor pode responsabilizar-se pelos efeitos de seu projeto nos projetos de seus alunos?

Para responder essa questão, Brousseau refere-se a níveis de contrato, de acordo com o grau de responsabilidade e influência do emissor no projeto dos receptores. São eles:

- $\quad$ O contrato de emissão: É modelo típico de um programa de rádio ou televisão. O emissor não está preocupado com a formação dos receptores. "E se o receptor, por sua vez, modifica suas crenças ou atos, de alguma maneira o faz independente da vontade do emissor, e não segundo seu projeto" (BROUSSEAU, 2008, p. 60). É possível que esse contrato se desenvolva numa sala de aula, quando o professor não considera o feixe de variáveis que é o polo aluno do sistema didático.

- $\quad$ O contrato de comunicação: Nesse caso, apenas o formato da mensagem muda: o emissor preocupa-se com o vocabulário utilizado para garantir a chegada da mensagem ao receptor, e pode chegar a repetir a mensagem de um modo mais simples a pedido do receptor.

- O contrato de habilidade: O emissor preocupa-se com a aceitação dos receptores e garante a validade da mensagem, ainda que sem o rigor das demonstrações matemáticas. Desse modo, demonstra maior interação com o saber e com os alunos.

- $\quad$ A produção de um novo saber: A mensagem do emissor é inédita e original para os receptores e há preocupação com a validade da mensagem. Para Brousseau, há ainda outros níveis, mas o ideal é que o aluno exerça controle sobre seu instrutor, demonstrando até que ponto as mensagens lhe são relevantes (novas), compreensíveis e aceitáveis.

Pais (2002, p. 82) refere-se a três tipos de Contrato Didático:

- $\quad$ Enfase na relação do saber - professor: neste caso, a participação do aluno nas situações é mínima. O professor detém o monopólio do saber e cabe a ele trazer problemas, opiniões e explicações. Ao aluno cabe prestar atenção, copiar, repetir os exercícios, estudar e fazer provas.

- $\quad$ Enfase na relação saber - aluno sem controle do professor: a supervalorização da relação direta do aluno com o saber, no outro extremo do tópico anterior, joga para o aluno toda a responsabilidade do processo de aprendizagem como se essa fosse espontânea. 
- $\quad$ Enfase na relação saber-aluno com controle do professor: o compromisso do professor com o processo de ensino e aprendizagem reflete em seu planejamento em suas intervenções. Situações desafiadoras, problemas, jogos são escolhidos cuidadosamente, considerando-se os referenciais extraescolares que o aluno tem.

\subsubsection{Devolução}

Brousseau (2008) considera a devolução como o componente essencial do Contrato Didático. Dela depende o surgimento de uma situação adidática. O termo "Devolução" foi emprestado da terminologia legal da França. De acordo com BROUSSEAU (1996, p. 51), “devolução era um ato pelo qual o rei- por direito divino - abandonava seu poder para remetêlo a uma câmara.”

A devolução didática é, de igual modo, a transferência da responsabilidade pelo resultado de uma situação. Quando o aluno toma o problema como seu e assume a responsabilidade sobre a sua resolução para dar prosseguimento à situação adidática, diz-se que o professor realizou a devolução e o aluno a aceitou.

Apenas havendo a devolução, o aluno se empenhará no entendimento do problema. Apenas havendo a devolução, o aluno se sentirá motivado e/ou desafiado a buscar sua solução.

A ocorrência da devolução depende de muitas variáveis relacionadas ao Contrato Didático, à origem do problema e a fatores de ordem afetiva e social. Ela caracteriza o início de uma situação adidática e é indispensável para que a situação promova aprendizagem.

Caso ocorra a devolução, o próprio aluno será responsável por fazer as perguntas certas e buscar, para ela, respostas, o que caracteriza uma situação adidática, menos artificial do que costumam ser as perguntas que demonstram explicitamente a intencionalidade didática. O grande paradoxo da devolução é o seguinte: o professor não pode aceitar a resposta errada para um problema, no entanto, se der a resposta correta, a situação deixará de ser adidática e a responsabilidade pelo problema deixará de pertencer ao aluno.

Jogando a regra da devolução, o professor pode exigir do aluno que tome por ele mesmo o ritmo da aprendizagem. Mas, isso não é suficiente. Se ele é bloqueado na situação que o professor lhe propõe e que não pode mais avançar em seu próprio ritmo de aprendizagem, por sua vez, o aluno tem o 
direito (volta a deter) de reclamar ao professor em retomar uma de suas funções em aplicar uma outra regra do jogo que essa da devolução. $\mathrm{O}$ aluno deve poder contra-devolver o papel de cada um, aluno e professor, na organização da evolução do saber no interior da relação didática (JONNAERT, 1996, p.7)

O aluno pode sentir-se bloqueado na solução do problema e não conseguir avançar, isso o leva a realizar a contra devolução, isto é, devolver novamente ao professor a responsabilidade pela resolução daquele problema.

\subsubsection{Escalas temporais}

Jonnaert (1996, p. 125) apresenta uma dupla escala temporal, definida por Gérard Vergnaud, para a aquisição do saber (veja a nota de rodapé 6 da página 18). Simultaneamente, o aluno vivencia a escala temporal curta, em que ocorrem novas situações sucessivas, pautadas pela relação didática e o tempo longo da psicogênese do conhecimento, que se desenvolve além da relação didática.

Considerando a escala curta, podemos dizer que as relações entre os três elementos do sistema didático evoluem continuamente. Inicia-se na ausência da relação direta entre aluno e saber. O professor, inicialmente, parece ser o único que tem o "poder" de interagir com o saber. Com o passar do tempo, os laços que unem aluno e saber devem ser reforçados para que, futuramente, na ausência de uma relação didática, o aluno seja capaz de interagir diretamente com ele. Observe o esquema:

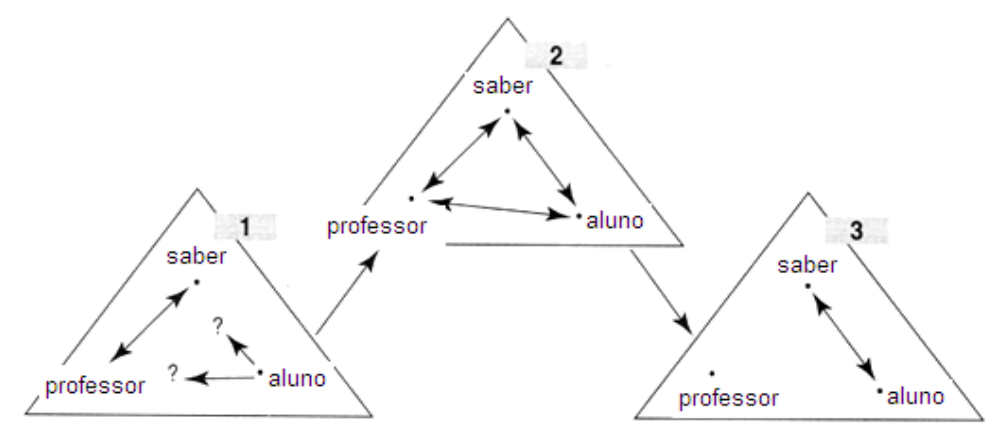

Esquema 3- As relações assimétricas com os saberes ${ }^{11}$

\footnotetext{
${ }^{11}$ Os esquemas 03, 04 e 05 são adaptados de JONNAERT, P. (1996, p. 123, 126 e 131)
} 
A aquisição do conhecimento na escala do tempo curto está submetida às cláusulas do Contrato Didático e às regras de uma relação didática de uma maneira geral, bem como ao tempo escolar, que impõe com o currículo o tempo em que deve ocorrer cada aprendizagem.

Para Jonnaert (1996, p. 116), “a relação didática é precária, mas ela possui o objetivo de desenvolver em cada aluno um processo em longo tempo de construção do conhecimento".

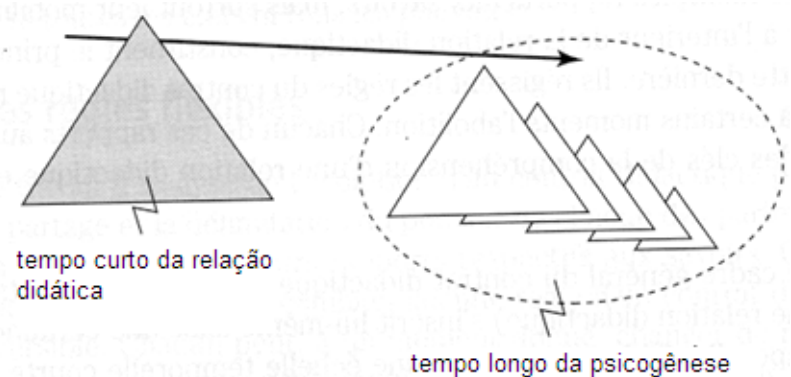

da aquisição do conhecimento

Esquema 4- A dupla dimensão temporal da relação didática

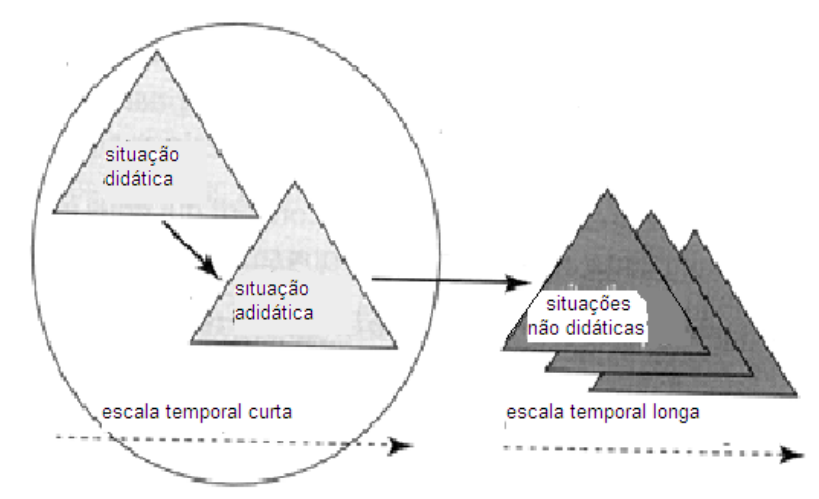

Esquema 5- Em direção a uma situação não didática

As situações didáticas e adidáticas ocorrem no tempo curto, mas estas últimas devem garantir a preparação do aluno para relacionar-se com o saber no tempo longo, no qual não haverá a figura do professor, mas apenas do indivíduo, relacionando-se diretamente com o conhecimento.

São as situações adidáticas que, de fato, oportunizam ao aluno uma aprendizagem autêntica e a confiança necessária para utilizar as ferramentas matemáticas, aprendidas na escola, em situações que estão fora do alcance das relações didáticas. 


\section{Capítulo 2 - Metodologia}

Neste capítulo, iremos descrever nosso percurso metodológico buscando justificar cada uma das escolhas realizadas na presente pesquisa.

\subsection{Planejamento da pesquisa}

A constatação dos baixos resultados que a prática do ensino de Matemática, no Brasil, tem demonstrado nas avaliações nacionais e internacionais e a crença de que esses resultados são sintomas, entre outras coisas, de uma anomalia no ensino me levaram a estudar a Teoria das Situações, refletir sobre a importância das situações adidáticas no ensino e desenvolver o seguinte projeto: implementação e análise de uma situação potencialmente adidática. Para isso, eu deveria seguir os seguintes passos:

$1^{o}$ passo - Estudar a Teoria das Situações com um foco maior sobre as situações adidáticas;

$2^{o}$ passo - Com base nesses estudos, elaborar uma Sequência Didática, potencialmente adidática;

$3^{o}$ passo - Implementar essa sequência em uma ou mais escolas reais, com base nos referenciais metodológicos adotados;

$4^{o}$ passo - Analisar os resultados da implementação da sequência, norteados pelos referenciais teóricos e pelos objetivos, especificados anteriormente.

Antes mesmo de ingressar no Programa de Mestrado Profissional em Ensino de Matemática do IME-USP, Instituto de Matemática e Estatística da USP, parte do primeiro passo já havia sido realizada, motivada por um curso ${ }^{12}$ que realizei. Nesse mesmo curso, havia construído uma Sequência Didática potencialmente adidática sobre Análise Combinatória (o $2^{\circ}$ passo). Havia também aplicado essa sequência durante minhas pesquisas e em minha atividade docente, havendo registros dessas aplicações, ( $3^{\circ}$ passo).

\footnotetext{
${ }^{12}$ Disciplina de pós-graduação Fundamentos das Ciências Experimentais e Implicações para o EnsinoAprendizagem, ministrada pelos professores Elio Carlos Ricardo e Mauricio Pietrocola Pinto de Oliveira, realizada em 2009 - meu primeiro contato com a Didática da Matemática.
} 
Durante o Mestrado, então, me aprofundei nas pesquisas (reforçando o $1^{\circ}$ passo), e reapliquei a Sequência Didática ( $3^{\circ}$ passo) para iniciar a fase principal, e até então não começada, de análise ( $4^{\circ}$ passo).

\section{Definindo Sequência Didática}

Para Zabala (1998, p. 18), Sequência Didática é "um conjunto de atividades ordenadas, estruturadas e articuladas para a realização de certos objetivos educacionais, que têm um princípio e um fim conhecidos tanto pelos professores como pelos alunos".

De acordo com esse autor, a Sequência Didática deve considerar:

- conhecimentos prévios;

- $\quad$ significância e funcionalidade dos novos conteúdos;

- $\quad$ nível de desenvolvimento;

- Zona de Desenvolvimento Proximal;

- $\quad$ conflito cognitivo e atividade mental;

- $\quad$ atitude favorável;

- $\quad$ auto-estima e autoconceito;

- $\quad$ aprender a aprender.

Nota-se que entre os itens apontados está a Zona de Desenvolvimento Proximal, conceito que abordamos na seção 1.2.4, entre as principais ideias de Vigotski que embasam o presente trabalho.

Nossa sequência precisaria considerar estes princípios, bem como outros enfatizados em nossos referenciais teóricos e metodológicos, e ainda mostrar potencial em seu caráter adidático.

\section{$\underline{\text { Projetando uma Sequência Didática }}$}

De acordo com Machado (2000, p. 7), “a capacidade de projetar pode ser identificada como o traço mais característico da atividade humana". Para o autor, são três as principais propriedades de projeto, que o definem:

- $\quad$ Refere-se a um futuro possível e desejável, cuja realização depende de metas e ações que se desenvolvem no presente. 
- $\quad$ É indeterminado, pois sua concretização envolve diversas variáveis que podem proporcionar uma rede de resultados diferentes. No entanto, algumas certezas devem conduzir o projeto. "Não se faz projeto quando só se tem certezas, ou quando se está imobilizado por dúvidas”. (MACHADO, 2000, p.7)

- Possui um agente, indivíduo ou grupo, que tem por interesse a realização do projeto. Não se pode projetar pelo outro, isto é, determinar as metas ou realizar as ações que dizem respeito a outro indivíduo/grupo.

O presente trabalho é fruto de um projeto $^{13}$ que, do ponto de vista da definição acima, possui como agente uma pesquisadora-docente. Como pesquisadora, estabeleci as metas visando resultados satisfatórios para cumprir os objetivos da pesquisa já detalhados. Como docente, desenhei metas com o fim de oportunizar aos alunos experiências significativas de aprendizagem. A compreensão dessa duplicidade de papéis do agente do projeto é imprescindível para a realização/ leitura do trabalho.

A definição de projeto citada nos conduziu ao entendimento da impossibilidade de se projetar pelo outro, reforçando a ideia de que

- as situações adidáticas teriam melhores resultados, quanto maior fosse a coincidência entre o projeto de ensino (dos professores envolvidos na pesquisa) e o projeto de aprendizado (de cada aluno que participa desta pesquisa).

a Sequência Didática deveria favorecer a devolução a cada aluno da responsabilidade de desenvolver o seu próprio projeto de aprendizagem não ausentando dos professores sua responsabilidade de direcionar o projeto coletivo de ensino, com o qual os projetos individuais dos alunos devem caminhar paralelamente num tempo longo, que ultrapassa os limites temporais da relação didática.

- ao aplicar o projeto em sala de aula, deveria se evitar dar respostas aos problemas, em vez disso esperar que o aluno as encontrasse por si. Ao antecipar as respostas o professor tem a falsa sensação de que pode desenvolver pelo outro (o aluno) as ações que julga necessárias para o aprendizado.

\footnotetext{
${ }^{13}$ O uso do termo "projeto" no decorrer deste trabalho não se vincula à metodologia de ensino por projetos, mas sim ao projeto (no sentido amplo) por mim desenvolvido, de pesquisa e ensino, que engloba desde o surgimento da pergunta norteadora do presente trabalho até as fases finais de análise.
} 


\section{Definindo tema e faixa-etária}

Considerando os objetivos do projeto, o tema Análise Combinatória revelou-se extremamente rico por exigir criatividade de resolução e uma diversidade de raciocínios.

Embora a Análise Combinatória disponha de técnicas gerais que permitem atacar certos tipos de problemas, é verdade que a solução de um problema combinatório exige quase sempre engenhosidade e a compreensão plena da situação descrita pelo problema. Esse é um dos encantos desta parte da Matemática, em que problemas fáceis de enunciar revelam-se por vezes difíceis, exigindo uma alta dose de criatividade para sua solução. [...] Se a aprendizagem destes conceitos se faz de maneira mecânica, limitando-se a empregá-los em situações padronizadas, sem procurar habituar o aluno com a análise cuidadosa de cada problema, cria-se a impressão de que a Análise Combinatória é somente um jogo de fórmulas complicadas. (MORGADO, 1991, p. 3)

Análise Combinatória é um tema que perpassa todos os níveis escolares. Desde o primeiro ciclo do Ensino Fundamental até o nível médio, os documentos oficiais recomendam que se explore o raciocínio combinatório. Para explorar o tema sem restrições, optamos por planejar e aplicar uma sequência no Ensino Médio.

\subsection{A Sequência Didática}

Tendo em vista o público alvo e o tema, já determinados, elaboramos uma Sequência Didática a fim de proporcionar situações potencialmente adidáticas.

Construímos uma Sequência Didática, com 8 desafios, nos quais procuramos abranger diferentes raciocínios combinatórios. Na sequência, aparecem problemas de Permutação simples, permutação com repetição, Arranjo Simples e Combinação simples, entre outros.

Ao terem contato com a Sequência Didática, os alunos não precisavam conhecer as fórmulas de Análise Combinatória e seria até desejável que não conhecessem para que por eles mesmos pudessem raciocinar sobre cada desafio e formular hipóteses para a resolução.

A sequência ocorre num contexto fictício, em que uma personagem, Marcela, deparase constantemente com a necessidade de realizar contagens indiretas. A narrativa tem a função de dar coesão à sequência e motivar a sua leitura. 


\section{A cidade de Contagem}

Marcela passou no vestibular. A alegria de sua família e amigos foi imensa... Até o momento em que descobriram que ela precisaria fazer as malas. Como a universidade ficava muito longe de casa, Marcela procurou na Internet um lugar para morar, que fosse tranquilo e próximo da universidade.

Durante sua pesquisa, ela descobriu uma cidade com essas características. Chamava-se CIDADE DA CONTAGEM.

Marcela sempre foi conhecida por sua indecisão. Nunca sabia que escolha fazer. Ir para o cursinho a pé ou de ônibus? De tênis ou de bota? À tarde ou de manhã? Era isso inclusive que preocupava as pessoas: como ela iria se virar? Morar sozinha implica em tomar muitas decisões importantes. E como ela faria isso longe de todos?

Mas essa foi a primeira vez que ela não pensou duas vezes, preparou a bagagem, comprou a passagem e cobriu-se de coragem para iniciar a viagem a uma nova fase de sua vida.

Seus amigos e familiares começaram a dar conselhos estranhos, mas ela ignorava, pensando: "Com certeza, eles combinaram tudo isso para me fazer desistir da mudança".

- Não vai pra essa cidade não, minha filha. Dizem que todos que vão pra lá ficam com uma mania esquisita.

- Cidade da contagem? Não acredito que você vai pra lá!!! Você está de brincadeira, né?

- Você nunca ouviu falar do contágio da Contagem? É o assunto do momento... Não sei em que mundo você vive!

Figura 1- Sequência Didática: primeira parte

Alguns autores como Cruz (2006) vêm explorando a importância das narrativas no ensino especificamente da Matemática, como "fontes inesgotáveis para a produção do significado". Tem-se percebido que a narrativa é um recurso didático dos mais profícuos para promover a significação dos conteúdos matemáticos.

Em minha prática de ensino, também tenho observado o quanto a narrativa atrai as pessoas, independentemente de idade, sexo, classe social, nível de formação. A conciliação desse recurso, quando possível, ao ensino de algum tópico de Matemática contribui para que os alunos se interessem pelo tema, compreendam sua importância e, desse modo, tenham maior facilidade de assimilação. 


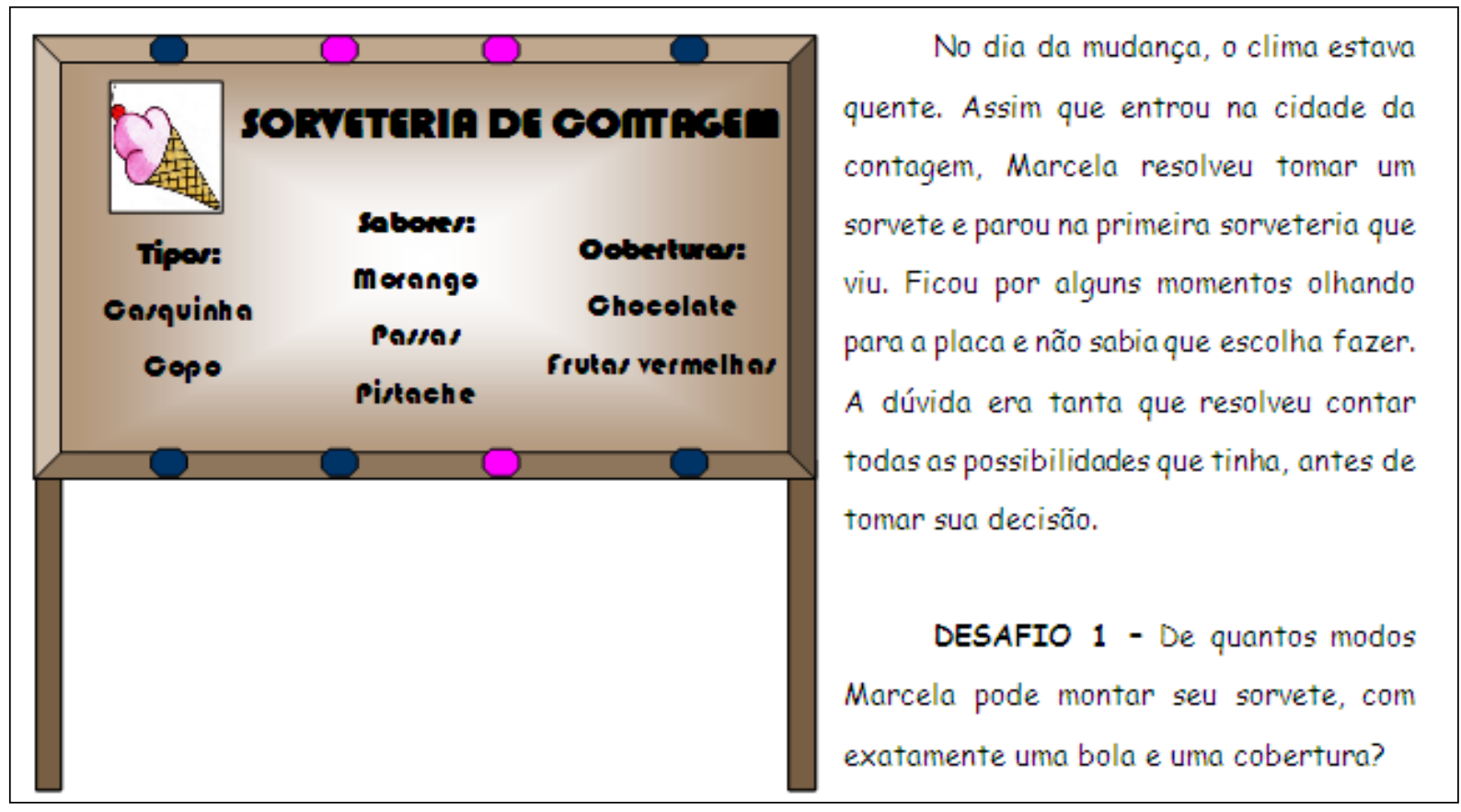

Figura 2- Sequência Didática: primeira parte

A solução desse primeiro desafio envolve o que é de fundamental para a Análise Combinatória, como o próprio nome diz: o Princípio Fundamental da Contagem (PFC), conhecido também como princípio multiplicativo, segundo o qual para tomar uma decisão que envolve $n$ escolhas, se para cada escolha temos $k_{1}, k_{2}, \ldots k_{n}$ opções, teremos o produto $k_{1} \times k_{2} \times(\ldots) \times k_{n}$ como o total de possibilidades para essa decisão. No caso desse desafio, para montar o sorvete, Marcela tem 3 escolhas a fazer, para as quais se oferecem 2, 3 e 2 opções. Portanto, o total de possibilidades de sorvete é $2 \times 3 \times 2=12$. Marcela pode montar seu sorvete de 12 modos.

Esperávamos com esse desafio que os alunos enumerassem cada uma das possibilidades, mas que percebessem o PFC como generalização de problemas desse tipo. Caso não percebessem, deveríamos despertar sua curiosidade com perguntas do tipo: E se fossem mais sabores? E se fossem mais coberturas? 
O sorvete chegou, e com ele a maquineta em que ela deveria digitar a senha do cartão de débito. Marcela havia esquecido a senha completamente. Lembrava apenas que a senha tinha 4 dígitos numéricos e que eram todos ímpares. Não lembrava, nem mesmo, se tinham algarismos repetidos.

Por sorte havia trazido consigo uma quantia em dinheiro. Marcela pagou o sorvete e foi sentar-se para tomá-lo, muitíssimo preocupada, não pela senha, pois bastava ligar para sua mãe e esta lhe diria a senha. Marcela estava preocupada com a solução de um novo desafio.

DESAFIO 2 - Supondo que o cartão não fosse bloqueado depois de várias tentativas e que o sorvete não fosse derreter enquanto ela tentava várias senhas, no máximo, quantas vezes ela precisaria digitar?

Figura 3- Sequência Didática: primeira parte

Essa situação é mais difícil de enumerar. Sendo assim, esperávamos que mesmo que os alunos tivessem enumerado as possibilidades no desafio anterior, neste segundo desafio sentiriam a necessidade de desenvolver uma estratégia indireta de contagem. Ainda assim, acreditávamos que os alunos iniciariam a resolução enumerando algumas dessas possibilidades: $1111 ; 1113 ; 1115 ; 1117 ; 1119 ; 1131$; etc.

Com isso perceberiam, aos poucos, que há 5 possibilidades para o último dígito, mantendo-se os 3 primeiros; há $5^{2}$ possibilidades para os dois últimos dígitos, mantendo-se os dois primeiros; há $5^{3}$ possibilidades para os três últimos dígitos, mantendo-se o primeiro; e assim, há $5^{4}=625$ possibilidades de senha.

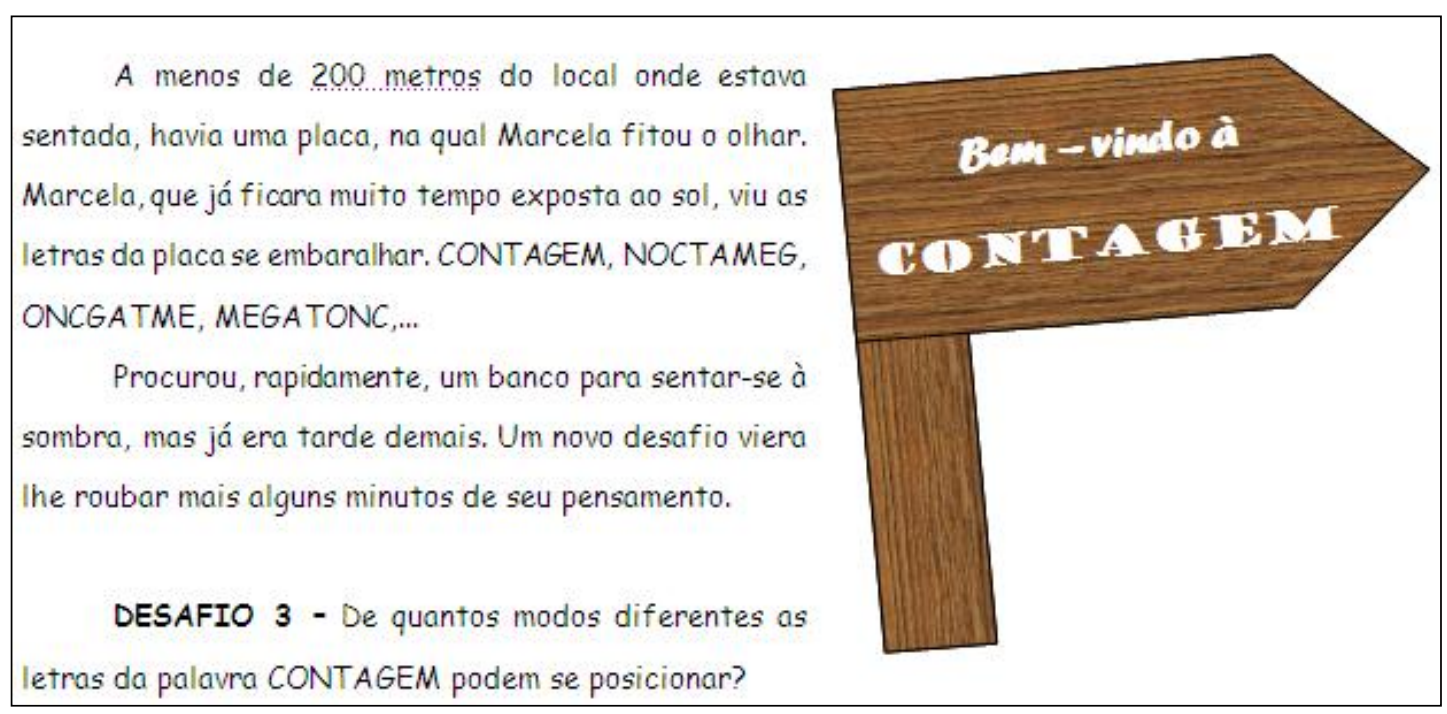

Figura 4- Sequência Didática: primeira parte 
Esse desafio também é baseado no PFC, como todos os desafios dessa sequência, mas nesse caso envolvendo uma PERMUTAÇÃO SIMPLES. Se levassem em consideração o que foi feito no desafio anterior, os alunos responderiam que são $8^{8}$ os modos de permutar as letras da palavra contagem.

Há, no entanto, uma diferença neste desafio. As letras na palavra não podem se repetir como os algarismos na senha. 1113 é uma senha permitida, enquanto CCCOOGGG não é um anagrama permitido. A nova dificuldade que esse desafio traz é pensar que as letras não podem se repetir, assim sendo, ao optar por uma letra para ser a primeira, restam 7 opções para segunda letra; feita a escolha, restam 6 opções para a terceira letra; e assim sucessivamente. Portanto o número de anagramas da palavra CONTAGEM é $8 !=8 \times 7 \times 6 \times 5 \times 4 \times 3 \times 2 \times 1=40.320$.

O interessante de tudo isso é que Marcela não escreveu todas as palavras para contá-las uma a uma. Ela elaborou uma estratégia para resolver esse desafio. E a cada novo desafio, ela elaborava uma nova técnica para contar.

Marcela terminou de tomar o sorvete e ligou para sua mãe. Esta, ansiosa por receber o telefonema, fez milhares de perguntas antes de deixar sua filha contar o episódio da senha. Então a mãe de Marcela disse-lhe o número da senha, sucedido por inúmeros conselhos, como era comum.

Depois que desligou o celular, Marcela pensou: "Puxa vida! Se eu tivesse lembrado, ao menos, que na senha não tem 1 nem 9, e que o único dígito que se repete duas vezes é o 3... Teria ficado bem mais fácil."

DESAFIO 4 - Com essas dicas, quantas senhas ainda são possíveis?

Figura 5- Sequência Didática: primeira parte

Nesse desafio, análogo ao anterior, em vez de permutar as 8 letras da palavra contagem, os alunos devem calcular a permutação dos algarismos 3, 3, 5 e 7, percebendo que há repetição do algarismo 3 . A solução desse desafio é, portanto, $(4 !) \div 2=4 \times 3=12$.

Há duas dificuldades aqui. Uma delas é perceber que se trata de uma permutação, pois com as dicas fornecidas, resta saber a ordem em que os algarismos 3, 3, 5 e 7 aparecem na senha. A outra dificuldade é perceber que, como o algarismo 3 se repete, ao calcular a 
permutação simples, obtemos duas vezes cada combinação, devendo, portanto dividir esse resultado por 2. Este é um problema de PERMUTAÇÃO COM REPETIÇÃO.

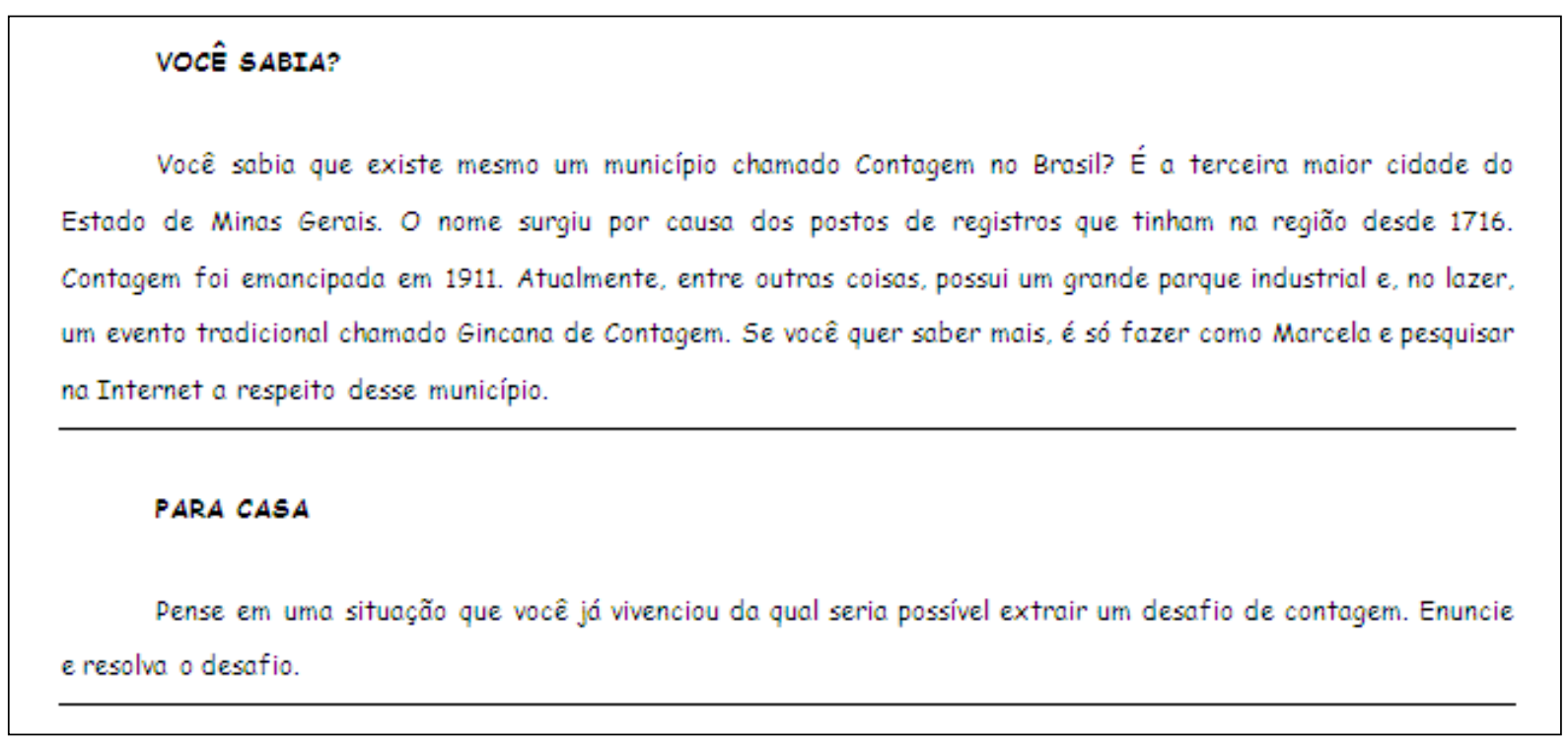

Figura 6- Sequência Didática: primeira parte

A cidade de Contagem na ficção tem esse nome para fazer referência à Análise Combinatória. No entanto, a título de curiosidade, revelamos aos alunos que de fato existe uma cidade com esse nome no Estado de Minas Gerais, inclusive abrindo um caminho possível para um trabalho interdisciplinar.

O desafio para casa tem, pelo menos, dois objetivos. Um deles é mostrar aos alunos que o conteúdo Análise Combinatória pode ser relacionado ou aplicado a vários acontecimentos do cotidiano. Outro objetivo é verificar se os alunos são capazes de aplicar o conhecimento construído em aula em outras situações, ou seja, verificar se de fato aprenderam.

Essa primeira parte da Sequência Didática envolve Princípio Fundamental da Contagem, Permutação Simples e Permutação com repetição. Espera-se com ela apenas introduzir essas ideias fundamentais da Análise Combinatória. Para que o aluno se desenvolva no conhecimento desses temas é preciso resolver mais exercícios de modo que o raciocínio desenvolvido seja aplicado a diversas situações.

Algumas sugestões de aplicação desses raciocínios em outras situações, porém no mesmo contexto da história, estão na sequência. Os mesmos podem ser feitos em casa ou 
mesmo na sala para complementação e fixação das ideias. As respostas já se encontram ao lado do enunciado para que o aluno possa comparar sua resposta com o gabarito. Deve-se ressaltar, no entanto, que uma resposta correta não implica numa resolução correta, podendo o aluno chegar por coincidência à resposta, o que precisa ser verificado posteriormente.

\section{MAIS DESAFIOS PARA VOCE...}

1. Enquanto esperava o sorvete, Marcela olhava à sua volta, pensando em como seria divertido conhecer novos ambientes e novas pessoos. Pegou a máquina fotográfica e começou a registrar aquele momento. Foi quando o placa da sorveteria the chamou a atenção mais uma vez. Agora, eram as 8 luzes em seu contorno, que acendiam e apagavam aleatoriamente, estando sempre pelo menos uma acesa. Começou a pensar: "Quais as lâmpadas que estarão acesas quando eu bater a foto?". E o desafio estava lançado... Responda: De quantos modos diferentes as luzes poderão sair na foto? (Resposta: $2^{5}-1$ )

2. De quantos modos podem ser embaralhadas as letras do seu nome? (Resposta pessoal)

3. De quantos modos as letras da palavra CONTAGEM poderiam ser embaralhadas

a) iniciando com $C$ e terminando com $M$ ? (R. 720)

b) mantendo as vogais todas juntas? (R. 4.320)

c) sem que as letros Te A fiquem juntos? (R. 39.240)

4. Qual seria a resposta do desafio 2.

a) se não tivessem digitos repetidos? (R. 120)

b) se não tivessem dígitos repetidos $e$ fossem 5 dígitos $\mathrm{em}$ vez de 4 ? (R. 120)

5. Se a senha de quatro dígitos de Marcela fosse composta apenas por algarismos pares, não podendo começar por 0 , quantas tentativas ela teria de fazer

a) não sabendo se tinham algarismos repetidos? ( $R$. 500)

Figura 7- Sequência Didática: primeira parte 
A cidade de Contagem (parte 2)

Marcela gostou muito de sua faculdade. Tudo era muito diferente da escola: mais liberdade $e$ mais responsabilidade. Ao término do primeiro dia de aula, a professora coordenadora entrou na sala, dizendo que, dentre os 40 alunos de sua turma, eles deveriam escolher 5 alunos distintos para compor uma comissõo de representantes da turma. Cada um dos 5 representantes teria uma função diferente: integração, comunicação, repasse de documentos. participoção em assembléias e promação de eventos. Marcela ficou pensando: De quantos modos diferentes pode ser escolhida essa comissõo?

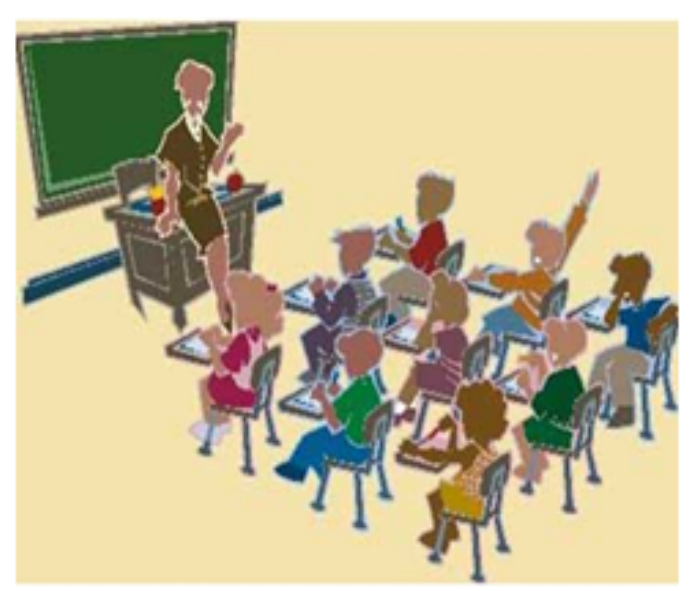

DESAFIO 5 - De quantos modos é possível formar uma comissão de 5 alunos, dentre os 40 , de modo que cada um tenho uma funçäo diferente?

Figura 8- Sequência Didática: segunda parte

Na primeira parte da Sequência Didática, muitos raciocínios não foram explorados, como os de ARRANJO SIMPLES e COMBINAÇÃO SIMPLES. Para dar conta dessas ideias também fundamentais da Análise Combinatória, foi criada essa segunda parte da Sequência.

O desafio 5 é um caso de Arranjo Simples. A diferença desse desafio para os desafios que envolviam permutação é que nele a quantidade de vagas e de candidatos não é a mesma. Há 5 vagas e 40 candidatos. Dessa forma, a solução do desafio é dada por $40 \times 39 \times 38 \times 37 \times 36=78.960 .960$ modos de formar uma comissão.

Os alunos discutiram e chegaram à conclusão de que não era necessária a divisão de funções. Os 5 integrantes da comissão deveriam trabalhar em conjunto, assumindo todos os papéis de representantes da turma. Marcela logo percebeu que, com essa mudança, o número de comissões possíveis também mudou.

DESAFIO 6 - De quantos modos é possível formar uma comissão de 5 alunos, dentre 0 s 40 , não havendo distribuição de tarefas?

Figura 9- Sequência Didática: segunda parte 
O desafio 6 é um caso de COMBINAÇÃO SIMPLES. A novidade dele, com relação ao desafio 5, é que agora tanto faz uma equipe formada pelos alunos A, B, C, D e E ou pelos alunos E, D, C, B e A. A ordem não importa, porque eles não irão desempenhar funções diferentes. Cada grupo de 5 alunos pode permutar de $5 !=120$ formas diferentes. Portanto, o resultado obtido no desafio 5, deve ser agora dividido por 120, resultando em 658.008 modos de se formar essa comissão.

Hora de ir para a casa. Marcela pegou o trem com destino à prefeitura Municipal de Contageme, a partir de lá, iria caminhando até a sua moradia. Tinham seis lugares para se sentar no vagão em que entrou, no entanto, ela sentou-se no primeiro banco próximo à porta, pois suas malas estavam pesadas. $\mathrm{Na}$ estação seguinte, ninguém se levantou e entraram no vagão mais 3 mulheres e 2 homens. Enquanto escolhiam os lugares para se sentar, Marcela propôs a si mesma um novo desafio.

DESAFIO 7 - Desprezando a individualidade dos passageiros recém-chegados e levando-se em consideração apenas o sexo, de quantos modos homens e mulheres podem posicionar-se?

Figura 10- Sequência Didática: segunda parte

Há 5 lugares, os quais deverão ser ocupados por 3 mulheres e 2 homens. Trata-se da permutação de 3 mulheres e 2 homens, o equivalente à permutação das letras MMMHH, ou seja, uma permutação com repetição. Sendo assim, divide-se 5! por 2! (permutação das letras $\mathrm{M}$ entre si) e por 3! (permutação das letras $\mathrm{H}$ entre si). Isso resulta em 10 modos de permutar homens e mulheres.

Além do desafio 7 ser mais difícil que os anteriores pela própria complexidade, que é crescente no decorrer da Sequência, entendemos que a compreensão desse enunciado também é mais difícil pela condição posta: "levando-se em consideração apenas o sexo". No entanto, optamos por deixar o desafio para ver como os estudantes lidam com ele.

O desafio 8 é totalmente análogo ao desafio 7 e tem, portanto, o mesmo resultado, 10. Essa analogia entre desafios é também muito importante em Análise Combinatória. 
Há, nesse desafio, uma dificuldade maior. Perceber que o problema dos caminhos pode ser transformado numa permutação com repetição não é natural, intuitivo. Independente do caminho escolhido, Marcela deverá caminhar 3 vezes em uma direção e 2 vezes na outra.

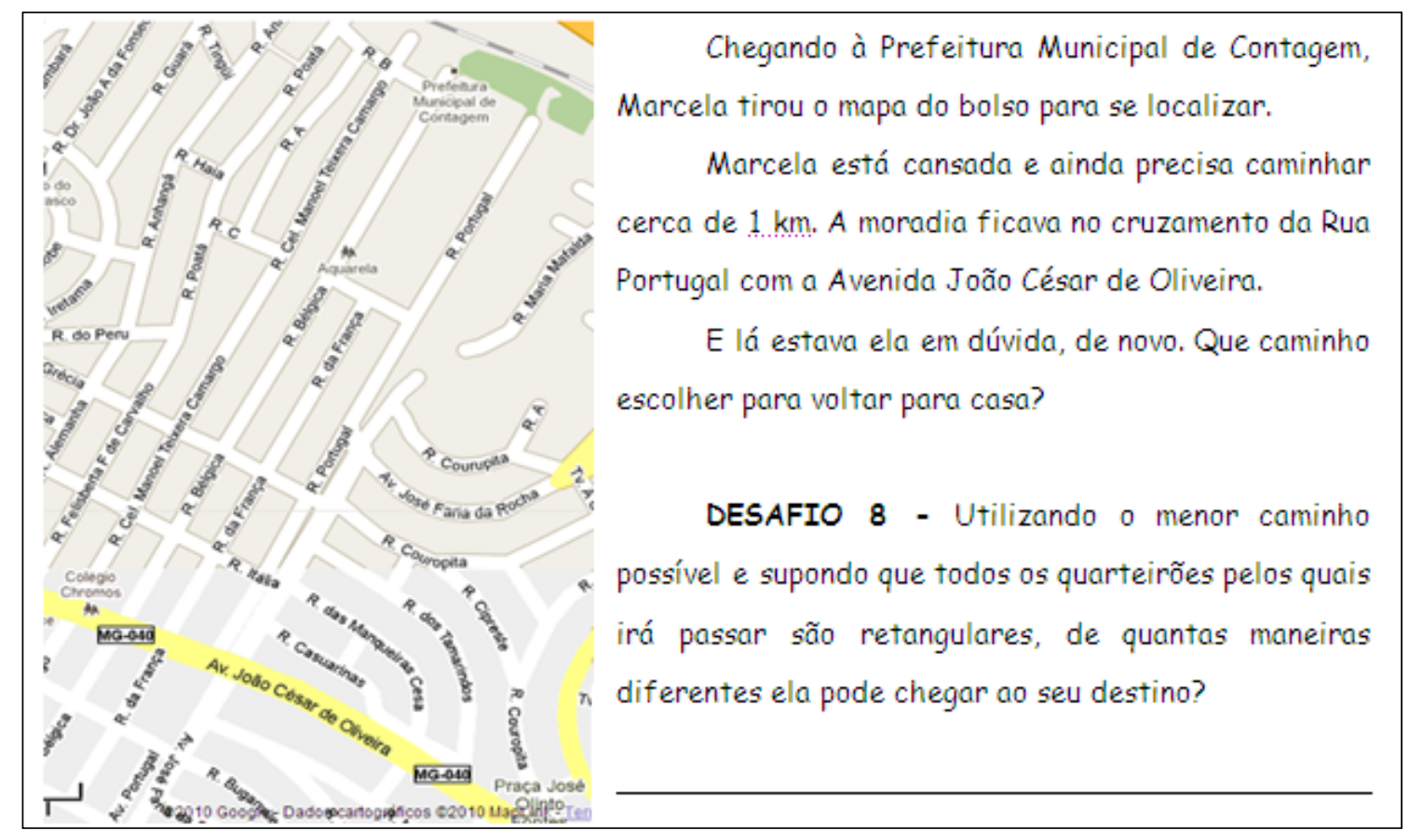

Figura 11- Sequência Didática: segunda parte 


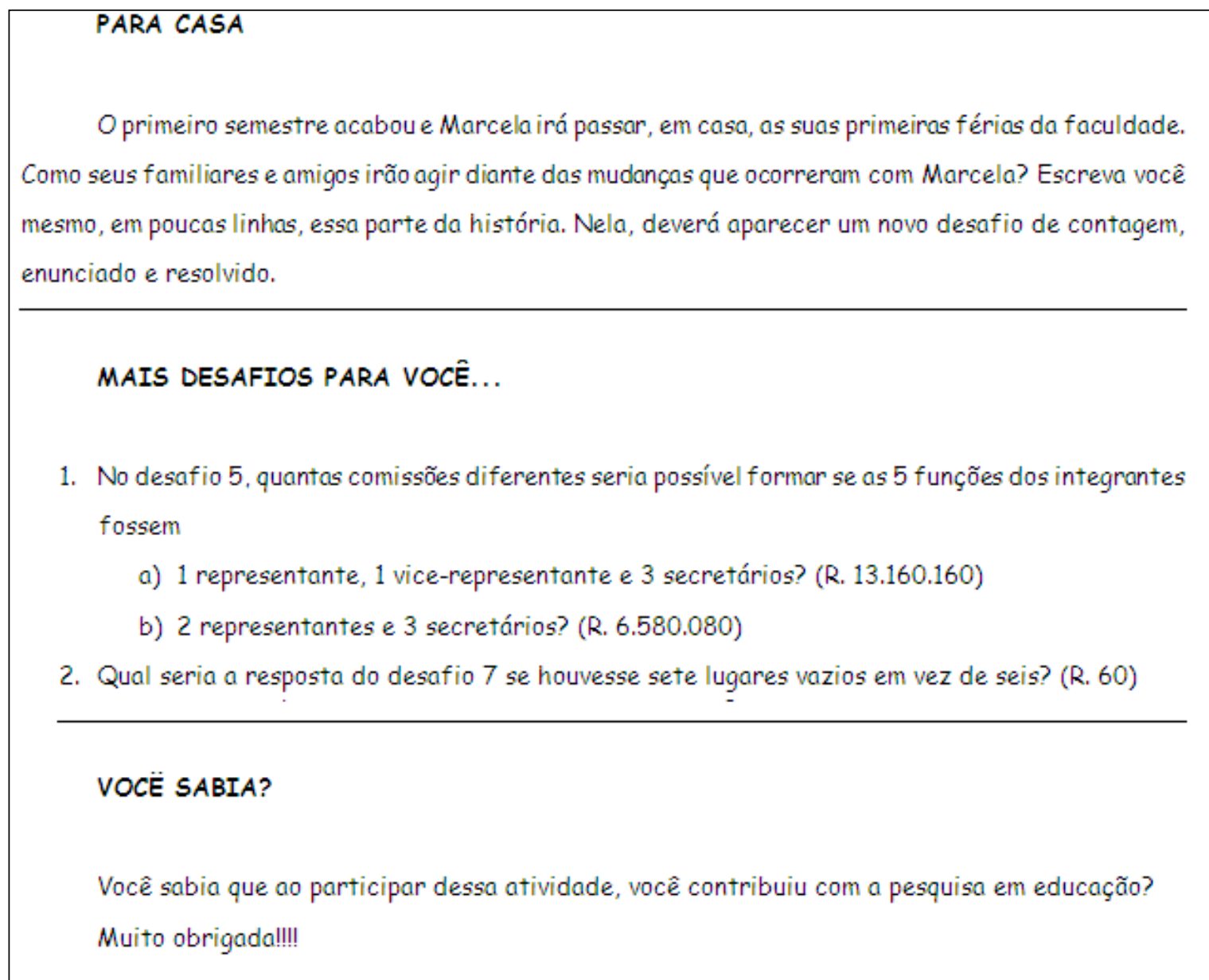

Figura 12-Sequência Didática: segunda parte

Assim como a primeira, a segunda parte da Sequência Didática é encerrada com um desafio para casa, exercícios para a fixação dos raciocínios abordados e um "Você sabia?", com objetivos similares aos da primeira parte.

\subsection{Desenvolvimento da pesquisa}

Aplicamos o projeto, inicialmente, na Escola de Aplicação da USP em 2010. O professor de Matemática das duas turmas de $3^{\circ}$ ano da escola, cedeu 3 aulas de cada uma das duas turmas para que o projeto fosse aplicado. Ele participou tanto na elaboração da Sequência Didática, como no desenvolvimento do projeto em sala, tendo consciência dos objetivos e propostas da pesquisa. Durante a aula, os alunos se dispuseram em grupos para a realização da atividade proposta. 
Os registros que temos dessas aulas são:

- Vídeo com câmera fixa: esse vídeo é apenas audível quando, ao término de cada desafio, vou à lousa para resolvê-lo. Enquanto os grupos estão discutindo, é possível apenas ver seus movimentos e reações.

- Gravação de áudio: posicionamos em apenas um dos grupos por sala. Devido à qualidade do som, selecionamos apenas uma gravação, na qual se encontram as resoluções dos DESAFIOS 1 a 4 por parte de um grupo específico. Com muita dificuldade, tentamos, depois de 4 anos, diferenciar as vozes dos alunos que falam. Desse modo, a divisão feita no texto (aluno A, aluno B, etc.) é apenas para facilitar a leitura e não para analisar os diferentes alunos.

- $\quad$ Registros das atividades realizadas em papel.

Minha segunda experiência com essa Sequência Didática foi em 2011, numa instituição privada em que trabalhava, o SESI. Dessa vez, o mesmo conteúdo foi aplicado com alunos do $2^{\circ}$ ano do Ensino Médio durante 20 aulas, quantidade essa que fornece mais elementos para uma análise. Apesar de se tratar de uma instituição privada, há coisas em comum entre a rede SESI e uma rede pública, como os alunos não pagarem altas mensalidades (no SESI, os não isentos pagam um valor simbólico). Além disso, o relato dessa experiência no presente trabalho pode fornecer uma base comparativa entre o sistema público e privado, apesar de não ser esse o foco principal do trabalho.

Os registros dessas aulas são da seguinte natureza:

- Vídeo com câmera móvel: ao passear pela sala, tirando as dúvidas dos grupos, a câmera me acompanhava, de modo que as observações feitas no vídeo refletem as observações e posturas que assumi, como docente, diante das dúvidas dos alunos. Esse modo de registro, apesar de não facilitar a observação das situações adidáticas, pela constante presença do professor no vídeo, revela momentos importantes da relação aluno - professor saber.

- $\quad$ Registros das atividades realizadas em papel.

A última experiência se dá novamente na Escola de Aplicação, agora no ano de 2014, envolvendo um grupo muito especial de licenciandos em Matemática, os quais participam do PIBID - Programa Institucional de Bolsa de Iniciação à Docência. 
Dessa vez, meu papel é de apenas observar a aplicação do projeto por parte desses alunos-professores para com os alunos da Escola de Aplicação do $2^{\circ}$ ano do Ensino Médio, orientando-os com base nas experiências já obtidas. A grande diferença aqui, é que a situação não ocorre em uma sala de aula convencional, mas durante o contra turno com quatro alunos que se voluntariaram a serem observados. A situação analisada tem duração de 2 horas.

Os registros da pesquisa que serão utilizados na análise desse terceiro momento:

- $\quad$ Áudio de entrevista realizada com os bolsistas antes da aplicação da sequência;

- Questionário respondido pelos bolsistas após a aplicação da sequência;

- Áudio de entrevista realizada com o professor das turmas da Escola de Aplicação;

- $\quad$ Áudio da aplicação da Sequência Didática com os alunos;

- $\quad$ Registros das atividades realizadas em papel. 


\section{Capítulo 3: Uma sequência, três momentos}

Nesse capítulo, pretendo fazer uso da memória e dos registros para percorrer, novamente, com o leitor, a trajetória de aplicação do projeto de Análise Combinatória. Passaremos por três momentos, os quais nos forneceram elementos para a verificação da hipótese da situação adidática como ferramenta, entre outras análises pertinentes ao tema da pesquisa. Cada um desses três momentos se passa em cenários próprios de tempo-espaço, os quais buscarei caracterizar ao máximo. Cada um desses três momentos, dispostos em ordem cronológica, revela também diferentes fases de minha vivência como professora.

\subsection{Primeiro momento - Escola de Aplicação, 2010}

\subsubsection{Cenário}

Esse primeiro momento, ou seja, a primeira aplicação da Sequência Didática ocorreu no início da minha carreira como professora. Após conhecer a teoria das situações adidáticas, logo me interessei pela pergunta do presente trabalho "É possível elaborar situações potencialmente adidáticas?”

Para tentar responder a essa pergunta, contei primeiramente com a ajuda do professor Ernani Nagy de Moraes, professor das duas turmas de $3^{\circ}$ ano da Escola de Aplicação (EA), que reservou o espaço de 3 aulas em cada turma para que o projeto fosse aplicado. Ele participou da elaboração da Sequência Didática ${ }^{14}$ e também na sua aplicação.

Na Escola de Aplicação (EA) da USP, os alunos do $3^{\circ}$ ano do Ensino Médio ainda não tinham tido contato com o tema Análise Combinatória, por algum motivo particular da escola. Já era o final do ano de 2010 e os alunos, como conta o professor das turmas, cobravam alguma referência ao tema, por se aproximar o vestibular.

\footnotetext{
${ }^{14}$ A Sequência Didática encontra-se na seção 2.2
} 


\section{$\underline{\text { A Escola de Aplicação }}$}

A EA, vinculada à Faculdade de Educação da USP desde 1973 é uma escola pública que se diferencia das demais escolas da rede estadual, não apenas por ser sediada na Cidade Universitária, mas também por ter um regimento próprio que lhe permite desenvolver vários projetos e se beneficiar da estrutura da Universidade.

Sua contribuição para a educação pública é notória, primeiramente por ser o palco de várias pesquisas educacionais vinculadas à Universidade, e também por receber estagiários, futuros professores, aos quais dedica atenção especial.

A escola declara como objetivos em seu regimento:

I. Sediar e executar pesquisas de interesse próprio ou da Faculdade de Educação, de seus cursos e docentes, que visem ao aperfeiçoamento do processo educativo e de formação docente.

II. Oferecer oportunidades de estágio a alunos da Faculdade de Educação e a outras unidades da Universidade de São Paulo.

III. Oferecer subsídios à Faculdade de Educação da USP ou outras agências Públicas de formação do educador.

IV. Divulgar experiências e contribuições resultantes de suas ações, prioritariamente para a rede pública de ensino.

$\mathrm{V}$. Assegurar aos educandos a formação comum indispensável para o exercício da cidadania e o usufruto do trabalho. ${ }^{15}$

\section{Desenvolvimento das aulas}

Nas duas primeiras aulas, a sala se dividiu em grupos de 4 ou 5 alunos. Cada grupo deveria realizar as questões da sequência num tempo determinado em uma folha sulfite, na qual deveriam especificar o raciocínio utilizado. Enquanto isso, eu e o professor da sala, caminhávamos entre os grupos procurando dar dicas e tirar dúvidas. Ao término do tempo, formávamos um grande grupo para discutir sobre a questão, que eu resolvia na lousa.

Foi registrado o áudio de um dos grupos de cada sala. Uma gravação ficou mais clara que a outra, portanto ela foi escolhida para análise.

As seis primeiras questões da sequência foram resolvidas durante duas aulas. E na terceira aula o professor da sala fez a parte da institucionalização do conteúdo, mostrando aos alunos nomenclaturas e fórmulas.

\footnotetext{
${ }^{15}$ Disponível em http://www2.ea.fe.usp.br/wp-content/uploads/2014/05/Regimento-escolar-EA.pdf , visualizado em junho/2014
} 
Pudemos perceber no desenrolar da aula, como um todo, um ambiente propício para uma situação adidática. Alunos em grupo, motivados pela Sequência Didática e pelos desafios matemáticos nele contidos, discutindo as formas de solucionar cada um deles.

No entanto, percebemos alguns fatores que, de algum modo, não permitiram uma maior aproximação entre essas situações e o que consideramos adidático. Por exemplo, no terceiro ano do Ensino Médio, grande parte dos alunos realiza curso pré-vestibular. Durante o desenvolvimento do projeto, os alunos que faziam cursos preparatórios tentavam mostrar aos outros as fórmulas que haviam aprendido para resolver problemas de Análise Combinatória, na maioria dos casos utilizando as fórmulas erroneamente. Ao contrário do que se sucedeu, esperávamos que os alunos partissem de um raciocínio lógico para resolver os problemas e não de fórmulas que decoraram sem compreender o sentido.

Outro ponto que, de certo modo, interferiu em certo distanciamento de uma situação adidática foi o desinteresse de parte de alguns alunos, pois, por mais que tenhamos nos esforçado para integrar a Sequência Didática à rotina de aula, as atividades e aprendizados não estavam vinculados com os demais conteúdos que estavam vendo em Matemática, e não estavam "valendo nota", o que fez com que alguns alunos (não todos) se mostrassem desinteressados e não se preocupassem em realizar atividades para casa.

O tempo estipulado para aprender também pode ser um inimigo da situação adidática. Nessa situação específica os alunos tinham uma aula para resolver 4 desafios. Mas se pensarmos em qualquer situação escolar, o tempo para aprender sempre está bem delimitado. Retomando o que vimos no primeiro capítulo a respeito da Microgênese do Desenvolvimento, da Zona de Desenvolvimento Proximal e do Tempo Longo da Aprendizagem, perceberemos que cada aluno está numa fase de seu desenvolvimento, que cada um tem o seu próprio ritmo de aprender. Mas o tempo escolar não tolera as diferenças.

Algumas frases captadas no áudio dessa primeira aplicação que, no momento, nos pareceram naturais, mas que reforçam certa ansiedade que o tempo escolar nos impõe: "Pessoal, 10 minutinhos para fazer o segundo desafio, pode ser? Ou oito, sei lá...", "Gente, como tem 2, 3 minutos para o sinal, presta atenção só pra gente fechar o tema".

De todo modo, o que mais interferiu para que essas situações não pudessem se caracterizar totalmente como adidáticas foi a minha postura de docente. Ao aplicar o projeto, mesmo tendo em mente todos os objetivos aqui mencionados, eu sentia a necessidade de dar respostas e de "fazê-los" chegar à resposta certa, o mais rápido possível. A observação do 
vídeo e do áudio me fez pensar muito a respeito disso. A partir daí minha postura como professora começou a mudar.

\subsubsection{Análise dos dados}

W (explicando a resolução do desafio 1)- Você sempre pode pensar assim: Eu tenho duas possibilidades de tipos de sorvete, tenho três possibilidades de sabores, tenho duas possibilidades de cobertura. De cada um dos dois tipos, saem 3. De cada um desses seis tipos, saem dois. Se tivesse ainda mais duas opções de coisas para colocar em cima da cobertura, multiplicaria novamente por 2, né?. (...) Então essa ideia da multiplicação é fundamental para resumir o raciocínio na hora de calcular essa contagem. Todo mundo entendeu? Por que essa ideia vocês vão usar nos outros desafios também, então é importante que todo mundo tenha entendido. Por que a multiplicação? Todo mundo entendeu?

Apesar de estar preocupada com que os alunos entendam o porquê da multiplicação, algumas expressões tendem a fazê-los reproduzir apenas uma técnica: "você sempre pode pensar assim", “essa ideia vocês vão usar nos outros desafios também”. Minha própria fala induz os alunos a multiplicarem sem pensar no significado que essa multiplicação possui. Talvez sejam essas expressões de ordem que levem os alunos a não perceberem a necessidade de raciocinar.

É interessante também observar alguns costumes dos alunos. Por exemplo, eles consideram dispensável ler a história e vão direto ao desafio. Acreditamos que esta seja uma cláusula implícita do Contrato Didático: em geral, o início do problema costuma ser apenas um pretexto para o que se quer perguntar e não um contexto, de fato, essencial para se obter a resposta. Portanto, adquirem o costume de ler apenas a frase final dos problemas. Ao perceber que não é possível responder ao desafio sem ter lido a história, os alunos passam a ler a Sequência Didática por completo.

Aluna A - Desafio 2. Supondo que o cartão não fosse bloqueado...

Aluna B- Gente vai ter que ler.

Aluna A- iiii... não, não. Supondo que o cartão não fosse bloqueado depois de várias tentativas e que o sorvete não fosse derreter enquanto ela tentava várias senhas, no máximo, quantas vezes ela precisaria digitar? Ah, eu vou ter que ler gente. Vai, eu vou ler o negócio.

Aluna B - Então leia.

Aluna A - O sorvete chegou, e com ele a maquineta em que ela deveria digitar a senha do cartão de débito. Marcela havia esquecido a senha 
completamente. Lembrava apenas que a senha tinha 4 dígitos numéricos e que eram todos ímpares. Não lembrava, nem mesmo, se tinham algarismos repetidos (...)

A compreensão da narrativa parece então ser alcançada. No entanto, para compreender a proposta do desafio é preciso um debate em grupo.

Aluna A - "ó", teoricamente se a gente digitar 3 vezes errado a senha corta.

Aluno C - (risos) Isso que eu ia falar, ia bloquear.

Aluna A - Ia bloquear, ia bloquear.

[aluna D conta um caso em que o cartão foi bloqueado]

Aluna B- Ela ta perguntando quantas senhas no máximo. Três, porque depois de três bloqueia o cartão.

Aluno C- (risos)

Aluno A - Não, mas supondo que não bloqueie.

É preciso que um dos alunos ressalte a suposição do enunciado: "supondo que não bloqueie". E aí sim eles começam a pensar no problema matemático. Essa fase de compreensão do problema faz parte do que chamamos de devolução e é anterior às quatro fases postuladas por Brousseau para a resolução de um problema (ação, formulação, validação e institucionalização). Sem compreender o problema ou sem tomar o desafio como seu, o aluno não pode vivenciar a situação adidática.

É interessante notar também que a aluna D interrompe a discussão sobre o desafio para contar uma situação, vivenciada por ela, em que um cartão foi bloqueado. Essa atitude demonstra que os alunos assumiram, de fato, uma proximidade entre a narrativa e a sua realidade.

Ao pensar no problema matemático, os alunos pulam a etapa de ação, na qual, esperávamos que eles listassem algumas senhas possíveis. Acreditamos que isso ocorreu por causa das palavras de ordem "vocês sempre terão que multiplicar". Os alunos começam, então, pela formulação, mas apenas procurando que números multiplicar.

Aluna D - Gente, 4 dígitos? 4 vezes 4.

Aluna B - Por quê?

Aluna D - Porque pra cada um ela vai mudando. Tipo, se essa deu certo, ela tenta uma vez, ela tenta duas, tenta três, tenta a quarta.

Aluna A - "ó", então começa: números ímpares - 1, 3, 5, 7 e 9. Cinco números.

Aluna D - Então, ela vai tentar não vai? Se ela conseguir...

Aluna A - Cinco números ímpares e ela não sabe se são repetidos. Então, gente, 5 vezes 4,20 possibilidades ela teria. 
O único número que se encontra explícito no problema é o 4. Portanto, tendo que multiplicar alguma coisa, a primeira ideia é multiplicar o 4 pelo próprio 4. Alguém, então percebe, que o outro número que também aparece no problema é o 5 , pois são 5 os algarismos ímpares. Daí surge a segunda ideia: 4 vezes 5. É interessante notar que, apesar de apenas estarem procurando números para multiplicar, os alunos sentem inicialmente a necessidade de dar explicações mais complexas para o que estão fazendo. No entanto não sabem responder por que estão multiplicando a quantidade de dígitos da senha pela quantidade de dígitos possíveis.

W - 20 possiblidades?!

Aluna A - Porque são 5 números ímpares e 4 dígitos. Assim.

$\mathrm{W}-\mathrm{E}$ por que você multiplicou a quantidade de números pelos dígitos?

Aluna A - Porque sim, ué!

Nesse instante, percebi a necessidade de voltar à etapa de ação e solicitei aos alunos que listassem as senhas que começassem com 1-1.

W - "ó", faz o seguinte para mim. Marca aqui todas as possibilidades que começam com 1-1.

Aluna B - Nossa...

W - Se são 20, o que você vão marcar vai ser bem menos.

Alunos C e D - (risos)

$[\ldots]$

W - Aqui, só começando com 1-1 já tem 25 .

Aluna A - Mas é o que ela dá, se for seguir o método dela...

Nesta fala, a aluna A revela que está apenas tentando seguir o que foi proposto inicialmente por mim: multiplicar os números que aparecem no problema. A essa altura, alguém sugere pensar com mais calma:

Aluna B- "ó", gente, "ó"

Aluno C- Vamos pensar direito.

Aluna B - Vamos pensar!

Aluna B - (lê de novo o desafio)

Aluno $\mathrm{C}-\mathrm{Tem} 4$ dígitos.

Aluna D - Gente, então as possibilidades são imensas.

Aluno C - São imensas.

Aluna B - São infinitas.

Após a dica, os alunos percebem que 20 possibilidades de senha é muito pouco.

Aluna A - "ó", tinham 4 dígitos numéricos que eram todos ímpares, não lembra nem mesmo se tinham algarismos repetidos. Esse que é o problema. Porque aqui "ta" certo, só que se tiver repetido pode ser vezes 5.5 vezes 5 
vezes 2 , não vezes 4 . [...] 100 possibilidades, sabe por que, "ó", ela não lembra se tem algarismos repetidos. 5 vezes 5 vezes 4 porque se forem repetidos vão ser 5 números.

$[\ldots]$

Aluno $\mathrm{C}$ - Tem que ir fazendo menos 1. [...] 5 vezes 4 vezes $3 .$.

O aluno $\mathrm{C}$, provavelmente, já havia realizado algum problema de arranjo simples anteriormente e por isso lembrou-se de fazer $5 \times 4 \times 3 \times 2$. Ao perceber isso, ressalto a característica principal do arranjo simples: não há repetição dos elementos: não é o caso desse problema.

W - Se não tivesse número repetido estaria certo. Mas ela não lembra se tem número repetido ou não, pode ser por exemplo 7-7-7-7. Então se tem 5 possibilidades para o primeiro, tem 5 possibilidades para o segundo também, porque pode repetir.

Aluno C- Então todos vai ser 5?

O aluno entende, então, rapidamente, induzido pelas dicas que foram dadas, que nesse caso há 5 possibilidades para todos os 4 dígitos da senha.

$\mathrm{W}$ - Todos os dígitos tem 5 possibilidades para preencher.

Aluna $A-5$ vezes 5 vezes 5 vezes 5 . Se cada um tem 5 possibilidades, 5 à quinta, quem está com a calculadora?

Aluna $\mathrm{A}$ - Não gente, é 4 à quinta, porque são só 4 dígitos, a senha e não 5 dígitos.

Aluna B - São 4 dígitos e 5 possibilidades para cada um.

Aluna $\mathrm{A}$ - Então é 5 à quarta.

Aluna B -625 .

Aluna $\mathrm{C}-625$.

Vimos aqui concretizada uma situação adidática em que houve a devolução e uma formulação correta para a resolução do exercício: "São 4 dígitos e 5 possibilidades para cada um.- Então é 5 à quarta."

No entanto, algumas etapas da situação adidática foram prejudicadas por uma causa implícita de um Contrato Didático já conhecido por eles e reforçado por mim no início da aula: "os alunos devem seguir uma técnica, neste caso multiplicar os números que aparecem no problema". Na tentativa de acelerar o processo de aprendizagem, antecipo o raciocínio que deveria ser do aluno ${ }^{16}$.

Dado o tempo para resolverem o problema, vou à lousa e cometo o mesmo erro -

\footnotetext{
${ }^{16}$ BROUSSEAU (1986) caracterizaria esse efeito didático como Efeito Topázio.
} 
transmitir uma fórmula única de resolução: "Tudo bem que é a mesma coisa que a gente fez no anterior?" E ao desenhar uma árvore de possibilidades, resolvendo com ela o desafio 2, acrescento: "Então, tudo bem, gente, que temos que fazer 5 vezes 5 vezes 5 vezes 5 para sabermos o tanto de ramos que a gente tem no final?"

\section{Aluna B - Desafio 3: De quantos modos diferentes as letras da palavra CONTAGEM podem se posicionar?}

Os alunos lêem e relêem o desafio 3. Agora parecem mais familiarizados com a história e com a personagem. Depois da leitura, um dos alunos comenta: "Só essa Marcela (né?) que pensa nisso".

Aluna A - Olha, uma, duas, três [...] oito letras. Gente, "ó", vai ser a mesma coisa, são 8 letras. $\mathrm{O}$ alfabeto tem quantas letras?

Aluna D - Não.

Aluna A - São 8 letras.

Aluna D - Não, mas tem que seguir essa palavra CONTAGEM.

Aluna A - É. 8 letras e cada negocinho pode ter 8 possibilidades, 8 letras. 8 vezes... 8 elevado a 8.8 elevado a 8 . Não é? 8 elevado a 8 .

Aluno C-É.

Aluna B - Ta tudo errado, eu acho. Olha o número bonito que deu. 8 a 8.

Os alunos não percebem a diferença entre este desafio e o anterior. Agora, as letras "não podem se repetir". Mesmo o aluno que sugeriu, no desafio anterior, a resolução como Arranjo Simples, agora não sugeriu nada. A aluna B tem uma intuição de que algo está errado, mas por causa do número alto, então me chamam.

Alunos A e C $-\mathrm{W}$ !

Alunos A e C - Dá 8 elevado a oitava?

$\mathrm{W}$ - Por que 8 elevado a oitava?

Aluna A - Porque são oito letras.

$\mathrm{W}-$ Seria que nem esse aqui?

Alunos B e C - É.

W- Aqui eu poderia repetir 1-1-1-1. Aí eu não posso repetir letra: M-M-M... Aluna B - Então são 7. 8 elevado a 7. Se não pode repetir... Se a primeira for C, a próxima só pode ser outra. As outras sete letras que não foram coladas.

$\mathrm{W}-\mathrm{A}$ primeira tem 8 possibilidades.

Aluna B - A segunda tem 7. Já são 8 vezes 7 .

Aluno C - Não, mas tem que ir até o final. Vai ser 8, 7,

Alunos A e C - 6, 5, 4, 3, 2, 1 .

Aluno C- Você vai tirando até o final. A última tem uma possibilidade. Aí você multiplica 8 vezes 7 vezes 6 vezes...

Aluna D - Coloca isso "B", coloca... coloca.

Aluna B -40.320 possibilidades. 
Novamente, a fase de ação da situação adidática não foi percebida - os alunos não tentaram escrever alguns anagramas. Eu dei as dicas, considerando que todos já entendiam a Análise Combinatória. Mesmo assim, eles foram chegando às respostas e pareciam se sentirem satisfeitos por isso. Então passam para o último desafio do dia.

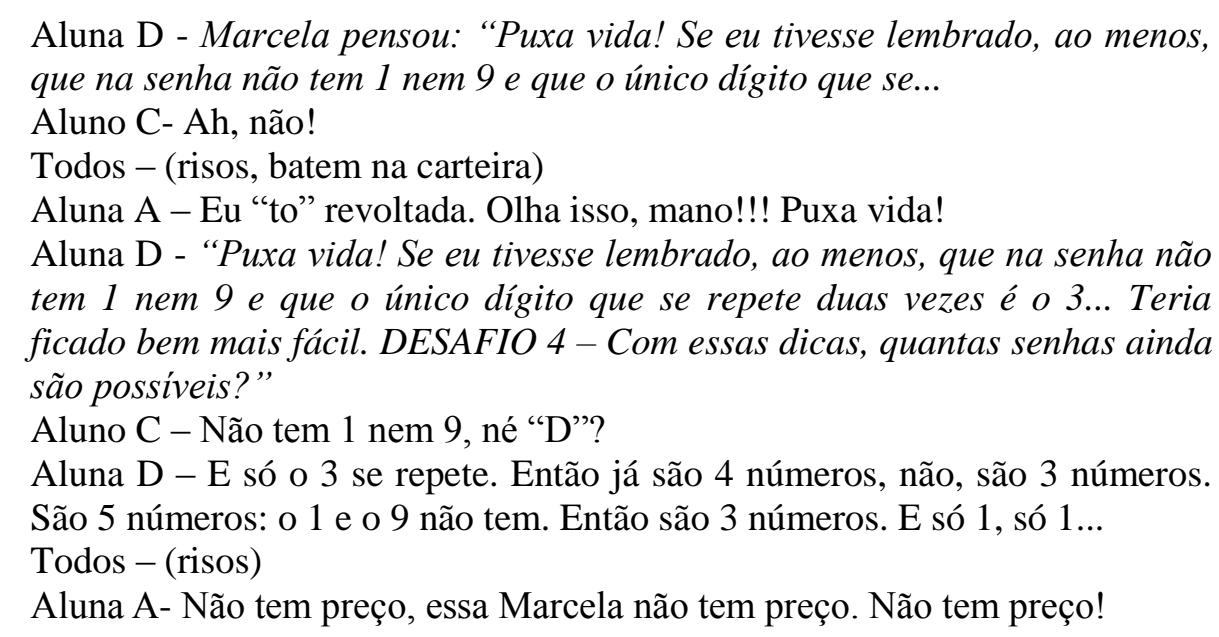

Os alunos de fato se envolvem com a sequência e com a personagem. Eles querem resolver o desafio. Vão discutindo e chegam a várias respostas possíveis, mas sempre tentando descobrir o que multiplicar, pulando a etapa de ação: $3^{4} ; 3$ !; $3^{2} ; 3^{3} \times 2 \times 2$. Então, eu me aproximo novamente desse grupo e explico que esse é um caso de permutação, pois a senha tem 4 dígito sendo eles 3-3-5-7, só não sabemos a ordem.

W - Se eu tivesse a palavra CASA e se eu precisasse trocar as letras de CASA, seria o mesmo problema, não seria? Porque eu tenho 2 letrinhas que se repetem. Esse problema e esse seriam o mesmo. Achar as trocas de letra da palavra CASA e as trocas desse número.

Aluna B - As possibilidades é 3

Aluna D - Não, as possibilidades são 4, "B".

Aluna A - Gente, eu acho mais fácil pensar do jeito que ela tava falando. Então vai ser tipo, no caso da CASA, seria tipo 4, 3,[...]

Aluno $\mathrm{C}-\mathrm{E}$ se fosse CONTOGEM...

Todos - (risos)

Aluna B - "Ó", vai... 4, 4.

Aluna A - Mas o 3 está repetido. Gente o que a gente faz?

Aluna $\mathrm{C}$ - Acho que é melhor esperar ela...

Um pouco os alunos se arriscam, depois voltam a se sentir inseguros, pois não sabem que multiplicação fazer. Em nenhum momento pensam em listar as possibilidades, perfeitamente possível, já que eram 12. 


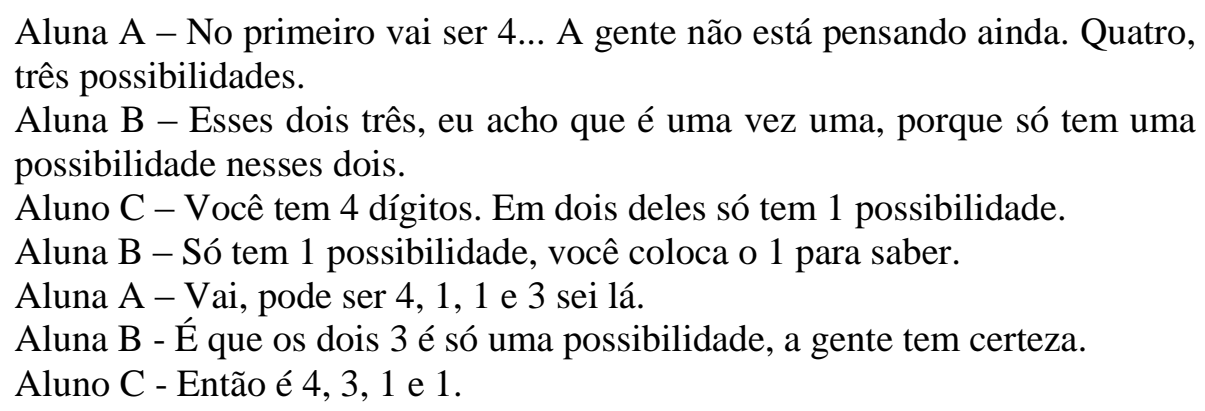

Como a aula está acabando, vou à lousa rapidamente e tento explicar como se faz o desafio em poucas palavras.

W - Só pra fechar o desafio 4 , gente. O 4 a gente faz do mesmo jeito do 3.
Então como é que ficaria? Eu tenho que trocar 4 coisas de lugar. Então
ficaria 4 fatorial, certo? 4 vezes 3 vezes 2 vezes 1 . A diferença é que eu
estou contando cada caso 2 vezes. Se eu estou contando o caso $3-3-5-7$ e eu
troco os dois dígitos, fica... 3-3-5-7, eu contei duas vezes a mesma coisa. Se
eu tiver $3-5-7-3$ e eu troco esses dois números de lugar, não vai ficar igual?
Então cada caso eu estou contando duas vezes. [...] Então se eu estou
contando cada caso duas vezes, eu... divido por 2 .

Hoje penso que seria melhor esperar até que o grupo chegasse por eles mesmos na resposta, mesmo que isso fosse feito em outra aula. Mas esse é apenas o primeiro momento. Relataremos outros dois, na busca de nos aproximarmos cada vez mais de nosso objetivo. Algumas mudanças foram pensadas para as próximas aplicações do projeto:

- $\quad$ Em primeiro lugar, a sequência deveria ser aplicada com alunos do $2^{\circ}$ ano para que as técnicas dos cursos pré-vestibulares não interferissem nos resultados.

- $\quad$ O projeto deveria minimamente fazer algum sentido para o aluno: deveria compor o quadro de conteúdos previstos para a disciplina de Matemática naquele ano e não mais ser um projeto solto, desvinculado do projeto maior que é a sequência de aulas que compõem o ano letivo.

- $\quad$ Além disso, seria preciso que eu, ou o professor que aplicasse o projeto, tivesse uma postura diferente, valorizando mais o raciocínio dos alunos, dando maior tempo para que cheguem às respostas. É preciso perguntar mais do que responder. Seria interessante, por exemplo, pedir para que os alunos fizessem a resolução na lousa, em vez de eu mesma fazê-la, impondo a minha estratégia de resolução. 


\subsection{Segundo momento - SESI, 2011}

\subsubsection{Cenário}

Neste segundo momento eu havia sido contratada pelo SESI, Serviço Social da Indústria e lecionava na Unidade Escolar da Vila Leopoldina, São Paulo, para alunos da $7^{\text {a }}$ série do Ensino Fundamental.

Entre fevereiro e março de 2011, fiquei por seis semanas também com as três turmas de segundo ano do Ensino Médio na Unidade Escolar do SESI - Vila Leopoldina em São Paulo. O professor da turma, antes mesmo de se apresentar, teve de tirar licença médica. Assumi as aulas durante esse curto período de tempo e vi nele a oportunidade de desenvolver o projeto.

Cada turma tem 4 aulas de Matemática por semana. Mas, devido aos feriados, ministrei cerca de 20 aulas em cada turma. A mesma metodologia foi aplicada no $2^{\circ} \mathrm{A}$, no $2^{\circ}$ B e no $2^{\circ} \mathrm{C}$, com variações mínimas.

\section{$\underline{\text { O SESI }}$}

O SESI, Serviço Social da Indústria surgiu em 1946 com o objetivo de proporcionar aos funcionários da indústria melhor qualidade de vida. O SESI é uma instituição de direito privado, mantida e administrada pela indústria, que presta serviços na área de esporte, saúde, educação, lazer e nutrição.

Atualmente, as escolas do SESI estão espalhadas pelas 26 unidades federativas do Brasil, sendo 211 unidades apenas no Estado de São Paulo.

A entidade, que, de certo modo, administra um dinheiro público, declara como finalidades:

I. O desenvolvimento integral do educando;

II. A formação de educandos com competências fundamentais para o exercício da cidadania, para continuar aprendendo e para progredir no mundo do trabalho;

III. O desenvolvimento de práticas pedagógicas que proporcionem ferramentas para a apropriação de conhecimentos, para uma relação competente com as tecnologias e consolidação de valores e atitudes básicas; 
IV. A formação do cidadão produtivo, que possa contribuir para a melhoria da sua qualidade de vida e da comunidade. ${ }^{17}$

Há ainda, no Regimento escolar da rede, uma orientação quanto aos procedimentos metodológicos, entre os quais se deve incluir, hierarquicamente: a mobilização, a identificação de conhecimentos prévios, a análise de conhecimentos prévios, a tomada de decisão, a problematização (leituras, produções escritas, trabalhos em grupo, aulas expositivas, debates, desafios, experimentos científicos, pesquisas, entrevistas), a sistematização e a avaliação (com base em uma diversidade de instrumentos).

Por seu compromisso social e pelas regulamentações externas, como a da ISO, a instituição escolar vive de um certo rigor quanto a padrões e burocracias. A valorização do professor no SESI é considerável, em termos de salário e condição de trabalho, se compararmos aos padrões da rede estadual de São Paulo, por exemplo.

\section{$\underline{\mathrm{O} \text { desenvolvimento das aulas }}$}

Trabalhei, durante as primeiras aulas, com uma revisão de cálculos aritméticos e algébricos. Durante a revisão mencionada, visando a facilitar a devolução da Sequência Didática de Análise Combinatória, eu pretendi, na medida do possível, desenvolver com os alunos o hábito de formular e validar as ações e a naturalidade ao encarar problemas novos a serem resolvidos.

Para desenvolver o hábito de formular e validar as ações, propus aos alunos questões que deveriam fazê-los refletir sobre técnicas conhecidas, mas não compreendidas na maioria dos casos. Por exemplo, por que todo número elevado a zero é um? Por que, para somar frações de denominadores diferentes, encontra-se o mmc dos denominadores, divide-o pelos denominadores das frações iniciais e multiplica-o pelos numeradores? Por que o produto de dois números negativos é um número positivo?

Os alunos demonstraram grande resistência para buscar o porquê dos procedimentos e respondiam que as regras são assim, os seus professores haviam ensinado essas regras e eles simplesmente aceitavam. Mesmo após as explicações dos "porquês", alguns alunos permaneceram dizendo que "menos com menos dá mais" porque a regra de sinais diz que é assim.

\footnotetext{
${ }^{17}$ Disponível em www.sesisp.org.br/educacao/hArquivo.ashx?Url=10167, visualizado em junho/2014
} 
Acredito que essa postura dos alunos revela o histórico de sua formação, pela qual passaram várias pessoas formulando sentenças matemáticas e pedindo apenas que aceitassem. É claro que eu não poderia mudar-lhes a visão com tão poucas aulas que me estavam reservadas, mas tentei mostrar que decorar e aceitar não são o melhor caminho quando se quer aprender Matemática e desenvolver a habilidade de resolver problemas.

Buscando desenvolver uma certa naturalidade, por parte dos alunos, ao encarar problemas novos a serem resolvidos, eu propus desafios e enigmas. A maioria deles poderia ser resolvida de diversos modos e exigia apenas raciocínio lógico e criatividade.

Apenas a tentativa de desvendar os enigmas já lhes assegurava os pontos de participação e, desse modo, eles não se sentiram pressionados a resolver os problemas. Os alunos se envolveram bastante em atividades desse tipo e chegaram a oferecer soluções bastante originais para os problemas.

Em meio a esse apelo para o uso do raciocínio e da justificativa em Matemática, acabei fazendo uma escolha incoerente. Como na experiência anterior (primeiro momento) não apresentei o conceito de fatorial, senão rapidamente durante a resolução de um exercício, resolvi dessa vez apresentar o conceito de fatorial e solicitar cálculos com fatorial antes de iniciar o trabalho com Análise Combinatória. Isso não fazia nenhum sentido para os alunos, e quando eles perguntavam para que estavam aprendendo aquilo, eu apenas prometia apresentar sua aplicação no próximo conteúdo a ser visto (Análise Combinatória). Hoje considero essa escolha inadequada, pois percebi que os alunos se sentiam frustrados com essa explicação: aprender agora para usar depois. Eles questionavam, com razão, que essa prática ia de encontro ao que eu havia orientado até então - desejar entender os porquês nas aulas de Matemática.

Percebo agora que o cálculo fatorial é uma ferramenta que auxilia na resolução de problemas que envolvem Análise Combinatória e, portanto, a sua aprendizagem deve ser motivada pela Análise Combinatória, e não o contrário.

Assim que me apresentei, havia dito a eles que não haveria prova. Minha avaliação seria feita por outros métodos. Mas, percebi que essa informação, aliada ao fato de eu não ser a professora titular, os deixou acomodados e desmotivados por aprender. Um tempo depois, então, informei que haveria sim uma prova após a Sequência Didática. Novamente, a avaliação (nota) é vista pelos alunos com um valor superior ao do conhecimento, assim como percebi na experiência anterior (primeiro momento). 
Os alunos apresentavam sempre resistência à regras novas (não conhecidas por eles) do Contrato Didático. Uma delas foi a ausência de prova, tive que voltar atrás. Outra regra recusada, porém seguida até o fim, foi a regra da "plaquinha". Para evitar que os alunos interrompessem constantemente a aula pedindo para sair da sala ou que, por outro lado, saíssem sem controle, estabeleci uma plaquinha que seria o seu controle. A saída da sala mediante o porte dessa plaquinha transferiu para eles a responsabilidade e estabeleceu certa organização em sala, uma vez que não poderiam sair dois alunos ao mesmo tempo.

Outra regra causou polêmica. Avisei que os alunos não poderiam chegar atrasados na aula. Assim que entrasse na sala, eu iria trancar a porta e fazer chamada de modo que os alunos atrasados entrariam após a chamada, ficando com falta. Um grupo de alunos se revoltou, dizendo que eu não tinha o direito de fazer isso. A coordenadora da escola interveio dizendo que eu tinha sim essa autoridade. Considerei que esse era um momento de ruptura do contrato, ou seja, o momento de tornar explícitas algumas cláusulas que não eram.

Reservei a aula seguinte para renegociação do contrato. Iniciei inclusive explicando o próprio referencial teórico de Contrato Didático, entre outras coisas, oportunizei que falassem e chegamos a alguns acordos. A própria turma percebeu que a medida, descrita acima, era necessária.

Os alunos da escola estavam acostumados com um padrão de Contrato Didático. Toda regra nova era interpretada pelos adolescentes negativamente, como mais uma regra para limitar sua liberdade e seus direitos. Quando conversamos sobre os motivos de cada regra, a convivência passou a ser mais pacífica e até prazerosa. Os próprios alunos prejudicados com a chamada naquela ocasião se tornaram extremamente participativos e se envolveram ativamente na Sequência Didática.

Cada aluno recebeu uma apostila contendo a Sequência Didática "A cidade de Contagem"18. Os grupos, de 4 a 6 alunos, foram formados para trabalhar durante cerca de 3 aulas na sequência. Durante essas aulas, percorri a sala observando e filmando as tentativas dos grupos de chegar à solução dos desafios. Meu papel, nesse momento, não era dar respostas, mas apenas observar e lançar mais perguntas.

Aplicada a Sequência Didática, seguimos com a etapa de institucionalização do saber. Cada aluno tinha a necessidade de observar, no conhecimento subjetivo que havia adquirido,

\footnotetext{
${ }^{18}$ A Sequência Didática encontra-se na seção 2.2
} 
restrições e generalizações. A formalização do conteúdo permitiria reconhecer no saber o seu caráter universal e sua aplicação a outros contextos.

Os alunos receberam uma nova apostila, na qual os exercícios estavam divididos por tópicos: Arranjo simples, Permutação simples, Permutação com repetição e Combinação simples. Após explicar cada item e apresentar a fórmula correspondente, com base nos desafios que os alunos já tinham solucionado, pedi que resolvessem os exercícios pela fórmula ou pelo raciocínio, como faziam antes.

A maioria dos alunos optou por continuar resolvendo as situações sem as fórmulas, apenas raciocinando sobre as multiplicações e divisões necessárias.

\section{$\underline{\text { A avaliação }}$}

A avaliação é uma parte importante de todo o processo de ensino, mas não é o fim. Esse processo não tem um fim. É um ciclo que parte de uma avaliação (diagnóstica) e prossegue com avaliações regulares que permitem a reconsideração e a reformulação do planejamento. A avaliação contínua alimenta o planejamento, que, por sua vez, não pode ser visto de modo estático.

De acordo com Martins (1997, p. 34),

a avaliação é muito ampla, inesgotável. Avaliamos as mudanças, a participação, o conteúdo, a rotina, o produto e o processo, o exercício da autoridade, as derrapadas autoritárias, os saltos no pensar, as emoções, o desejo...

Ao longo dessa vivência com o projeto de Análise Combinatória, pude perceber, principalmente, o quanto as ferramentas teóricas de que dispomos influenciam na percepção dos fatos e em cada tomada de decisão. Por exemplo, ao perceber a ruptura do Contrato Didático, pude conversar abertamente com eles sobre o que estava acontecendo do ponto de vista teórico. E quando os alunos se recusavam a interpretar a situação a ser resolvida, procurando apenas números a multiplicar, vi claramente que, apesar da devolução, o Contrato Didático antigo prevalecia e a regra era encontrar os dados do enunciado a serem usados.

Pontos positivos e negativos puderam ser ponderados durante o projeto aplicado. Como ponto negativo, podemos citar a limitação do tempo escolar que causou prejuízos para a aprendizagem de alguns alunos que necessitavam de mais tempo para amadurecer os conceitos. 
Em busca de uma avaliação formativa, utilizei vários instrumentos para visualizar o desenvolvimento de cada aluno no desenrolar do projeto: anotações pessoais, exercícios entregues, a própria filmagem e a prova final. Nesta última, as notas foram baixas e revelaram ainda uma certa insegurança de cada aluno ao resolver um problema sozinho. Dos 89 alunos que realizaram a prova, 24 tiraram notas maiores ou igual a 7; 25 tiraram notas entre 5 e 6,9 e 40 tiraram notas menores que 5.

Considerei como avaliação de cada aluno, apesar das provas, o processo vivenciado como um todo, o que me leva a concluir que esse é o melhor jeito de aprender: debruçar-se sobre o problema e, antes disso, tomá-lo como seu.

\subsubsection{Análise dos dados}

Observe a fala de uma aluna referente ao desafio 2:

A1 - Aqui no desafio 2, a gente pensou de duas maneiras: Nessa daqui, a gente pegou os números ímpares, fazendo vezes ele, vezes quatro. Ou então pegamos o 5 (números ímpares) vezes o 4 (algarismos) que dá 20. E a gente não sabe que modo que está certo.

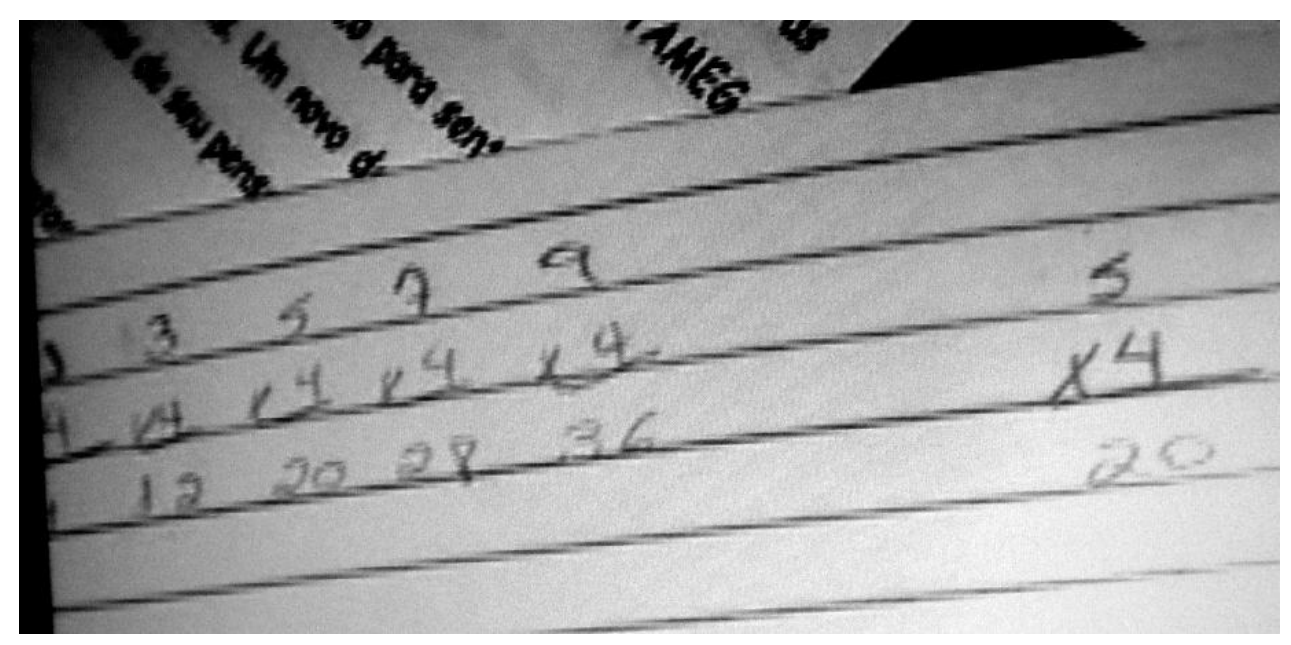

Figura 13- Resolução de um grupo de alunos para o desafio 2

Essa fala e a ilustração evidenciam o que há de mais comum na resolução de todos os desafios. Assim como aconteceu na experiência anterior, os alunos ouviram falar, em algum 
momento de suas experiências escolares, que para resolver problemas de Análise Combinatória precisariam fazer uma multiplicação. Então, em vez de compreender o significado do desafio e tentar resolvê-lo, os alunos partiam em busca de números para multiplicar.

Não sabendo exatamente "o que era para multiplicar", as alunas tentaram duas coisas: Multiplicar cada número ímpar por quatro, pois eram quatro algarismos, e multiplicar 5 (total de dígitos ímpares) por 4 (quantidade de dígitos da senha).

Esse tipo de observação revela coisas importantes sobre o Contrato Didático, pois eles resistiam a encarar o problema no seu significado contextual, queriam apenas encontrar os dados para substituir numa fórmula (a multiplicação, no caso).

Pais (2002, p. 81), ao tratar da ruptura do Contrato Didático, apresenta um exemplo bem conhecido de um problema cujo enunciado apresenta dados sem lógica entre si. O problema é: "Num navio há 26 carneiros e 10 cabras. Qual é a idade do Capitão"? Pais cita uma pesquisa em que grande parte dos alunos, sem perceber a incoerência do enunciado, responde o problema efetuando algum cálculo com os números que aparecem. Para o autor, utilizar os dados do enunciado e realizar uma conta com eles para responder o problema é “quase sempre, uma regra implícita na resolução de problemas de aritmética” (p. 81).

Meu papel ali, então, era de desviar o interesse da fórmula para a resolução do problema e de fazê-los explicar o porquê da multiplicação. Ao mostrar que não basta multiplicar os números que aparecem no enunciado e que nem sempre os números a serem multiplicados estão explícitos causei uma sensação de desconforto nos alunos, acostumados com outro tipo de contrato.

Observe, agora, o diálogo entre mim (W) e dois alunos (A1 e A2) a respeito do desafio 3 da sequência:

A1- São oito letras. Então, no caso, seria fazer oito vezes oito? Oito letras e são oito lugares. Aí daria a resposta 64.

W - "Tá", são oito letras e oito lugares. No primeiro lugar, eu posso pôr quantas letras?

A1 - Oito.

$\mathrm{W}-\mathrm{E}$ no segundo?

A1 - Oito.

W - Então pode ficar, por exemplo, C-C.

A1 - É... Então $8 \times 7,8 \times 6,8 \times 5,8 \times 4 \ldots$

A2 $-8 \times 7 \times 6 \ldots$ Eu acho que vai ser $8 \times 7 \times 6 \times 5 \ldots$ Só que isso oito vezes.

A1 - Oito vezes? [...] 
W - Tenta pensar nessa, do mesmo jeito que vocês pensaram no desafio $1 \mathrm{e}$ no desafio 2.

A1 - Não é oito vezes oito, igual a 64?

W - Pensa com menos letras, gente. Pensa assim, ó... Com ABC, quantas possibilidades teriam? Depois com $\mathrm{ABCD}$, quantas possibilidades?

$\mathrm{A} 1$ - Calma, com ABC ou com ABCD?

Podemos observar vários aspectos desse diálogo. Novamente, os alunos procuram o que multiplicar, talvez já entendendo agora, por ser o desafio 3, porque multiplicar. Eu evito dar resposta, mas busco o tempo todo caminhos para simplificar o problema e fazê-lo compreensível. A questão que fica aqui é: até que ponto essas dicas não reproduz justamente o que estamos querendo evitar - a antecipação do raciocínio que deveria ser do aluno, a interferência na busca que deveria ser dele?

Podemos observar ainda, nas falas dos alunos, questões interessantes de Contrato Didático. Por exemplo:

\footnotetext{
A1 - A prova escrita, professora, vai cair coisa sobre essa historinha? W - Não, é Análise Combinatória.

A1 - Prova dissertativa é sobre Análise Combinatória? É que é muito difícil, né? Muito raciocínio...
}

Ao reconhecer um tipo de atividade diferente do que já tinha visto, o aluno preocupouse com o tipo de avaliação que poderia ser feita. Se o que estavam fazendo era resolver desafios inseridos numa narrativa, sem preocupação com nomenclaturas específicas e fórmulas, o que poderia cair na avaliação? Perguntas sobre a historinha?

Respondi que não. As questões da prova seriam referentes ao conteúdo que estava sendo aprendido de um modo diferenciado, iniciando-se pela resolução dos problemas, como eu sempre explicava.

O aluno logo compreendeu que a prova seria composta por desafios similares aos que estavam resolvendo, possivelmente em outro contexto, outra narrativa, ao que reagiu: "É que é muito difícil, né?" Os desafios que estavam resolvendo agora sem compromisso, poderiam se tornar passíveis de avaliação e isso o preocupou.

Outro exemplo de fala reveladora do Contrato Didático:

A1 - Você tem que pegar quantos tipos de suporte você tem, vezes quantos tipos de sabores vezes quantas coberturas. Vai dar doze maneiras. Doze sorvetes diferentes.

$\mathrm{W}$ - Mas por que doze?

A1 - Porque... 


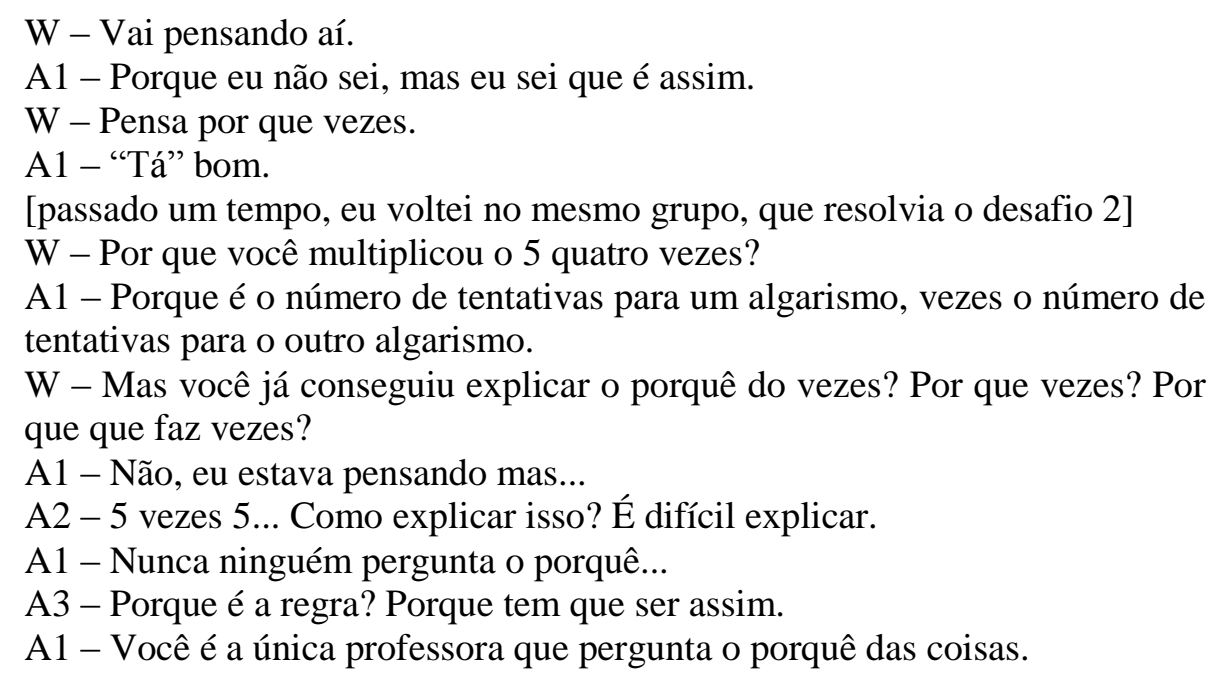

Essa fala dos alunos reforça a existência de um contrato implícito em que se costuma resolver os exercícios sem entender necessariamente o seu contexto e o seu sentido.

Vejamos agora uma fala que caracteriza a situação adidática, ou seja, em que os próprios alunos buscam mobilizar os conhecimentos para a resolução de um desafio novo.

A1 - 7, 8, 9... Não, já perdi as contas. Mas você entendeu? Acho que vai dar mais de doze...

A2 - Vamos fazer assim: aqui, pra cá, aqui, pra cá... [a aluna fazia no papel todas as ligações possíveis]. Dá doze.

A3 - É o meu também deu doze. Duas vezes três seis, vezes dois, doze.

$\mathrm{W}$ - Por que você fez vezes?

A2 - Aqui. Se não tivesse cobertura, teria que levar em consideração o tipo do sorvete e o sabor. Se fosse o tipo e o sabor, teria seis. Porque geralmente, você vai multiplicar as opções do primeiro caso pelo segundo. Então aqui seria duas vezes três, seis. Considerando que tem mais uma... de possibilidade, você teria esse seis vezes as duas vezes da outra opção.

De um modo geral, verificamos nas falas dos alunos que houve a devolução do problema como esperávamos e isso se deve, entre outras coisas, ao contexto que a narrativa trouxe aos problemas.

As atividades para casa também foram analisadas. Nelas os alunos buscaram relacionar a Análise Combinatória com seu cotidiano e seus gostos pessoais. Na atividade 1, eles deveriam lançar um desafio de Análise Combinatória relacionado a alguma experiência já vivida. Apareceu de tudo: moda, turismo, culinária, jogos, entre outros.

Veja um exemplo:

Um dia, havia muitas sobras em casa e tínhamos que acabar logo com elas, portanto, naquele dia, era preciso comer 4 tipos de misturas variadas e 2 
tipos de saladas. Havia macarrão, bife, frango, peixe e batata e 4 tipos de salada: tomate, alface, cebola e beterraba. De quantas formas diferentes era possível montar o prato de sobras?

(Situação problema criada por um aluno)

A resposta foi apresentada corretamente: $\mathrm{C}_{5,4} \times C_{4,2}$

$\mathrm{Na}$ atividade 2 de casa, os alunos deveriam dar um final para a história da Sequência Didática, em que aparecesse um novo desafio. Veja um exemplo:

Marcela chega em sua casa muito contente, pois se saiu muito bem no primeiro semestre da faculdade. Para comemorar, levou sua família para jantar em um restaurante. Sua família tem 5 integrantes e ela reservou uma mesa para 5 pessoas. Quantas são as combinações de lugares possíveis entre seus parentes?

(Situação problema criada por um aluno)

A resposta também foi dada corretamente: $5 !=5 \times 4 \times 3 \times 2 \times 1=120$ combinações

Podemos perceber nesses exemplos mais que uma devolução. Os problemas eram, de fato, dos alunos, pois foram criados por eles, extraídos da própria realidade deles, o que interfere muito na motivação para resolver o problema.

\subsection{Terceiro momento - Escola de Aplicação, 2014}

\subsubsection{Cenário}

Nesse terceiro momento, ano de 2014, eu havia me tornado professora do IFSP Instituto Federal de São Paulo (Ensino Técnico e Superior) e cursava o MPEM - Mestrado Profissional em Ensino de Matemática no IME-USP. Comecei analisar o material que tinha disponível sobre os dois primeiros momentos de aplicação da Sequência Didática e considerei, junto a meu orientador, a possibilidade de analisar um terceiro momento, aplicando novamente a Sequência em uma escola pública.

Tive então a oportunidade de retornar à Escola de Aplicação (EA) da USP para prosseguir com minha pesquisa, na mesma escola em que havia aplicado a Sequência Didática em 2010. Tive o conhecimento de que a escola e, em especial, a área de Matemática participavam do PIBID, pelo qual vários licenciandos bolsistas do IME-USP estavam dispostos a desenvolver atividades diferenciadas com os alunos da EA. 


\section{$\underline{\text { O PIBID }}$}

O Programa Institucional de Bolsas de Iniciação à Docência, PIBID, é um programa federal que concede bolsas a estudantes de cursos de licenciatura para participarem de uma escola da rede pública de ensino no desenvolvimento de projetos e com isso aperfeiçoando-se em sua formação inicial para a docência e contribuindo para com o ensino naquela escola específica.

Além de fornecer bolsas aos estudantes, aos professores coordenadores da Instituição de Ensino Superior e aos professores supervisores da Escola Básica que recebe o bolsista, a Coordenação de Aperfeiçoamento de Pessoal de Nível Superior (CAPES) fornece aos projetos recursos financeiros para custear despesas essenciais à execução dos mesmos, por exemplo, a aquisição de material de consumo para as atividades desenvolvidas nas escolas.

São objetivos do PIBID:

- Incentivar a formação de docentes em nível superior para a Educação Básica;

- $\quad$ contribuir para a valorização do magistério;

- elevar a qualidade da formação inicial de professores nos cursos de Licenciatura, promovendo a integração entre Educação Superior e Educação Básica;

- inserir os licenciandos no cotidiano de escolas da rede pública de educação, proporcionando-lhes oportunidades de criação e participação em experiências metodológicas, tecnológicas e práticas docentes de caráter inovador e interdisciplinar que busquem a superação de problemas identificados no processo de ensino-aprendizagem;

- incentivar escolas públicas de Educação Básica, mobilizando seus professores como coformadores dos futuros docentes e tornando-as protagonistas nos processos de formação inicial para o magistério; e

- contribuir para a articulação entre teoria e prática necessárias à formação dos docentes, elevando a qualidade das ações acadêmicas nos cursos de Licenciatura. ${ }^{19}$

Várias escolas e instituições de ensino superior no Brasil têm se beneficiado desse programa e realizado projetos altamente relevantes, como veem mostrando já algumas publicações. Vejamos agora como o programa é utilizado pela parceria EA e IME-USP.

\footnotetext{
${ }^{19}$ Disponível em http://www.capes.gov.br/educacao-basica/capespibid, visualizado em junho/2014.
} 


\section{$\underline{\text { O PIBID na Escola de Aplicação da USP }}$}

O professor Josenilton Andrade de Franca é um dos supervisores do PIBID na área de Matemática da EA e tem, sob a sua supervisão, oito licenciandos bolsistas. Os coordenadores do projeto no IME-USP, instituição superior no qual os bolsistas realizam o curso de licenciatura em Matemática, são os professores Bárbara Corominas Valério e o professor Antonio Carlos Brolezzi. Esse grupo do PIBID com o qual trabalhei na EA está sob coordenação do professor Brolezzi.

O professor Josenilton já havia trabalhado com o tema Análise Combinatória no $3^{\circ}$ ano do Ensino Médio e pretendia trabalhar até o fim do ano letivo de 2014 o mesmo tópico com alunos do $2^{\circ}$ ano. Essa era a oportunidade de aplicar novamente a Sequência Didática, agora contando com esses novos personagens, os bolsistas.

Meu primeiro encontro com os bolsistas Paulo, Carolina, Roberto, Erika, Gabriel, Sabrina, Jonatas e Jéssica foi no dia 6 de maio de 2014 em uma das reuniões semanais organizadas pelo professor Josenilton.

Nessa reunião estávamos presentes o Josenilton, o Brolezzi, os 8 bolsistas e eu. Logo no início da reunião, foi distribuída a pauta com os assuntos previstos para aquela reunião. Foram tratadas as formalidades com relação a relatórios entre outras e assuntos diversos relativos à formação dos futuros professores, às experiências de ensino vivenciadas na escola e ainda aos próprios conteúdos matemáticos. Foram sugeridos, pelo professor coordenador, apresentações dos bolsistas em congressos e a utilização da verba do PIBID para realização de projetos na escola.

Por orientação do professor Josenilton, os licenciandos bolsistas haviam lido uma pesquisa $^{20}$ sobre experiências de sucesso no ensino de Matemática e apresentavam a cada semana duas dessas experiências, relacionando-as com as observações que fizeram nas aulas deste professor, criticando-as inclusive. Nessa semana, as duas experiências de sucesso estavam relacionadas à estimativa e à utilização do quadro negro e de recursos tecnológicos.

Marquei um novo encontro com os bolsistas, então, para o dia 8 de maio, no qual eles foram entrevistados, detalhando melhor no que consiste o projeto do PIBID na EA e tratando de temas relacionados ao ensino e ao ensino de Análise Combinatória.

\footnotetext{
${ }^{20}$ FONTANIVE et al.(2011)
} 
O professor Josenilton também respondeu a uma entrevista com essa mesma temática no dia 15 de maio. Nesse dia, quando cheguei para entrevistar o professor Josenilton, depareime com o plantão de dúvidas: fiquei por um tempo apreciando esse momento em que mais de 15 alunos estavam voluntariamente no contra turno, tirando suas dúvidas com os 8 bolsistas e o professor Josenilton, o clima era de entusiasmo e desejo de aprender trigonometria, cadernos abertos, folhas de rascunho repletas de desenhos, lousa cheia de esquemas e ciclos trigonométricos.

De acordo com um dos bolsistas, que está há 3 anos no projeto, o papel do bolsista no PIBID é aperfeiçoar-se e trazer novidades para o ensino na escola. Especificamente, na EA, sob supervisão do professor Josenilton, o principal papel deles tem sido observar as aulas para ficar a par do conteúdo e das principais dificuldades dos alunos para, no plantão de dúvidas, realizados às quintas-feiras no contra turno, poder ajudar os alunos com as listas de exercícios. Essa mesma aluna diz que faz parte de suas funções desenvolver projetos que envolvam diretamente os alunos, mas que até agora não teve espaço para isso porque a escola tem muitas atividades.

Outra bolsista, que já trabalhou com outra supervisão na área de Matemática da mesma escola, disse que varia muito a forma de trabalhar com os bolsistas entre os diversos professores supervisores.

De acordo com o professor Josenilton, que participa do programa desde 2011, a principal função do PIBID é melhorar a formação dos bolsistas e a função especificamente do grupo por ele supervisionado não foge do edital - acompanhar as aulas, observar o desempenho dos alunos e propor atividades. Segundo ele, a intervenção do bolsista é mais forte no plantão de dúvidas, espaço onde tem relação direta com o aluno, mas há algumas intervenções pontuais durante as aulas também. O Josenilton cita também a função dos bolsistas de desenvolverem pesquisa (sobre textos didáticos, acadêmicos e documentos da escola), análise das avaliações realizadas pelos alunos e produção de materiais para o ensino, sobretudo listas de exercícios.

No PIBID, os bolsistas devem cumprir 32 horas mensais de atividades, divididas em 8 horas por semana. Na EA, 6 dessas 8 horas devem ser cumpridas na escola. Esse grupo especificamente tem sua carga de 6 horas toda preenchida com atividades bem dirigidas.

O PIBID contribui para a formação dos futuros professores, de acordo com eles próprios, pois ao observar o cotidiano da escola eles podem perceber que cada aluno é 
diferente, e aprender lidar com essa diversidade, além de analisar o tratamento do conteúdo por parte do professor, entre outras coisas. Uma das alunas deu o seu depoimento de que se decidiu ser professora depois de participar das atividades do PIBID, outra declara que ainda não se decidiu quanto a isso:

B - eu acho que a EA é bem diferente das outras. Eu fico muito em dúvida se eu quero ser professora ou não, porque eu gosto muito dessa escola, os alunos são muito bons, a estrutura é muito boa, mas você vai fazer estágio em outras escolas, é tudo uma bagunça, você não tem como controlar a sala, você não pode dar o que você quer, porque a estrutura não permite, os alunos não querem nada com nada. Não sei... são muitos problemas. E aqui a estrutura é muito boa e é por isso que o projeto vai bem.

Para o professor Josenilton, os benefícios do PIBID para os bolsistas são, além dos já citados por eles próprios, os que decorrem do próprio contato com o ambiente escolar e com o conhecimento de seus componentes, das relações que nele se estabelecem, dos problemas que surgem e das estratégias de resolução desses problemas.

Os bolsistas afirmam ainda que o professor supervisor também evolui com a presença deles, pois podem contribuir com opiniões e sugestões sobre as aulas. O Josenilton concorda com isso e afirma a respeito do plantão de dúvidas:

Josenilton - Como você viu ali agora, no plantão de dúvidas, o que é que está sendo mostrado ali? Que na verdade a escola precisa dos bolsistas e [...] se pensar que aquela situação não ocorre agora, só agora, ela ocorre ao longo do ano, toda semana ela ocorre, então toda semana precisaria ter bolsistas aqui, significa que, na verdade além de um projeto, precisava ser um programa de formação. A escola precisa do bolsista, o bolsista precisa da escola, então esse trabalho aí conjunto é que faz os dois crescerem, então uma escola precisa do bolsista por conta disso.

O professor ressalta que é possível fazer um trabalho similar em outras escolas públicas, desde que haja vontade por parte de seus dirigentes. Segundo ele, quando há tentativas desse tipo na rede estadual, acabam se esquecendo do que é mais importante: gente para trabalhar com os alunos. A presença dos 8 bolsistas é fundamental para o sucesso de seu plantão de dúvidas.

Josenilton - Se eu tivesse... só eu professor, não sairia muito do lugar ou faria aula igual da parte da manhã, que não é o interesse deles, eles estão ali cada um com interesse diferente do outro, cada um está com um tipo de dúvida em alguma parte da matéria, resolver um tipo de exercício, o outro é outro tipo, então não adianta, como vou pra lousa pra fazer a mesma coisa pra todo mundo, não dá, então precisa ter gente pra trabalhar com esses alunos, essa é a questão. Então, é possível no Estado? É possível, já tem o PIBID, o PIBID é pra escola pública, então uma das coisas está garantida, aí 
precisa ter a organização na escola para recebê-los e os professores que os recebem têm que ter carga horária pra trabalhar com eles senão não é o bolsista sozinho, o bolsista está ali orientado por um professor.

Para o professor Josenilton, o mais indicado é que o licenciando inicie as atividades do PIBID a partir do segundo semestre de licenciatura, pois o primeiro semestre é o período de adaptação ao curso superior. Para os licenciandos bolsistas, quanto antes se iniciarem as atividades, melhor, para que possam fazer a ponte entre o conhecimento adquirido na Faculdade e o trabalhado na escola. Solicitei então que dessem algum exemplo sobre alguma ponte desse tipo. Eles não lembravam de nenhum exemplo, até que um dos alunos faz um relato do que ocorreu no IME-USP na disciplina de MEB (Matemática na Escola Básica). A professora passou uma questão sobre área de cone e, enquanto todos quebravam a cabeça, ele e outro bolsista do PIBID resolveram rapidamente por regra de três, como o professor Josenilton ensinara para os alunos do Ensino Médio.

\section{Entrevistas com o professor Josenilton e os bolsistas}

Entrevistei os bolsistas a respeito do tema Análise Combinatória e de tópicos de ensino que estão relacionados ao presente trabalho. Antes da entrevista não comentei com eles sobre o tema do meu trabalho e os conceitos da Didática Francesa, para não induzir as respostas. Depois da entrevista, portanto, isso foi feito para que os bolsistas pudessem aplicar a Sequência Didática com os alunos da EA, cientes dos objetivos e referenciais teóricos do presente trabalho.

Nas próximas linhas buscarei sintetizar os resultados das duas entrevistas - com os bolsistas e com o professor Josenilton, supervisor dos bolsistas na escola.

Parte dos bolsistas já haviam tido contato com o tema Análise Combinatória no IMEUSP nas disciplinas de Estatística I e MEB (com a referência CERRI, DRUCK e PEREIRA, 2012), mas ainda assim, alegaram ter dificuldades com esse conteúdo. Uma das bolsistas declarou que não sabe avaliar se os alunos da EA têm muita ou pouca dificuldade em Análise Combinatória, pois ela mesma tem dificuldade com esse tema. Durante a entrevista, o professor Josenilton afirmou que Análise Combinatória é o tema mais difícil do Ensino Médio, tanto para ensinar como para os alunos aprenderem.

Josenilton - [Análise Combinatória é] muito mais difícil que Trigonometria, Trigonometria não é difícil, ela só tem muitos conceitos, símbolos que o aluno não está acostumado, radiano... Agora mesmo eu estava ali [no plantão 
de dúvidas] e o aluno perguntou: Para que eu quero radiano? Para que eu uso isso? Por que não posso ficar só com o grau? É muito mais abstrato, as dificuldades são distintas. Em Análise Combinatória, a grande dificuldade é assim: se a contagem é indireta você fica sempre se perguntando: "Será que está certo? Será que esta quantidade que encontrei é isso mesmo? Não consegue contar, é difícil ele ter a certeza de que aquilo é aquilo mesmo, não tem uma formulazinha fácil e pronto. Às vezes ele tem que juntar vários raciocínios e dá um resultado; às vezes, faz de outro, dá outro: qual que é o certo? É bem difícil, desde que você já queira enfrentar as dificuldades. Eu posso dar um curso de Análise Combinatória extremamente fácil. Eu poderia pegar estas dificuldades, colocar embaixo do tapete e falar pra você, olha como a Análise Combinatória é fácil, você ia acreditar que realmente é fácil, porque eu só te mostrei as coisas simples, bem simplesinhas, exemplos mais simples, os exercícios mais banais e você conclui que tudo é muito fácil, mas não é assim, não é desse jeito.

De fato, tenho observado grande dificuldade por parte de professores para lidar com Análise Combinatória. Pois esse é um dos conteúdos do Ensino Médio que mais envolve abstração e diferentes modos de raciocínio, de modo que alguém, ainda que tenha feito muitos exercícios desse tema, sempre pode se surpreender com um novo desafio. É difícil para o professor fazer com que o aluno entenda o princípio multiplicativo e também é difícil demonstrar total segurança com o conteúdo por causa dessa diversidade.

Aprender Análise Combinatória sem fórmulas é muito melhor, na opinião dos bolsistas. Segundo eles, há conteúdos em que as fórmulas são indispensáveis, esse não é o caso de Análise Combinatória. No entanto, complementam, se a escola tem como objetivo preparar os alunos para o vestibular, é importante que se ensine as fórmulas. O professor Josenilton, em sua entrevista, também cita a importância da fórmula para o vestibular, entre outros motivos.

Josenilton - É possível explicar Análise Combinatória sem as fórmulas clássicas, a fórmula de Arranjo, a fórmula de Combinação, de Permutação, de Permutação com repetição. É possível, tudo isso é simplesmente o princípio multiplicativo, é aplicar o princípio multiplicativo, então é possível.... Aí você fala, você faz isto? Faço em termos, [...] nós começamos com o princípio multiplicativo, resolução dos problemas e tudo mais e a partir daí nós vamos chegando às fórmulas. Acho importante falar [de fórmulas], a fórmula como o próprio nome diz, é simples e é aquilo que você estava desenvolvendo, então você precisa sintetizar às vezes, e em algumas situações em que a fórmula vai agilizar algumas coisas, ela foi feita pra isso, a partir dali eu consigo ganhar agilidade, ganhar tempo na resolução de alguns problemas, resolveria de outra forma? Resolveria, mas se eu posso ter uma maneira mais rápida de fazer, porque não... e as vezes o aluno também se depara num vestibular com questões em que a fórmula é posta explicitamente, de repente ele nunca viu aquilo, ele não vai fazer o exercício 
porque ele não aprendeu, ele não viu aquilo, não se familiarizou com aquela simbologia toda, isto pode trazer alguma dificuldade pra ele, então é possível ensinar Análise Combinatória sem fórmula? É claro que é. É bom fazer só assim? Eu acho que não é bom, acho que tem que sintetizar depois.

Além da necessidade propedêutica das fórmulas, foi apresentada pelo professor Josenilton uma necessidade pedagógica de sua apresentação na escola, a necessidade de síntese, de agilidade e, poderíamos acrescentar, de generalização e conferência de status para o conhecimento. Isso tudo caracteriza a etapa de institucionalização que, de acordo com Brousseau, é a última etapa de uma situação adidática. Desse modo, as fórmulas seriam essenciais não apenas para que o aluno passe em um exame vestibular, mas para que seja capaz de sintetizar e generalizar aquele conteúdo.

Questionei professor e bolsistas também a respeito do tempo escolar, uma questão que tem muito me inquietado no decorrer dessa pesquisa. O Josenilton disse que na EA os alunos de Ensino Médio têm 4 aulas por semana, sendo 2 de sua frente e 2 da frente do professor Ernani, totalizando $3 \mathrm{~h} 20$ de Matemática por semana. Comentou que, pelo curto tempo, é preciso tomar 2 decisões: que conteúdos abordar e a que nível de profundidade abordar. Ao término de um tópico nem todos alunos aprenderam do mesmo modo, uns aprenderam mais outros menos, mas é preciso avançar, retomando posteriormente o que for necessário em recuperações, plantões de dúvidas e até nas próprias aulas. Essa defasagem de uns com relação a outros nem sempre ocorre por dificuldade, alguns alunos não querem mesmo aprender determinado tópico e "se fecham" para ele. Desse modo, não adiantaria ficar insistindo num mesmo tópico até que todos aprendessem.

Os bolsistas concordaram entre si que há muito conteúdo nos currículos oficiais de Ensino Médio e que isso atrapalha o andamento das aulas. Todos apoiaram a ideia de que é preciso sim fazer uma lista de prioridades. Eles disseram que as escolas devem fazer algumas escolhas, pois o conteúdo é muito extenso. A EA, por exemplo, que oferece 14 disciplinas aos alunos do Ensino Médio, optou em tirar do currículo os números complexos e trabalhar melhor Matemática Financeira. Os bolsistas demonstraram valorizar como critério para a seleção dos conteúdos a aplicabilidade no cotidiano dos alunos.

Segundo um dos bolsistas, não é tão importante aprender volume de pirâmide e de tronco de pirâmide. Em lugar disso, deveria se trabalhar melhor as operações básicas e juros, conteúdos que serão usados não "apenas no vestibular", mas no cotidiano de todos, mesmos 
dos que seguirão carreira na área de humanas. Para outra, Análise Combinatória é muito mais importante que volume de pirâmide, porém não mais importante do que aprender juros.

Podemos perceber amplamente em nossa sociedade o quanto é comum a tendência de atribuir maior valor aos conhecimentos aplicáveis. Se pensarmos na característica imediatista da geração atual, como já mencionada na primeira seção deste trabalho, podemos acreditar que essa tendência é ainda maior entre os estudantes de hoje.

A preocupação do professor em relacionar o conhecimento ao cotidiano é legítima. $\mathrm{O}$ presente trabalho segue também nessa linha. No entanto é preciso tomar o cuidado de preservar a educação de uma visão estritamente pragmática ou imediatista. Ou seja, se aprender calcular juros e realizar as quatro operações básicas for necessário em algum momento na vida de uma pessoa, ela poderia aprender essas coisas não necessariamente com a ajuda da escola. Já o papel da escola vai além de apresentar técnicas. Nela deve ser garantida a oferta de oportunidades para que se desenvolvam as habilidades de crítica e raciocínio. É preciso dar acesso ao conhecimento que dificilmente se apresentará diante do aluno fora dos muros da escola.

Questionei, tanto com os bolsistas, quanto com o professor Josenilton, a respeito daquela cláusula que costuma aparecer nos contratos didáticos: resolver exercícios de Matemática implica em escolher números para aplicar em uma fórmula pronta, no caso de Análise Combinatória, números a serem multiplicados. Ao formular a pergunta, no entanto, não citei a expressão "Contrato Didático", apenas citei esse "costume" comum entre os alunos.

O professor Josenilton reconheceu que isso acontece com grande frequência e que uma pergunta que aparece muito durante a resolução de exercícios de Análise Combinatória é “Somo ou multiplico?" E por mais que se explique, fazendo uso da árvore de possibilidades, o princípio multiplicativo, alguns continuam sem compreender quando devem somar e quando devem multiplicar.

Isso é de fato muito comum, também na opinião dos bolsistas, e ocorre porque os alunos não têm o hábito de raciocinar. Para não deixar a questão em branco eles agem dessa forma, não apenas em Análise Combinatória, mas qualquer que seja o conteúdo. Um dos bolsistas disse que costuma chamar de "decoreba" a atitude dos alunos em desejar decorar fórmulas e procedimentos em vez de aprender o conteúdo. Outros disseram que isso não ocorre apenas no Brasil, ou que não ocorre apenas no ensino de Matemática. 
A frase "os alunos não têm o hábito de raciocinar" nos leva a pensar "Não seria a escola responsável por desenvolver esse hábito?” Continuarei, então, acreditando que essa é uma cláusula implícita de um Contrato Didático que não valoriza o raciocínio, de modo que o aluno pode alcançar sucesso apenas memorizando procedimentos.

Perguntei a todos (professor e bolsistas) a respeito de outra cláusula do Contrato Didático, novamente sem mencionar esse termo: “Os alunos costumam fazer apenas as atividades que valem nota?"

O Josenilton respondeu que isso é relativo. Como em todas as escolas, há os alunos que se interessam por Matemática e os que não se interessam. E, além disso, os alunos da EA precisam mesmo fazer escolhas, já que são muitas disciplinas e muitas atividades.

Segundo os bolsistas, isso inclusive aconteceu numa lista de exercícios que passaram com um exercício extra. Pouquíssimos fizeram esse exercício, que não valia nota. Na EA, disseram, o caso é ainda mais grave. A maioria dos alunos atribui valor apenas para as atividades do terceiro trimestre. Como já havia escutado o professor Josenilton comentar o mesmo, perguntei se o terceiro trimestre tinha peso maior nas notas, ao que uma das alunas respondeu:

C - Não é o peso, é que o esquema da escola é assim. Se o aluno não se esforçar no primeiro trimestre, ele pode ficar sossegado porque se ele se esforçar no último, compensa e já era... Então é assim: a estrutura de avaliação da escola que faz acontecer isso.

Novamente uma frase dita esconde a própria ideia de Contrato Didático: “A estrutura de avaliação da escola que faz acontecer isso." O valor que o aluno atribuiu ou não à atividade, às notas e ao conhecimento decorre de um contrato implícito totalmente conhecido dos alunos.

Um dos bolsistas afirmou: os poucos alunos do Ensino Médio que não estão preocupados apenas com as nota e sim em aprender são aqueles que irão prestar vestibular e por isso preocupam-se em aprender.

Sem usar o termo "devolução" perguntei sobre estratégias para que ela ocorra.

B- Eu acho que primeiro, o aluno tem que entender o problema. O exercício está ali no livro e eles não entendem o que está falando lá. Eles colocam uma bola lá dentro de um cilindro com água, quanto que vai ser o volume... Eles não entendem. Não entendem. Não faz parte do mundo deles.

W- E se fosse concreto? Uma pirâmide mesmo, uma esfera real... 
B- Eu acho que ia ser mais fácil pra eles, porque eles iam ter que entender para depois responder.

A- Você corre atrás a partir do momento que você gosta da matéria. Que nem, a gente está fazendo Matemática, a gente gosta de Matemática. Os alunos não gostam de Matemática, eles não vão se interessar por nada.

D- Os alunos nem sabem o que é Matemática. Eles acham que Matemática é só ir calculando...

Nesse breve debate, eles acabaram ressaltando os fatores que mais impedem a devolução nas aulas de Matemática: exercícios difíceis, fora da realidade deles e a própria falta de gosto de alguns com relação à matéria, ou a falta de entendimento com relação ao que seja Matemática. A essa altura perguntei se é possível despertar esse interesse ou fazer com que os alunos entendam o que é Matemática e eles disseram que naquela estrutura escolar, isso não é possível, sugeriram que com a quantidade de matéria que os alunos têm no Ensino Médio, não sobra tempo para investir tanto em uma matéria apenas.

O professor Josenilton afirmou que não tem sido comum os alunos perguntarem para que servem os conteúdos matemáticos, mas alguns perguntam - ou querendo saber alguma aplicação, ou querendo saber para que irão usar. Os bolsistas garantem que quando os alunos estão perguntando "Para que serve esse conteúdo?" Eles não estão querendo saber uma aplicação prática qualquer daquele conteúdo, mas uma aplicação na própria rotina deles, eles querem saber por que eles estão aprendendo aquilo.

Os alunos perguntam por que estão aprendendo determinado conteúdo porque é natural para o ser humano realizar atividades, movidos por suas motivações e necessidades ${ }^{21}$. Portanto, ao preparar um meio que favoreça a aprendizagem o professor deve pensar em estratégias não apenas para que o aluno compreenda o conteúdo, mas que antes disso sinta necessidade de compreendê-lo. Os bolsistas e o professor Josenilton demonstraram um pensamento condizente com esse.

Perguntei que exemplos dariam, caso algum alunos lhes perguntasse "Para que serve Análise Combinatória?" e os exemplos dados pelos bolsistas foram: descobrir uma senha de um celular, entender as possibilidades de ganhar na Mega Sena. O Josenilton respondeu que é importante para Análise Estatística, em termos profissionais, os alunos poderão utilizar em

\footnotetext{
${ }^{21}$ (DANIELS, 2003) ao explicar sobre a teoria da atividade de LEONTIEV e VIGOSTSKI, distingue motivo e necessidade, porém os apresenta como mutuamente implicados e como causa da atividade.
} 
empresas na produção de peças ou análise de qualidade. Deu alguns exemplos também mais relacionados ao cotidiano como citado:

Josenilton- "Olha, como é que está a quantidade de números de telefone, celular? Vou aumentar um dígito, e aí o que acontece?" "Olha, já estão se esgotando as combinações possíveis de placas de carro." Vou citar alguns exemplos de algumas contagens que eles podem fazer, senhas... "Ah, preciso montar, fazer uma senha com oito dígitos do banco, quantas senhas esse banco consegue?" "Porque está aumentando o número de dígitos nas senhas? Antes tinha uma senha com quatro...” então, alguns exemplos aí.

Os bolsistas se mostraram convencidos em vários momentos de que o ensino envolvendo atividades mais práticas e materiais concretos proporciona maior aprendizado. Então perguntei se é possível conduzir o ensino dessa forma para o tema de Análise Combinatória.

W- Mas isso se aplicaria só para Geometria? Porque os exemplos que vocês deram de objetos, coisas concretas foram em Geometria. E em Análise Combinatória, por exemplo, seria possível ensinar dessa "forma concreta" será? Ou que se aplicasse mesmo à vida dele, ao cotidiano dele, alguém consegue pensar numa possibilidade?

A- Pedir para a sala pensar numa determinada situação. Por exemplo, pega uma situação do cotidiano e joga para a sala e todo mundo começa comentar, cada um dá sua opinião.

$\mathrm{W}$ - Do cotidiano deles? Tentar extrair deles o problema, é isso?

E- Tem uma aula que o professor pergunta quantos caminhos tem para chegar de uma carteira da frente até outra de trás, caminhado para a direita e para trás. Eu achei bem legal.

D- Tem outra que é bem comum: perguntar de quantos modos dá para fazer um grupo de tantas pessoas dentre eles...

B- Nunca vi aqui na escola, mas chama os alunos na frente para eles trocarem de lugares para ficarem enfileirados.

Uma estratégia eficiente no ensino de Análise Combinatória e que serve para muitos conteúdos da Matemática (não todos), de acordo com o professor Josenilton, é "tentar colocálos nos exemplos".

Josenilton- esses [exemplos] que eu te passei é do dia a dia deles, o telefone, o carro, quantas placas tem, é o dia a dia de todo mundo. Na verdade, às vezes a gente quer mostrar que a própria sala a gente pode utilizar pra dar os exemplos e aí tentar motivá-los mais por isso, então, a minha sala lá tem 30 alunos, eu preciso montar uma comissão pra representar os alunos no conselho de escola, e esta comissão é tal...se montar chapa para o grêmio que vai concorrer quantas chapas distintas eu consigo? 
O Josenilton ao longo de sua experiência foi mudando o seu modo de ensinar. Ele disse que todo professor começa a carreira com uma certa insegurança e portanto se baseia muito em livros didáticos, faz tudo do jeito que está no livro para não errar. Aos poucos a insegurança vai desaparecendo, mas todo ano é preciso dar uma revisada no conteúdo para pensar o melhor jeito de explicar de convencer o aluno de que a fórmula é aquela mesmo. "Porque se fosse para o professor apenas explicar como está no livro, chegar na lousa e expor o conteúdo, não precisaria de professor", disse ele. E acrescentou: "Sempre devo pensar sobre alguma maneira de eu explicar isto melhor. Não é tão tranquilo assim se você pensa que alguém que está do teu lado tem que entender."

Por último, os bolsistas fizeram uma observação sobre trabalho em grupo, o que de certo modo está relacionado às concepções de aprendizagem de Vigostski, que adotamos. Eles consideram muito importante os trabalhos em grupo. As listas de exercícios passadas pelo professor Josenilton são individuais, mas eles se comunicam entre eles para resolver os exercícios, os que sabem mais ajudando os que sabem menos. Na opinião de um deles, um trabalho em grupo mais formal seria inadequado, pois o tempo escolar faria com que eles se subdividissem, cada um fazendo uma parte da lista.

\subsubsection{Análise dos dados}

Ao analisar os dados deste terceiro momento podemos fazer relações dos acontecimentos, não apenas com o referencial teórico, mas também com o segundo e o terceiro momentos e com as concepções e expectativas de quem aplicou a Sequência Didática- os bolsistas da Escola de Aplicação.

Até o segundo momento de aplicação do projeto, verificamos que houve uma devolução parcial da Sequência Didática, pois os alunos se sentiram motivados em prosseguir com a narrativa e buscar respostas para os desafios, mas não se sentiam totalmente responsáveis pela resolução correta de cada desafio, já que aceitavam uma cláusula implícita do Contrato Didático de realizar operações sem compreendê-las, o que provavelmente não fariam se fosse uma situação não-didática.

Acreditamos que se a devolução é totalmente efetiva, a fase de ação surge naturalmente, o que não ocorreu com os alunos até o segundo momento deste projeto, a não 
ser no primeiro desafio. Buscando substituir os números em uma fórmula, os alunos pulavam a fase de ação tornando deficiente a fase de formulação.

Buscando amenizar esse desvio, nesse terceiro momento, algumas alterações foram feitas:

- Os alunos convidados para participar da atividade não haviam visto o princípio multiplicativo ainda como conteúdo escolar.

- Por ser a atividade realizada no contra turno, com alunos que se voluntariaram e sem valer nota, os alunos presentes não estariam ali por outro motivo senão aprender Análise Combinatória (próximo tema a ser estudado em suas aulas de Matemática).

- Letras e números concretos (emborrachados) estavam disponíveis para que os alunos manipulassem, com a hipótese de que isso enriqueceria a fase de ação.

- Fomos aplicar a Sequência Didática sem saber quantos desafios os alunos iriam resolver. Tínhamos 2 horas e não sabíamos a quantas conclusões os alunos chegariam nesse tempo- diferente do que ocorreu nos demais momentos em que estipulávamos o número de desafios a serem resolvidos num determinado tempo.

No dia 11 de setembro de 2014 fiz uma apresentação formal para os bolsistas dos objetivos e referenciais teóricos do meu projeto relacionando-os com cada tópico abordado na entrevista e com as respostas por eles dadas; entreguei para cada um deles uma cópia da Sequência Didática “A cidade de Contagem”, a qual iriam aplicar.

No dia 18 de setembro de 2014, quatro alunos do segundo ano do Ensino Médio J, K, L e M; três bolsistas B, D e H e eu nos reunimos em uma sala para resolverem a Sequência Didática "A cidade de Contagem", ao lado da sala em que ocorria o convencional plantão de dúvidas e onde permaneceram os demais bolsistas para tirar dúvidas dos demais alunos que aparecessem. A proposta para esse terceiro momento era de que os três bolsistas desempenhassem o papel de orientadores da Sequência Didática, estando eu presente apenas para observar e fazer os registros. No entanto, algumas intervenções de minha parte também foram feitas durante a aplicação da sequência.

$\mathrm{Na}$ última aula que esses quatro alunos haviam tido com o professor Josenilton, este fez uma introdução a respeito do tema Análise Combinatória, tema ao qual iria dar continuidade na aula seguinte, e lançou o convite para todos os alunos do segundo ano comparecerem na escola quinta-feira no contra turno para aprenderem mais sobre esse tema. 
Como essa atividade em si não estaria valendo nota alguma, podemos considerar que J, K, L e M eram alunos que estavam interessados em aprender, não sabemos se pelo conteúdo ou se para melhorar o rendimento escolar. Durante a situação, perguntei se eles se consideravam bons alunos em Matemática. $\mathrm{J}$ respondeu que não era, mas que os outros três eram muito inteligentes. K disse que tem interesse em prosseguir os estudos na área de Matemática após o Ensino Médio.

\section{$\underline{\text { Desafio } 1}$}

Os alunos e os bolsistas sentaram em círculo e $\mathrm{J}$ realizou a leitura da narrativa até o primeiro desafio. Após a leitura, fez-se silêncio, todos estavam concentrados em resolver o problema e começaram a escrever alguma coisa. Após aproximadamente 1 minuto, $\mathrm{K}$ disse: “É doze.... Está certo?” E B perguntou: “Todos já chegaram nesse resultado?” M pediu para esperar pois estava terminando de resolver. Enquanto isso J, K e L começaram folhear o texto, ao que parece também tinham chegado à mesma conclusão.

Passado mais um tempo, a bolsista B perguntou: "E da onde vocês tiraram esse resultado?” A aluna $\mathrm{J}$ explicou com suas palavras e mostrou a árvore de possibilidades. B respondeu: "Está bom, está certo".

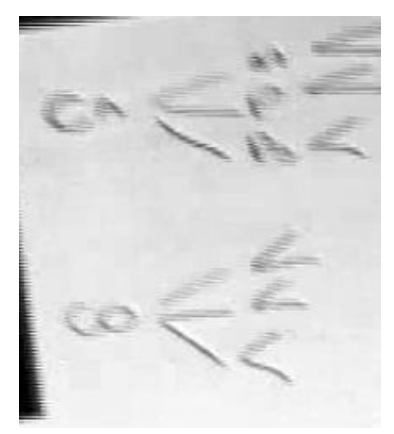

Figura 14- Resolução da aluna J para desafio 1

Então o aluno M se manifestou "Se metade dos sabores já são 6, então é 12." M também mostrou um esquema, mas não se tratava de uma árvore de possibilidades. No esquema ele contara apenas metade dos casos, os sorvetes com casquinha como ele mesmo disse. “Como eu estou descobrindo aqui, metade dos sabores já são 6, então é 12". 


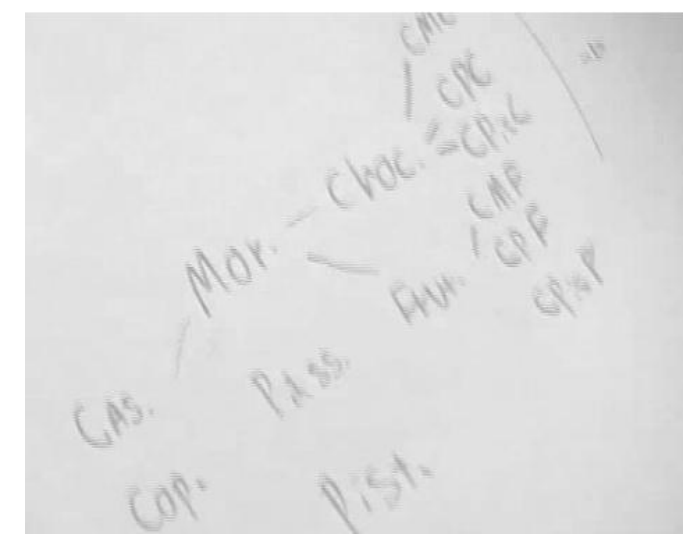

Figura 15- Resolução do aluno M para o desafio 1

$\mathrm{Na}$ aula introdutória de Análise Combinatória, o professor Josenilton havia mostrado a árvore de possibilidades. A aluna $\mathbf{J}$ conseguiu utilizar esse recurso para representar todas as combinações de sorvete. M parece ter tentado utilizar esse recurso, mas o que fez de fato foi ligar casquinha, um sabor e uma cobertura; casquinha, outro sabor e outra cobertura; e assim contar as 6 possibilidades de sorvete com casquinha.

O que houve aqui no desafio 1, portanto foi nitidamente uma fase de ação, pois baseados em tentativas (a lista ou a árvore de possibilidades), os alunos conseguiram contar todas as opções de sorvete. O número pequeno de possibilidades permite que o aluno resolva esse primeiro desafio por ação, sem ter a necessidade de formular um princípio mais geral, no caso o princípio multiplicativo.

Então eu peço aos bolsistas que induzam os alunos a uma generalização ainda no desafio 1, mas os alunos não apresentaram nenhuma proposta.

B- Se fossem, sei lá, 6 sabores? O que vocês iam fazer? Vocês iam fazer a árvore para os seis sabores? Vocês têm que achar um jeito "poxa" de ficar mais fácil, aí não tem que fazer a árvore toda hora.

Aluna K- Deve ter um jeito comum de resolver eles. Por exemplo, o tanto de sabores, ou os dígitos no próximo desafio.

B- Vamos fazer o próximo, aí vocês vão pensando, vendo se vocês conseguem achar uma regra.

\section{Desafio 2}

A aluna $\mathrm{J}$ leu o desafio 2. Novamente cada um se concentrou em sua folha e começou pensar e escrever individualmente. É inviável resolver desafio 2 por meio de contagem direta 
das possibilidades, portanto ele gera naturalmente a necessidade de criar uma estratégia indireta de contagem, possibilitando dessa forma a fase de formulação.

Pouco tempo após a leitura do segundo desafio, o bolsista D interveio:

D - Pensa em uma possibilidade de senha. Fala uma senha que é possível de ser.

Aluna L - 1-1-1-1

B - Vamos ler o enunciado direito "Lembra apenas que a senha tinha 4 dígitos numéricos e que eram todos ímpares". Vocês lembram o que é ímpar?

Aluno M- 1, 3, 5, 7 e 9. Ou seja, em cada um dos 4 espaços nós temos 5 opções de números.

Aluna K - Então isso dá 20.

D- Vocês podem usar o mesmo método que no anterior, né?

Aluna K- É. Só que dá mais trabalho.

A aluna K lançou a primeira tentativa de resposta, 20. Mas é interessante notar que esse resultado apareceu também nos outros momentos de aplicação do projeto como resultado do produto de 4 (número de dígitos da senha) e 5 (número de possibilidades para cada dígito). Quando M disse que são 4 espaços para 5 opções de números, K rapidamente calculou $4 \times 5$. Infelizmente não questionamos a aluna $\mathrm{K}$ a respeito dessa resposta, a qual também ela não continuou mantendo, então não podemos dizer por que associou a resolução desse desafio a uma multiplicação.

$\mathrm{Na}$ transcrição acima, D sugeriu que usassem o mesmo método que usaram para resolver o desafio 1 se referindo à árvore de possibilidades, mas $\mathrm{K}$ intuitivamente percebeu que são muitas opções para se registrar em uma árvore. Essa seria uma boa motivação para que os alunos sentissem a necessidade de realizar uma formulação. Antes disso, no entanto, resolveram aceitar a sugestão do bolsista, analisando algumas tentativas de senha (fase de ação).

O que não acontecera nos demais momentos de aplicação do projeto, finalmente aconteceu neste terceiro momento. A devolução do desafio 2 foi completa, pois os alunos, sentindo a necessidade de resolvê-lo, não se contentaram em aplicar uma possível fórmula pronta, mas começaram a pensar listando algumas possibilidades e buscando alguma generalização. Isso levou bastante tempo, como veremos a seguir.

Todos os alunos ficaram envolvidos no desafio 2 por mais de 30 minutos, mesmo depois de terem encontrado a resposta, pois estavam também buscando uma solução geral (formulação), bem como compreendendo o porquê das operações utilizadas (validação). 
Percebemos que isso não poderia ter acontecido no primeiro momento de aplicação do projeto, no qual demos apenas 8 minutos para a realização do desafio 2.

A aluna L diz: "São mais de 20" e lista algumas possibilidades. K trabalha novamente com árvore de possibilidades.

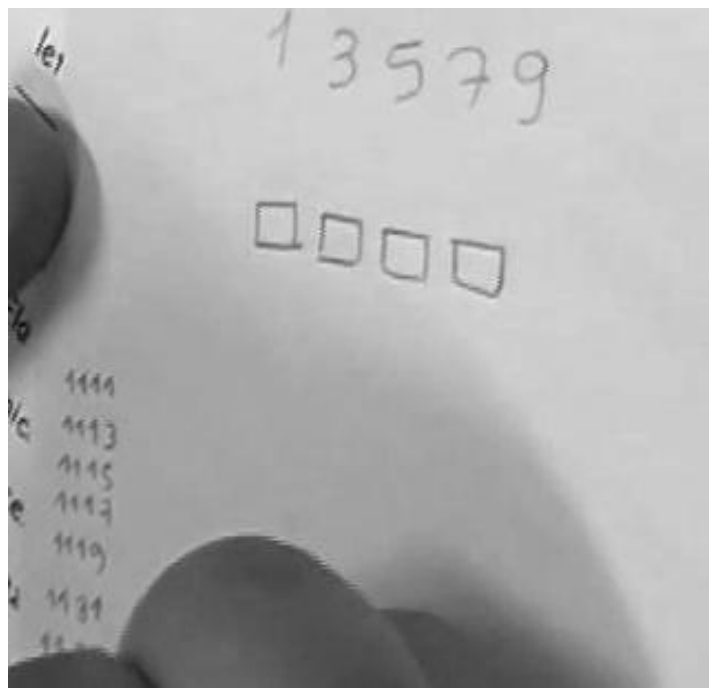

Figura 16- Resolução da aluna L para o desafio 2

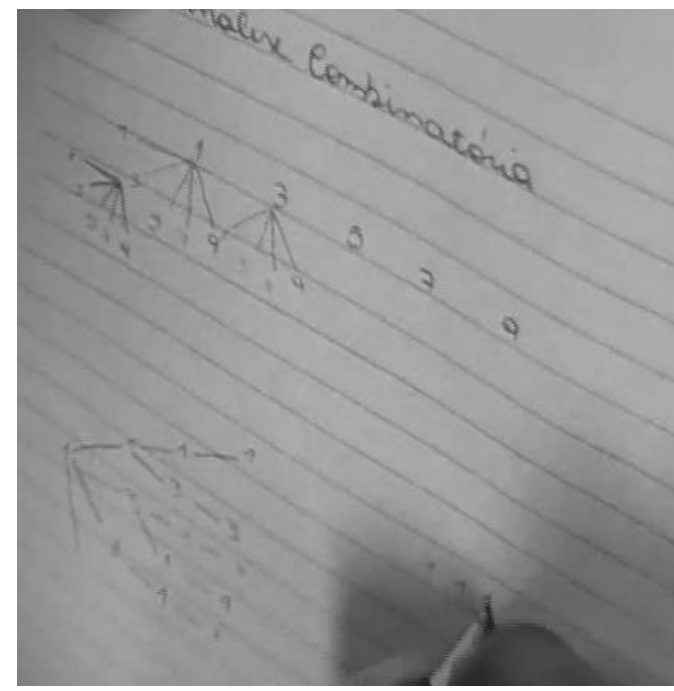

Figura 17- Resolução da aluna K para o desafio 2

Solicitei à aluna $\mathrm{J}$ que mostrasse algumas senhas com os números em emborrachado. Trocando os números, $\mathbf{J}$ mostrou 10 possibilidades com os números e declarou: “Ah, podem ser infinitos! Esse pode ser um, esse pode ser outro, esse pode ser outro... Tem bilhares”. 
Então, 7 minutos após a leitura do desafio, M chegou a uma conclusão.

Aluno M- Eu acho que eu sei. É uma hipótese. Mas, pela sequência de números aqui dá pra fazer 5 mudando só um dos números. Aí como tem 5 números que a gente pode usar e cada um deles vai dar 5. Se fizer 25 por 25 vai dar alguma coisa perto?

$\mathrm{W}-25$ vezes 25 ?

Aluno M-É.

W- Explica de novo.

Aluno M - Eu também não entendi muito o que eu fiz, mas eu sinto que está certo. Porque aqui a gente tem um número, aqui também, aqui também Isso faz com que cada número que a gente muda tenha 5 opções diferentes. $\mathrm{E}$ como a gente tem 5 opções para mudar e cada um tem 5 opções diferentes. Então a gente faz 25 por 25 .

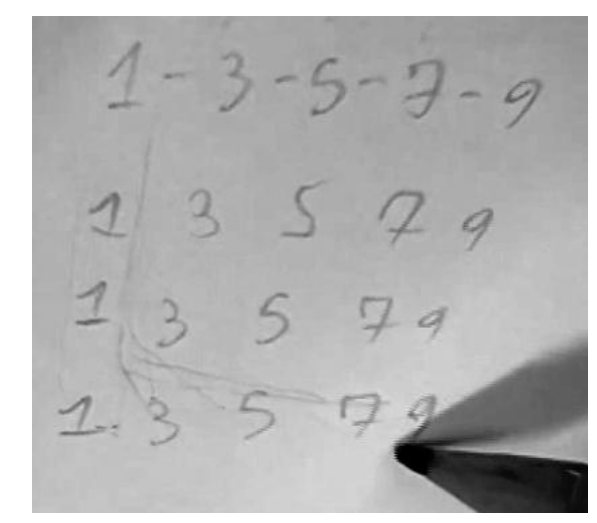

Figura 18- Resolução do aluno M para o desafio 2

Ao explicar, M passava o lápis por cima dos traços de seu esquema, que não era uma árvore de possibilidades. Apesar de seu esquema não ajudar muito na hora da explicação, foi suficiente para que ele resolvesse o desafio e demonstrasse total convicção de sua resposta. D convenceu $\mathrm{M}$ de representar as senhas com uma árvore de possibilidades, então $\mathrm{M}$ começou se empenhar nessa tarefa.

A aluna L listou todas as 25 possibilidades começadas em 1-1 e as agrupou de 5 em 5 de acordo com a variação do $3^{\circ}$ dígito. Antes de pensar nos esquemas, esta seria a forma mais natural de se contar as possibilidades, o que nos mostra mais uma vez a devolução realizada: aceitação do desafio, entendimento do mesmo e necessidade de resolvê-lo - ainda que não tenha pensado em realizar os esquemas, L listou todas as possibilidades. Se continuasse pensando sobre essa lista, ainda que não a continuasse, L poderia perceber a necessidade de multiplicar o 25 encontrado por 5 e o produto por 5 novamente. 


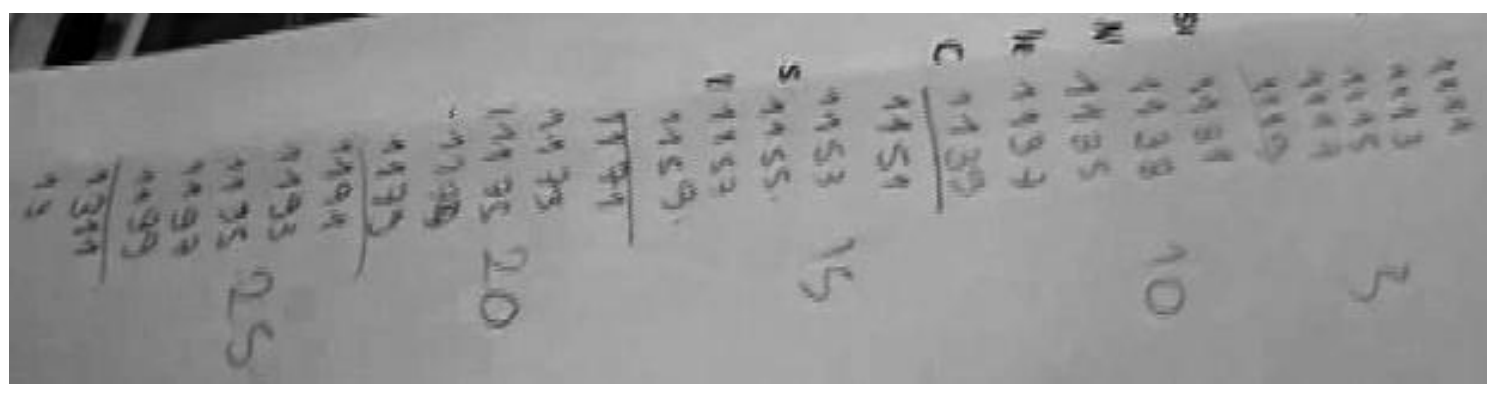

Figura 19- Resolução da aluna L para o desafio 2 (continuação)

No entanto, ao contrário de M, L estava totalmente insegura. Talvez por ter visto seus colegas fazendo esquemas ou por ter ficado constrangida em sua explicação, L desconsiderou tudo o que tinha feito.

Aluna L- Eu peguei lá, fiz tudo com 1. Eu fiz... Eu não sei explicar. D - Você fez todas as possibilidades que começam com 1 ?

Aluna L- É até a terceira casa. Mas eu acho que está errado (esconde a folha). Deixa eu apagar.

B- Não apaga! Não apaga o que você fez!

Aluna L- Não, apago sim.

B- Já pensou se depois você percebe que estava certo?

Aluna L - Mas não está certo.

Enquanto $M$ estava seguro de um raciocínio totalmente indireto, L não conseguia acreditar em sua trivial lista. L a partir daí esteve insegura durante toda a aula evitando mostrar o seu raciocínio, apesar de parecer interessada em querer saber a resolução dos desafios. M, por sua vez, não quis explicar sua resolução na lousa, pois disse que primeiro ia tentar explicar a si mesmo.

Enquanto isso, as outras alunas $\mathbf{J}$ e $\mathrm{K}$, separadamente, tentavam resolver o problema explicando seus raciocínios aos bolsistas. Já havia se passado 13 minutos desde a leitura do desafio e apenas $M$ chegara a uma resposta. Aqui está mais um indício da devolução. Mesmo tendo ouvindo a resposta de $\mathrm{M}$, as demais alunas queriam chegar por seus próprios caminhos à resposta, importando esse caminho mais do que a resposta propriamente.

A aluna $\mathrm{K}$ também listou algumas possibilidades, mas D interveio apontando para a árvore de possibilidades que é a própria resolução de $\mathrm{K}$ para o desafio 1.

$\mathrm{D}-\mathrm{O}$ que é isso aqui?

Aluna $\mathrm{K}-\mathrm{A}$ casquinha.

$\mathrm{D}-\mathrm{E}$ isso aqui?

Aluna $\mathrm{K}-\mathrm{O}$ copinho. 
D- Ah, ta. Tenta usar isso no exercício2. Agora não é copinho nem casquinha.

Aluna $\mathrm{K}-\mathrm{E}$ o um. Vou fazer primeiro para um só. É que é muito diferente. D- Não é.

Aluna K. -É.

B- Chama o "um" de casquinha, o "três" de copinho...

Aluna K - "Tá" bom.

D- Olha no seu exercício, vê o que você fez.

A aluna $\mathrm{K}$ entendeu e começou traçar a árvore de possibilidades. Depois de um tempo, pedi que ela explicasse o que estava fazendo.

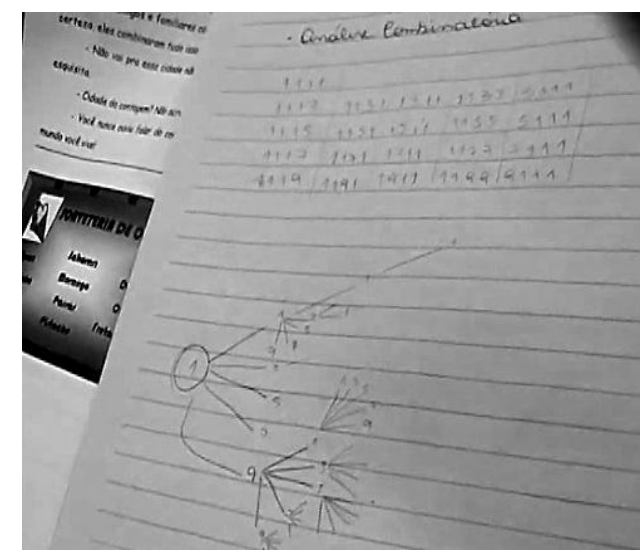

Figura 20- Outra resolução da aluna K para o desafio 2

Aluna K- São 25 possibilidades para um número inicial e o resto. Aí dá 25 vezes 5 para os que começarem com 1 . Dá 125 vezes 5 , que dá... 725?

W- 125 vezes 5 dá 625 . Explica de novo.

Aluna K- O início pra um primeiro número tem 25 possibilidades. Como são 5 números possíveis, então tem que fazer 25 vezes 5 . Então, você tem que fazer... perdi a explicação.

W- Mas você está convicta de que é isso? Ou tem dúvida ainda?

Aluna K- Ah, vai saber, né? Olha: Essa parte aqui vai se repetir 5 vezes. (E circula uma parte da árvore.)

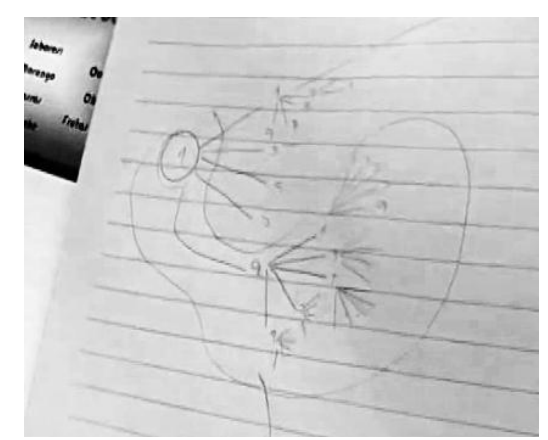

Figura 21- Outra resolução da aluna K para o desafio 2 (continuação) 
W- E o que é essa parte?

Aluna K-É os que começam com 1.

W- Com 1 e 9, né?

Aluna K- Isso, isso, isso, os que estão começando com 1 e 9. Aí eu vou fazer os que começam com 1 e 3; 1 e 5; 1 e 7. Aí vai dar tudo 25, 25, 25.

Aluna K- "25". Aí aqui vai dar isso. E aí vai ter que multiplicar por 5 para cada variação que haja no primeiro número... É isso?

W- Não sei, você que tem que saber (risos).

Ficou claro aqui que $\mathrm{K}$ estava experimentando a fase de formulação, assim como o aluno M. Ela descobriu o princípio multiplicativo sem que ninguém lhe dissesse nada a respeito. Já havia se passado 27 minutos desde a leitura e apenas dois alunos tinham chegado a uma conclusão, mas mesmo assim eles prosseguiram pensando sobre o problema, parecendo buscar uma generalização.

Aluno $\mathrm{M}$-Aí a cada um desse que muda aqui, tem outros 5 disponíveis. E a cada desse aqui que muda a gente tem outros 5 , disponíveis. Aí se a gente fosse usar isso aqui (aponta para o desafio 1), a gente teria isso aqui, certo? Que dá 6. Porque para cada um desses tem 3. Então o que eu percebi é assim se você pegar esse aqui e multiplicar por esse aqui é 3 vezes 2 que é 6 , vezes 2 que é 12. A gente tem 3 sabores. Agora tem que multiplicar 5 vezes 5 vezes 5 vezes 5 .

$\mathrm{I}-\mathrm{E}$ vai dar...

Aluno M-É muito.

W- E esse jeito que você fez tem alguma coisa a ver com o outro jeito que você tinha feito ou não? É a mesma coisa?

Aluno M - Sim, só que aquele é um pouquinho mais complicado de fazer. Porque eu estava olhando cada sequência em si. Quando você só olha para o número de alternativas possíveis, fica mais fácil.

W- Mas deu o mesmo resultado?

Aluno M- É, esse aqui foi mais chute de cego mesmo, eu percebi alguma coisa aí eu falei em voz alta, mas...

$\mathrm{W}$ - Mas deu o mesmo resultado?

Aluno M- Sim.

Parece que $M$ estava mais preocupado com a formulação e a validação de sua estratégia do que com a resposta do desafio em si e, por isso, ao ser perguntado sobre o resultado da multiplicação, respondeu apenas "É muito".

A aluna $\mathbf{J}$ também explicou seu raciocínio.

Aluna J- Aqui parece um arbusto. Eu me baseei nisso aqui, a sorveteria de Contagem. Eu peguei um tipo que seria número, depois eu peguei os sabores que seriam os 5 números, aí depois eu peguei as coberturas que seriam mais os 5 números. Só que tem 4 dígitos, então eu fiz mais uma fileira para dar os 4 dígitos. Aí vai dar... agora eu tenho que fazer a contagem. 


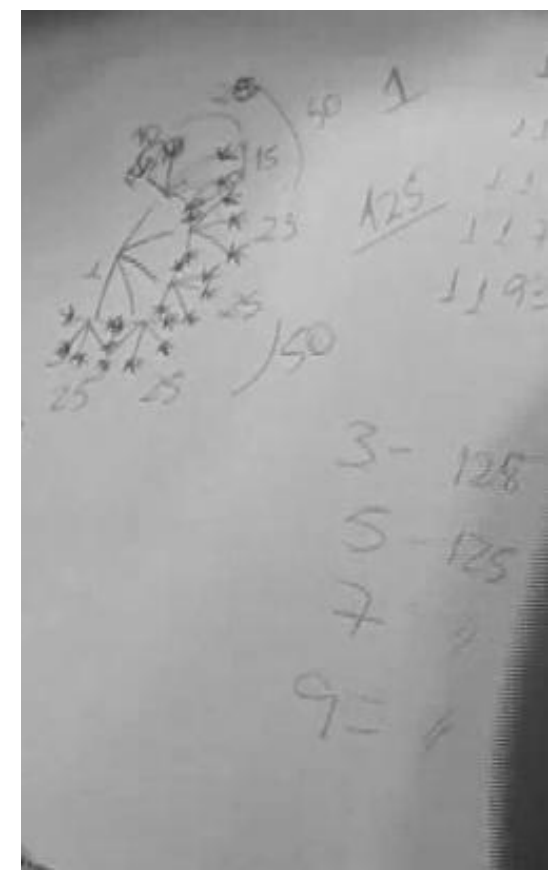

Figura 22- Resolução da aluna J para o desafio 2

A aluna $\mathbf{J}$ se apoiou na dica dos bolsistas (utilizar a mesmo método do desafio 1) para elaborar sua explicação. Como afirma Brousseau (1996, p. 59), "ao mesmo tempo que ensina um saber o professor recomenda como usá-lo. Manifesta-se assim uma posição epistemológica que o aluno adota muito mais rapidamente porque a mensagem permanece implícita ou ainda inconsciente, ${ }^{, 22}$.

B- Conta por arvorezinha.

Aluna J- É isso que eu vou fazer! $10+15=25$.

W- O que é esse 25 ?

Aluna J-É os que começam com 1.

B- Mas tem as outras.

Aluna J- Calma! 25+25+25+25+25

B- então, o que você pode falar disso?

Aluna J- Começando com o número 1 a gente teve $50+50+25=125$. Então para o número 3 também seria 125, para o número 5, 125. Para o 7 e o 9 também. $250+250+125=625$

\footnotetext{
${ }^{22}$ PAIS (2002, p.34) mostra como o modo de compreender um conceito é influenciado pelo modo de explicar e pela própria subjetividade presente na epistemologia do professor. Epistemologia do professor refere-se a "concepções referentes à disciplina com que trabalha esse professor, oriundas do plano estrito de sua compreensão que conduzem uma parte essencial de sua postura pedagógica.”
} 
Note que a operação utilizada por esta aluna foi a adição e não a multiplicação. Com certeza, a aluna sabe que 5 vezes 125 é o mesmo que $125+125+125+125+125$, mas diferente da aluna K, a multiplicação não surgiu naturalmente, então ela utiliza a adição e sua propriedade associativa. Essa sutileza na diferença entre os raciocínios nos revela um possível obstáculo para o entendimento do princípio multiplicativo e reforça a ideia de que o aluno precisa chegar a esse princípio por seu próprio raciocínio, do contrário não entenderá o porquê da multiplicação.

A mesma sutileza existe para a operação de potenciação. Nenhum dos alunos deu como solução do problema $5^{4}$, apesar de saberem que é o mesmo que $5 \times 5 \times 5 \times 5$. A ideia de potenciação não surge naturalmente na resolução dos problemas. Portanto, mostrar ao aluno essa resolução utilizando potenciação, antes que ele chegue à estratégia de solução por seu próprio esforço pode gerar um obstáculo didático ${ }^{23}$.

Apesar de não ter chegado ao princípio multiplicativo, não podemos dizer que $\mathbf{J}$ não estava experimentando as fases de formulação e validação.

Solicitei à $\mathrm{K}$ que fosse a lousa colocar sua resolução, ela sintetizou na lousa o que tinha feito em seu caderno. Na lousa a multiplicação apareceu apenas em $125 \times 5$. Mas ao explicar o que tinha feito no caderno, $\mathrm{K}$ fizera $25 \times 5 \times 5$. Em nenhum momento explicitou também o 25 como produto de 5 e 5 .

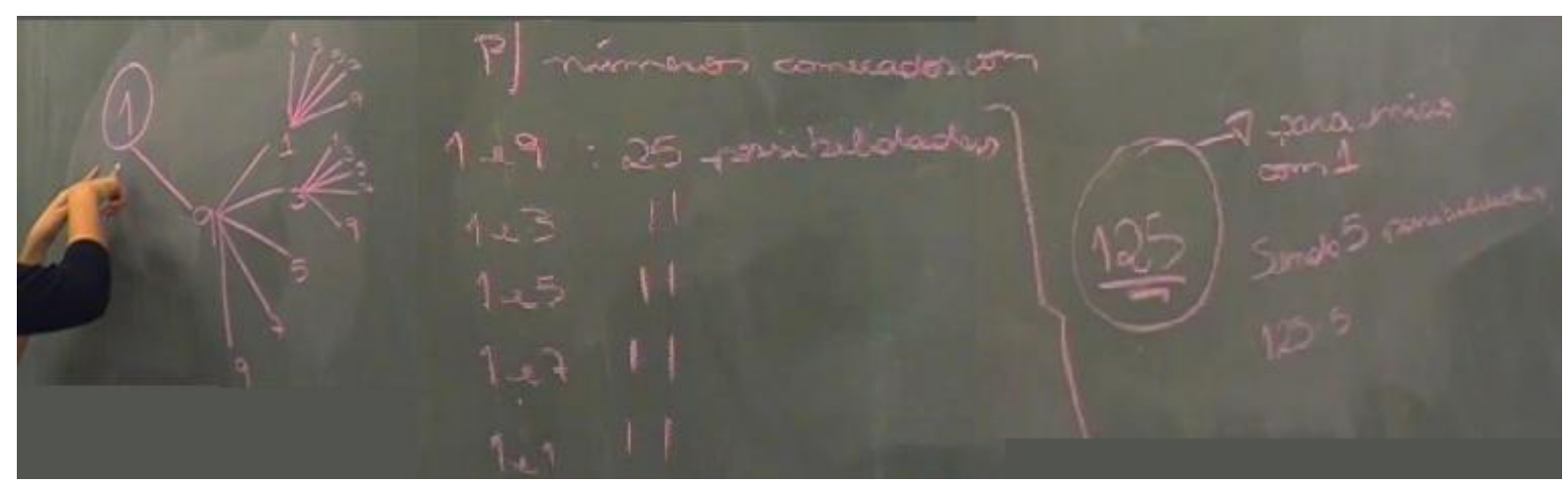

Figura 23- Resolução da aluna K para o desafio 2 na lousa

\footnotetext{
${ }^{23}$ Dentro da Didática da Matemática, Brousseau define quatro tipos de obstáculos: epistemológicos, didáticos, psicológicos e ontogenéticos. Apesar de não nos determos em mais este conceito no decorrer do trabalho, vemos que ele perpassa os três momentos do projeto, estando presente em cada dificuldade e incerteza dos alunos.
} 
A bolsista $\mathrm{B}$ foi à lousa com $\mathrm{J}$ para comparar a sua resposta com a resposta dada por $\mathrm{K}$, querendo que ela compreendesse o princípio multiplicativo, pois $\mathrm{K}$, ao término de sua resolução escrevera $125 \times 5$.

B-... Agora ela pegou e multiplicou esse 125 por 5. Só que lembra que você falou que fazia para o número 1 e depois somava os outros? Então: por que você soma e ela multiplicou?

Aluna J- Ela multiplicou porque ela já foi direto no ponto que é 125 .

B- Mas você também chegou ao 125 .

Aluna $\mathbf{J}$ - É que ela quis multiplicar e eu quis somar, porque dá a mesma coisa.

B- Dá a mesma coisa? Explica!

Aluna J- (Escreve na lousa) Tinha um número. Para esse número, tinha 125 possibilidades. Para o 3 seria a mesma coisa, para o 5, o 7 e o 9. Aí eu peguei $250+250+125=625$.

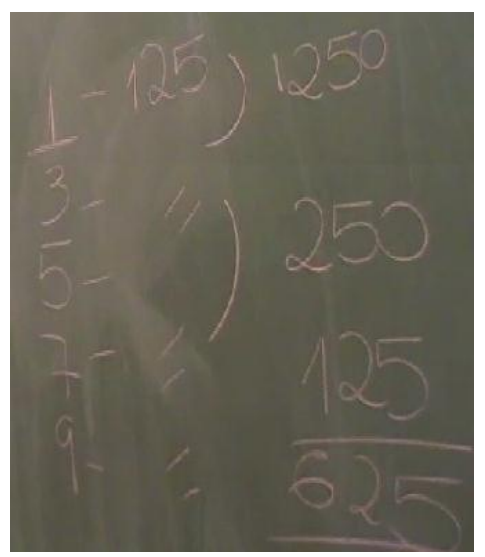

Figura 24- Resolução da aluna J para o desafio 2 na lousa

\section{Desafio 3}

$\mathrm{O}$ aluno M leu o desafio 3. Quando leu os anagramas da palavra CONTAGEM, suas colegas riram e disseram "Que menina chata!” “Aff!” "Que Marcela chata!” "Eu vou mandar essa Marcela para o mundo da Contagem". "Eu já não gostava desse nome." Ao término da leitura os alunos se uniram naturalmente em duplas: J e K; L e M. Então solicitei que fizessem alguns exemplos com as letras de emborrachado primeiro.

A dupla $\mathrm{J}$ e $\mathrm{K}$, tendo em mente usar a árvore de possibilidades se atrapalhou com o uso de letras, pois tentou com elas montar a árvore de possibilidades. Isolaram a letra $\mathrm{C}$ e colocaram as outras letras como possibilidades de ramos para ela. Chegaram a 7 vezes 7 . Depois multiplicam por mais um 7. E começaram a pedir por dicas: "É menos ou mais?"

$\mathrm{O}$ aluno $\mathrm{M}$, em menos de dois minutos, chegou a uma conclusão. 


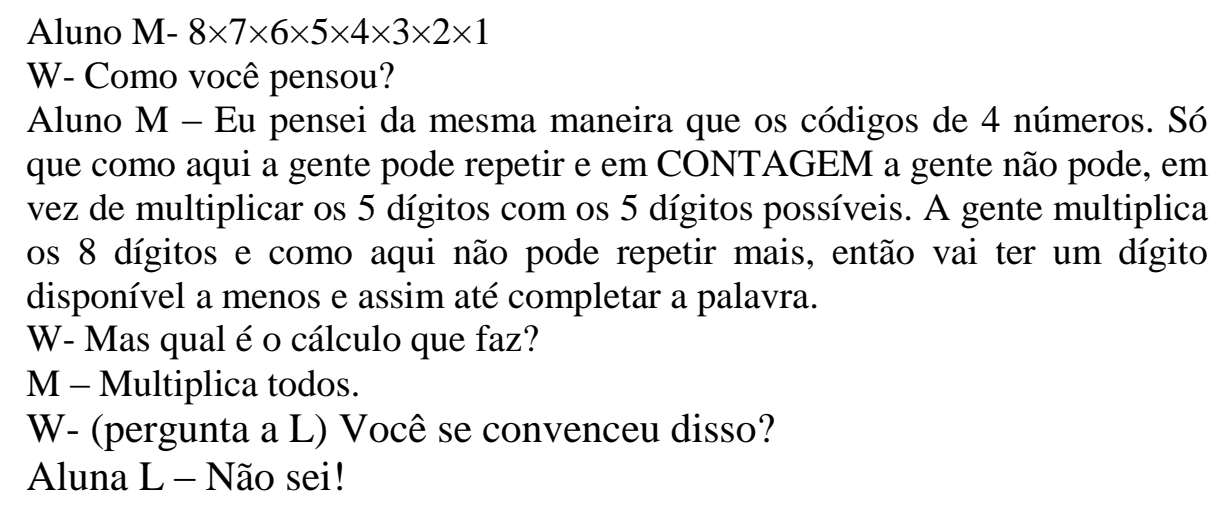

Através da árvore de possibilidades, $\mathrm{M}$ chegou rapidamente à resposta e naturalmente à pergunta “E se tivessem letras repetidas?”. Os bolsistas começaram então estudar, junto a ele os anagramas da palavra ANA e, depois, de BBBO.

Enquanto isso L continuava insegura em desenvolver um raciocínio, pois devido àquela primeira interrupção em seu raciocínio, não pareceu desenvolver nenhuma formulação. Ela continuou por um tempo assistindo $\mathrm{M}$ no que fazia, então a bolsista B sugeriu que ela se unisse a $\mathbf{J}$ e $\mathrm{K}$, as quais estavam ainda confundindo o uso das letras concretas com o uso da árvore de possibilidades. A aluna K, que queria utilizar as letras de emborrachado para montar a árvore de possibilidades, desabafou: “essas letrinhas não servem de nada- de nada!”

B explicou que ao multiplicar 3 números, as alunas estão considerando palavras de apenas 3 letras.

B- Olha, você tem o C, você fixou o C. Aí você fez 7 possibilidades para esse aqui.

Aluna J- Ah, já foi o "O".

B- Aí sobrou o quê?

Aluna J-6.

D- E depois?

Aluna J- Aí vem 5.

D E depois?

Aluna J- Aí vem 4. (risos) É muita pressão... 3, 2, 1. Então vai fazer vezes 7 vezes 6 vezes $5 .$.

A partir dessa fala, 50 minutos após o início da atividade, percebe-se que os bolsistas passaram a atuar de maneira diferente da que maneira como vinham atuando até então, intensificando gradualmente a quantidade de dicas. Parece que é natural, depois de certo tempo, perder a paciência por esperar o raciocínio emergir do aluno. 


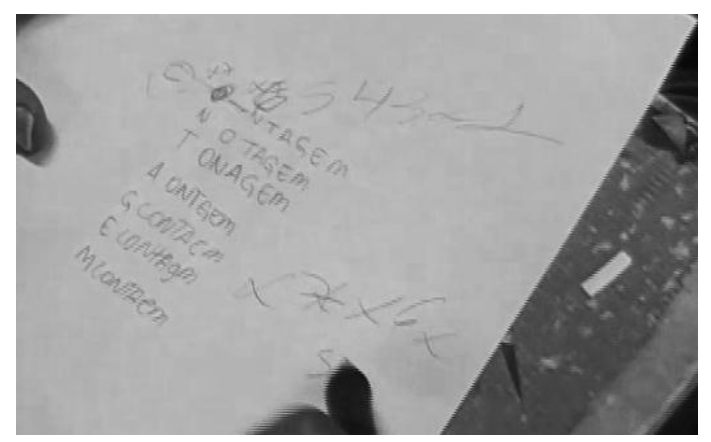

Figura 25- Resolução da aluna J para o desafio 3

B- O que vezes 7?

Aluna K- 7.

B- 7 vezes 7 ?

Aluna K. - Isso, que é o número de letras exceto o que é a primeira.

$\mathrm{W}$ - Mas qual o número de letras da palavra?

B- É que ela colocou um vezes aqui do além. Entendeu? Tinha que ter um número antes. Que número é esse?

Aluna J- É um.

D- Começados com C?

Aluna J- Começados com C.

Aluna K- 7 letras... 8 letras, 8 letras, gente. 8 vezes 7 vezes 6 vezes...

Aluna $\mathrm{J}$ - Mas aí já não conta porque é o $\mathrm{C}$ aqui.

B- Sim, mas lembra daquele seu papo de somar todas as possibilidades? Lembra que somar era a mesma coisa que ela fez de multiplicar pelo tanto de possibilidades.

Aluna J- Só que somar agora seria muito difícil.

B- Só porque tem 3 coisas a mais? Soma aí.

Aluna J-Somar o que, gente?

$\mathrm{B}-\mathrm{O}$ que você quer somar.

Aluna J- 1 mais 7?

B- Não.

Aluna J- Por que você está falando de somar? Você está me assustando.

Para, para!!!

A essa altura, $\mathbf{J}$ parece ter percebido uma mudança na postura da bolsista. B estava tentando direcionar o raciocínio de $\mathrm{J}$, mais do que antes.

Passado algum tempo, $\mathrm{J}$ e $\mathrm{K}$ entenderam que a quantidade de anagramas iniciados com a letra $C$ era o resultado da multiplicação $7 \times 6 \times 5 \times 4 \times 3 \times 2 \times 1$, mas não conseguiam perceber a necessidade de multiplicar esse resultado por 8. Então, a bolsista B pegou as letras de emborrachado e montou uma palavra começada com $\mathrm{O}$.

B- Só que tem essa palavra aqui que não começa com C. Você está contando as que começam com $\mathrm{C}$, certo? 
Aluna K- Então, por isso que eu falei que tem que ser vezes 7 . Uma já foi que começa com C, já foi!! Tem que ser $7 \times 6 \times 5 \times 4 \times 3 \times 2 \times 1$.

W- Começados com C.

Aluna K. Sim... Pára com isso!

(Aluna J pega uma calculadora e resolve $7 \times 6 \times 5 \times 4 \times 3 \times 2 \times 1$. Dá 5.040.)

Aluna J- É vezes 7, vezes 8... Para cada letra eu tenho 5.040 (...) Então aqui dá isso, que eu posso somar, ou multiplicar por 8 .

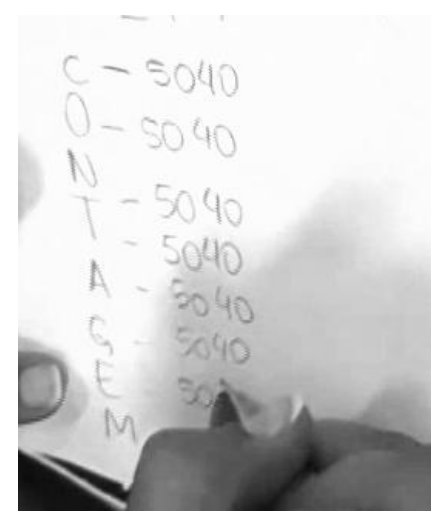

Figura 26- Resolução da aluna J para o desafio 3 (continuação)

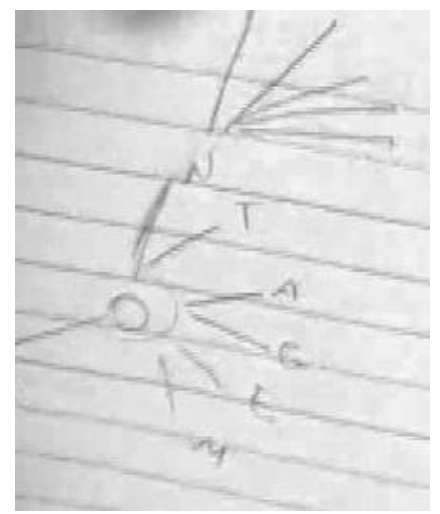

Figura 27- Resolução da aluna K para o desafio 3

$\mathrm{K}$ resolveu fazer sua própria árvore de possibilidades.

Aluna K- Então eu fixo C-O e para o C-O vai ter 6. Então aqui já foi $8 \times 7$ do começo. Aí pro C-O vão ter 6 possibilidades. Aì pro C-O-N vão ter 5 . Para o C-O-N-T vão ter 4. C-O-N-T-A vão ter 3. Vezes 2 vezes 1 . Esse é o resultado?

B- Isso.

Aluna K- Deixa eu ver quanto é que dá 40.320. Essa Marcela está me gastando, hein?!

Parece que J e K chegaram a uma solução para o desafio, mas L continuou insatisfeita e tentou então desenvolver seu próprio raciocínio, agora não mais fazendo uma lista de 
possibilidades, mas arriscando fazer uma árvore. Ficou um tempo olhando para o seu esquema e fez a contra devolução ao dizer que não conseguia mais avançar. Então, sugeri que a aluna escrevesse a palavra CONTAGEM com as letras de emborrachado.

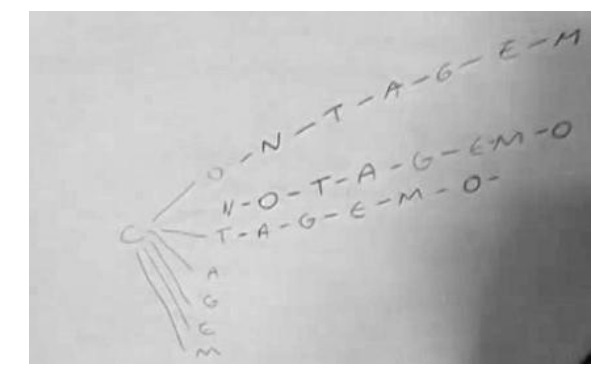

Figura 28- Resolução da aluna L para o desafio 3

W- Escreve CONTAGEM aqui pra mim. Mantendo as outras letras e trocando só as 2 últimas, quantos jeitos tem de fazer isso?

Aluna L- (troca as letras de lugar) dois.

W- Marca aí: dois. Só para as duas últimas, certo? E se você trocar as três quantos jeitos tem?

Aluna L- Seria 6 ?

W- Por que 6 ?

Aluna L- Eu não sei.

W- Pensa um pouquinho. Está certo, é 6. Mas por quê? (...) $\mathrm{Na}$ antepenúltima posição podem ser quais letras? Você está mexendo só nas três últimas.

Aluna L- Pode ser G, E ou M.

W- E pra cada opção tem duas.

Aluna L- Sim, então é 3 vezes 2.

W- Marca aí. E se você for trocar as 4 últimas? Que letras poderiam ser aqui? Marca a conta, não marca o resultado.

Aluna $L-4$ vezes 3 vezes 2 vezes 1 .

W- E se fosse 5? (e assim foi feito sucessivamente)

Podemos notar aqui que as letras de emborrachado foram mais úteis para a aluna $\mathrm{L}$ que ainda estava na fase de ação. Para K e L que já haviam experimentado a fase de formulação, as letras não ajudaram, pois queriam utilizá-las para montar uma árvore de possibilidades. Enquanto isso, o aluno $M$ tentava ainda "formular" a solução para a permutação com repetições. Por fim, chegamos ao quarto e último desafio e os alunos estavam animados pelas descobertas que vinham fazendo.

W- Vamos fazer o último desafio, gente? Só para encerrar?

Aluna K- Mas tem mais...

W- Não vai dar tempo, os outros vocês fazem em casa. 


\section{$\underline{\text { Desafio } 4}$}

O desafio 4 é continuação do 2. Nele, Marcela se lembra que a senha de quatro dígitos ímpares não tem 1 nem 9 e que o dígito 3 é o único que se repete. Como já era esperado e aconteceu nos demais momentos, foi difícil perceber que esse desafio se tratava de uma permutação com repetição.

Por ser continuação do desafio 2, pensa-se logo em subtrair algumas das possibilidades das 625 que resultaram do segundo desafio. Mas essa alternativa seria muito mais trabalhosa que contar novamente as possibilidades que agora restam-12, através do princípio multiplicativo ou mesmo voltando para a fase de ação e encontrando todas as possibilidades com uma lista. Para isso, os alunos precisariam perceber que se tratava de uma permutação como a das letras $\mathrm{C}, \mathrm{O}, \mathrm{N}, \mathrm{T}, \mathrm{A}, \mathrm{G}, \mathrm{E}$ e M só que agora com uma repetição. Para perceber a permutação, os números de emborrachado poderiam ajudar, pois os alunos perceberiam que qualquer uma das senhas estariam sendo formadas com os mesmos 4 dígitos.

Assim que $\mathrm{K}$ leu o quarto desafio, todos começaram a rir.

Aluna J- "Péra" aí, "pêra" aí. A gente pega o que a gente já fez, tira todas as possibilidades do 1 .

Aluna K- Já tira 125.

Aluna J- E nem 9...

Aluna K - Já tira mais 125 .

W- Não, são 125 que começam com 1 , mas não pode ter 1 nem no meio.

(K coloca a mão na cabeça).

Aluno M- Então é o meu método. Em cada espacinho de número vai ter um a menos.

Na situação transcrita acima, J e K queriam imediatamente utilizar o desafio 2, mas M percebeu em seguida que se tratava de uma permutação como a do desafio anterior.

D- Essa é uma senha, faz outra senha.

Aluno M- Eu não vou fazer todas.

D- Mas não é pra fazer. É pra você entender.

Aluno M- É 3 vezes 3 vezes 2 vezes 1 ?

(...)

D- Você já sabe que dois três se repetem, não sabe? O que eu te expliquei?

Aluno M- ...

(...)

D- O 3 se repete, vai ter 2 vezes o número 3. 
No trecho acima, D fez referência ao cálculo do número de anagramas das palavras ANA e BBBO que vinham fazendo. O bolsista queria que o aluno percebesse que se trata de uma permutação com repetição como as outras. Primeiro tentou fazer que o aluno escrevesse duas permutações possíveis para que percebesse isso, mas o aluno se negou a iniciar uma lista.

Quando os alunos vivenciam a fase de formulação em um desafio, parece que no desafio seguinte é mais difícil retomar a fase de ação. Acreditamos que isso pode ocorrer, em alguns casos, devido a uma cláusula implícita do Contrato Didático de que resolvendo o primeiro exercício de uma lista, os demais devem seguir a mesma lógica.

Enquanto isso J e K se perdiam em seus raciocínios. Ambas queriam multiplicar 4 por alguma coisa, pois consideravam que para primeiro dígito haviam 4 opções (7, 5, 3 e o outro 3). J fez 4 vezes 27 e K, 4 vezes 18. J chegou a fazer uma árvore de possibilidades, por sugestão do bolsista $\mathrm{D}$, mas não conseguia chegar a uma conclusão.

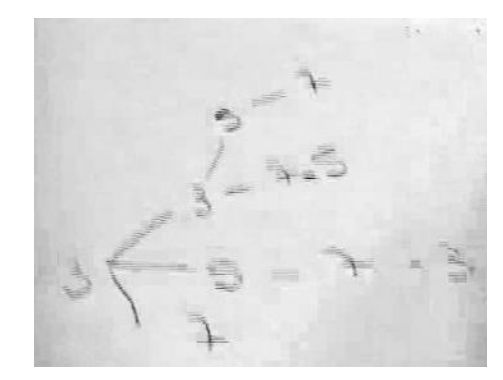

Figura 29- Resolução da aluna J para o desafio 4

Por fim, K percebeu seu erro e resolveu a permutação de 4 elementos sem levar em consideração que um deles se repete.

Aluna K- 24 possibilidades (...) São 6 possibilidades para cada começo.
Aluna J- 6 vezes 6 vezes 6 ?
B- Por que 6 ? Da onde você tirou 6 ?
Aluna K- Das possibilidades, mas eu acho que não é multiplicação, é soma!
Aqui é 6 possibilidades para começo com 3 mais 6 possibilidades para
começo com 5 , mas 6 possibilidades para começo com 7 , mais 6 para
começo com... não.

A aluna $\mathrm{K}$ resolveu esse desafio exatamente como o anterior, sem levar em consideração que o 3 se repete. Desse modo, percebeu que deveria fazer $4 \times 6$. J compreende o 6 , mas esquece o sentido de somá-lo 4 vezes e vai logo querendo multiplicar o 6 pelo próprio 
6, mas $\mathrm{K}$, que desenvolveu o raciocínio explicou, dando ênfase à palavra "mais"- "6 possibilidades para começo com 3 mais 6 possibilidades para começo com 5, mais 6 possibilidades para começo com 7”. E então ela interrompe sua frase, pois percebeu que desconsiderou a repetição, pois contou duas vezes senhas iniciadas por 3.

J deu uma solução: bastaria somar o 6 por três vezes em vez de quatro. Então a bolsista $\mathrm{B}$ interveio, utilizando os números concretos, deixando um 3 de cada cor e mostrando que não há diferença quando trocados de lugar.

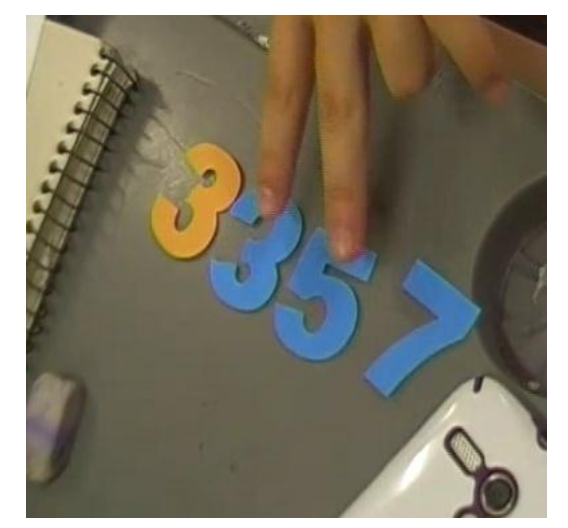

Figura 30- Dica com números concretos para o desafio 4

Ninguém disse a $\mathrm{K}$ que seu raciocínio estava correto e que bastava continuar, descontando as senhas repetidas. Já que ela contou duas vezes cada senha, bastaria agora dividir 24 por 2. Então, $\mathrm{K}$ começou a ficar muito frustrada e se debruçou sobre a mesa mostrando desinteresse. Acredito que seja porque ela estava convencida de seu raciocínio e de que a resposta fosse 24 e ninguém validou sua resposta, incentivando que continuasse.

Ao perceber a frustração de $\mathrm{K}$ e a dificuldade que estavam tendo para chegar à resposta, a bolsista B resolveu ela mesma pegar o lápis e fazer a lista de possibilidades.

B- Primeiro eu fixei 3-3, depois 3-5 e depois 3-7, "ta"? Daí o que eu fiz? Sobrou o 5 e o 7. Eu fiz todas as permutações que eu consegui. Daí eu coloquei o 5 pra frente. Fixei 5-3. Daí deu 3-7, 7-3. Agora fixei 5-7. Fica 77-3-3. Agora se eu trocar o 3-3 de lugar, eu vou estar contando a mais. Porque 33 é igual a 33. Por isso que deu menos.

A contra devolução foi feita não por parte dos alunos, mas por parte da própria bolsista, que tomou de volta para si a responsabilidade pela resolução do desafio. 
Enquanto isso o aluno $\mathrm{M}$ já tinha resolvido o desafio dividindo 24 por 2. Já resolvera os anagramas de ANA dividindo 6 por 2. Mas ainda não tinha entendido qual a regra para se resolver casos de permutação com repetição, já que eram 4 os anagramas de BBBO e 24 se não houvesse repetições.

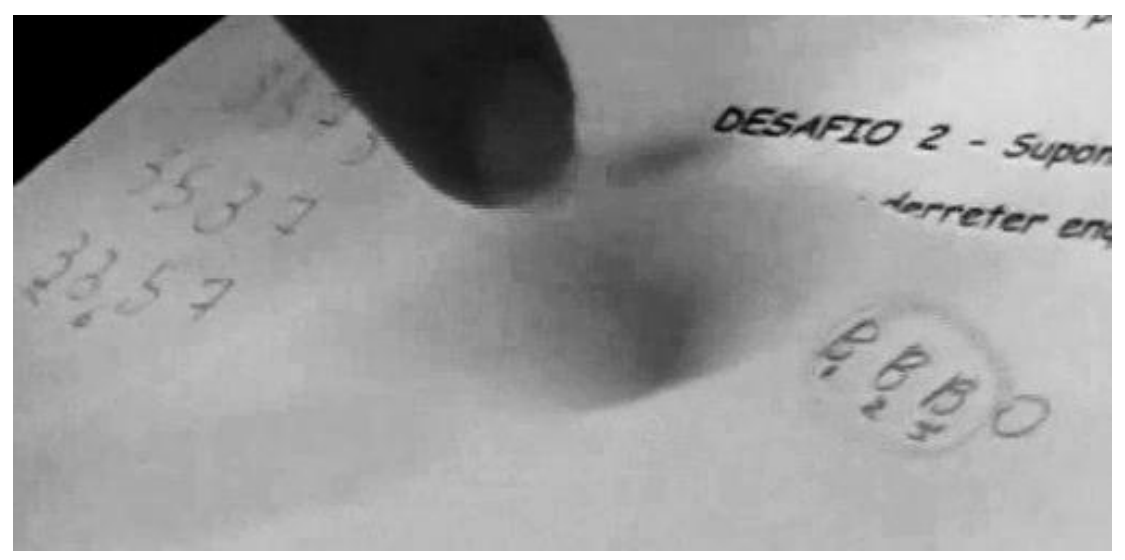

Figura 31- Resolução do aluno M para o desafio 4

Aluno $\mathrm{M}-\mathrm{B}_{1}, \mathrm{~B}_{2}, \mathrm{~B}_{3}$ é a mesma coisa que $\mathrm{B}_{3}, \mathrm{~B}_{2}, \mathrm{~B}_{1}$. $\mathrm{H}$ - Se você tivesse uma palavra só com esses três B's... Aluno M- Já sei, divide por 3 !

(Depois de mais dicas de $\mathrm{H}, \mathrm{M}$ chega à conclusão de que há 6 permutações dos três B's).

H- Isso, então você tem que tirar essa troca porque essa troca não existe. Então você faz o que com aquele 24? Aqui você dividiu por 2 porque era troca de dois. Aqui é troca de três e a troca de três você acabou de me falar.

Aluno M- Três?

H- Não, qual é a troca?Você acabou de me falar.

Aluno M- 3 vezes 2 vezes 1 .

H- Então o que você faz com o 24 ?

W- Quantas vezes você está contando a mesma coisa?

H- Você acabou de falar quanto dá a troca em três. Você quer tirar essa troca em três.

Aluno M- Dá 3 vezes 2 vezes 1.

H- Então o que você faz?

Aluno M- Divide por 6? Dá 4.

W- É dá 4 mesmo, porque ou o "O" está aqui, ou aqui, ou aqui, ou aqui.

Aluno M- É o que você fez aqui.

Aluno M- Mas não tem um padrão? E se forem 4 por exemplo?

H- Faz aí. 


\section{$\underline{\text { Rumo a uma institucionalização do saber }}$}

Nesse terceiro momento de aplicação do projeto a formalização foi feita não ao término de cada desafio, mas após os quatro desafios. Por ter sido breve, percebemos que os alunos ficaram insatisfeitos querendo entender mais sobre o assunto e querendo também resolver mais desafios.

Houve, nessa fase, apenas uma exposição oral feita por uma das bolsistas com alguns registros na lousa sobre a resolução dos desafios. Nenhum texto foi dado com a formalização do assunto, o que foi cobrado posteriormente pelos alunos, segundo relato dos bolsistas no questionário final: "Uma das meninas pediu que nós "amarrássemos" o conteúdo, ou seja, déssemos uma devolutiva e um resumo sobre o tema estudado. Outra estudante não gostou quando o tempo se esgotou, dizendo que queria fazer mais exercícios”.

Ao término da aplicação da Sequência Didática, quando faltavam 10 minutos para encerrar o tempo previsto para a aplicação do projeto, pedi que um dos bolsistas fosse a lousa desenvolver essa etapa de formalização. H se propôs a ir e escreveu:

\section{PRINCÍPIO MULTIPLICATIVO}

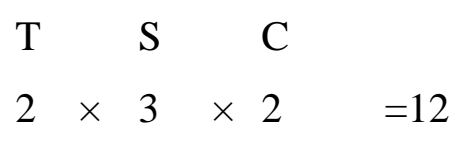

Logo abaixo, para explicar o segundo desafio, H coloca 4 traços na lousa, explicando: "Você vai ter 4 dígitos. E como pode repetir você vai ter 5 possibilidades de primeiro, 5 possibilidades. Aí para o segundo você vai ter mais 5 possibilidades (gesticula como se fizesse uma árvore de possibilidades). Para cada um aqui você vai ter mais 5 e para cada um aqui mais 5 . O total vai ser 5 vezes 5 vezes 5 vezes 5 que é igual a $5^{4}$ ".

$$
\underline{5} \times \underline{5} \times \underline{5} \times \underline{5}=5^{4}
$$

Depois, H apaga a lousa e diz "O outro desafio é de anagramas. O Josenilton falou ontem que permutação é troca. Quando se fala de anagramas, se fala da troca entre as letras de uma palavra. Permutação. (Coloca um P na lousa) São oito letras (coloca 8 no índice) e como não tem letra repetida, você não coloca nada em cima. Isso é igual ao fatorial de 8”. 
$\mathrm{P}_{8}=8$ !

Os alunos estranham o símbolo de fatorial e $\mathrm{H}$ explica "Oito fatorial é aquilo que vocês fizeram (coloca 8 traços na lousa e sobre eles os números 8, 7, 6, 5, 4, 3, 2, 1 - depois os símbolos de vezes entre os números). O fatorial é para você não ter que escrever isso sempre".

W- Aí na calculadora em vez de fazer 8 vezes 7 vezes 6 vezes..., dá pra fazer 8 fatorial direto.

Aluna K- (resolve 8! na calculadora) Nossa! Que fácil!

Aluna J- (resolve 8! na calculadora) Não acredito!

Aluna K- Nossa! Não a gente ia ficar boiando na aula.

Para os alunos, a explicação sobre o fatorial parece ter sido uma informação valiosa, eles comentaram que ficaram contentes por saberem disso antes dos outros colegas do segundo ano. Em seguida, a aluna J perguntou se sempre faz assim. Então, eu respondi que apenas se tratando de permutação sem repetições e $\mathrm{H}$ mostrou as permutações da palavra ANA.

Aluna J- Então sempre que for esse com repetição aí, esqueci o nome.

W, B- Permutação com repetição.

Aluna J-O de cima depende da palavra e dividido por 2.

Aluna K- Depende do número de repetição.

Aluna J- Verdade. Depende do número de repetições.

$\mathrm{H}$ prossegue explicando com os anagramas de BBBO, mas o tempo acaba e alguns alunos precisam ir embora. Não foi feita a formalização do $4^{\circ}$ desafio, a não ser com exercícios semelhantes- permutação de ANA e BBBO.

\section{Questionário respondido pelos bolsistas}

Após a aplicação da Sequência Didática os três bolsistas que participaram da situação, responderam a um questionário (veja o anexo), pois gostaríamos de saber as suas percepções sobre a concretização ou não de devolução e de situação adidática, e sobre as contribuições trazidas por cada elemento do meio para que houvesse essa concretização. Os resultados da primeira questão (sobre os alunos) estão abaixo relacionados:

- Todos os bolsistas concordaram que os alunos sentiram a necessidade de resolver os desafios. 
- Apenas a bolsista $\mathrm{H}$ percebeu que, entre as estratégias adotadas pelos alunos para resolver os desafios, houve a estratégia de listar todas as possibilidades.

- Apenas o bolsista D acredita que a estratégia da árvore de possibilidades tenha surgido independentemente das dicas dadas pelos bolsistas.

- Apenas a bolsista $\mathrm{H}$ acredita que os alunos perceberam o princípio multiplicativo sozinhos, os demais responderam que o princípio multiplicativo foi percebido com a ajuda dos bolsistas.

- Em suas opiniões, a necessidade de generalização foi percebida pelos alunos com dicas dos bolsistas. De acordo com B, a percepção dessa necessidade foi totalmente direcionada pelos bolsistas.

- Apenas a bolsista $\mathrm{H}$ acredita que, sozinhos, os alunos sentiram a necessidade de conhecer as fórmulas, os demais acreditam que a percepção dessa necessidade foi totalmente direcionada pelos bolsistas.

Pela diversidade de situações vivenciadas durante a aplicação do projeto e pela própria diversidade de alunos presentes, houve diferença nas respostas dos bolsistas. O que se pode observar de comum entre as respostas é que todas elas apontam para a existência das etapas de devolução, ação, formulação e validação.

Desse modo, podemos avaliar que houve uma situação adidática na opinião dos bolsistas. O que varia é a percepção dos bolsistas sobre a autonomia dos alunos para o surgimento de cada uma dessas etapas e influência que exerceram para que essas etapas ocorressem.

Para a questão 2 (sobre os recursos utilizados) as respostas foram, na média, as seguintes:

- A narrativa contribuiu razoavelmente para que houvesse devolução, razoavelmente para que houvesse aprendizagem e razoavelmente para que houvesse uma situação adidática.

- A árvore de possibilidades contribuiu razoavelmente para que houvesse devolução, muito para que houvesse aprendizagem e razoavelmente para que houvesse uma situação adidática. 
- A palavra desafio em vez de exercício contribuiu razoavelmente para que houvesse devolução, pouco para que houvesse aprendizagem e pouco para que houvesse uma situação adidática.

- A presença dos bolsistas contribuiu muito para que houvesse devolução, razoavelmente para que houvesse aprendizagem e pouco para que houvesse uma situação adidática.

- O fato de Análise Combinatória ser o próximo conteúdo da escola contribuiu muito para que houvesse devolução, razoavelmente para que houvesse aprendizagem e pouco para que houvesse uma situação adidática.

- Sobre as letras e números de emborrachado houve grande divergência de opiniões. Enquanto para B, esses objetos contribuíram muito para que houvesse devolução, muito para que houvesse aprendizagem e muito para que houvesse uma situação adidática. Para os outros dois bolsistas, os objetos contribuíram pouco.

Nessa questão, os bolsistas associam a devolução principalmente à própria presença deles em sala de aula e ao fato de Análise Combinatória ser o próximo conteúdo escolar de Matemática; acreditam que houve aprendizagem principalmente devido ao esquema de árvore de possibilidades; e divergem em suas respostas sobre a relação desses fatores com o surgimento da situação adidática- B acredita que as letras e números concretos tenham contribuído fortemente para que ocorresse a situação adidática e $\mathrm{H}$ acredita que a árvore de possibilidades tenha contribuído para tal.

Vejamos agora as respostas dos bolsistas sobre suas próprias posturas na condução da situação:

- A bolsista B e o bolsista D notaram poucas vezes que estavam antecipando o raciocínio dos alunos e com frequência evitaram fazê-lo.

- A bolsista $\mathrm{H}$ notou com frequência que estava antecipando o raciocínio dos alunos e poucas vezes evitou fazê-lo.

Sobre a importância da fase de institucionalização, B e D não a consideraram importante, enquanto $\mathrm{H}$, que conduziu essa fase, a considerou muito importante. 
Nas observações, a bolsista B levantou uma questão muito pertinente. Segundo ela, por serem diferentes os tempos de aprendizado, a velocidade com que um aluno resolve o desafio, acaba desestimulando outros alunos.

Tentamos fazer com que os alunos resolvessem os desafios sozinhos. Porém cada um tem seu tempo, existindo alunos mais rápidos. Enquanto um aluno ainda não tinha concluído seu pensamento, outro foi falando em voz alta seus resultados. Isso pode influenciar no pensamento, desmotivar ou tirar a concentração do aluno que ainda não terminou. Devido a este fato, o aluno se perdeu e tive que voltar ao pensamento anterior e encaminhá-lo para o próximo, para que o raciocínio não se quebrasse. A insegurança e diferença na forma de resolução pode desmotivar um aluno. Não soube lidar com esta situação. (Resposta da bolsista B ao questionário final)

Ainda nas observações, a mesma bolsista achou importante acrescentar: "Os alunos tiveram uma aula anterior à aplicação do projeto com o Professor Josenilton, que explicou o princípio multiplicativo e a árvore de possibilidades. Assim acredito que o resultado da aplicação tenha sido um pouco alterado". Sobre a árvore de possibilidades, acreditamos que esta foi uma ferramenta que auxiliou, principalmente as alunas $\mathrm{J}$ e $\mathrm{K}$ a desenvolverem seus raciocínios. Os outros dois alunos nem mesmo se lembravam dela. Sobre o princípio multiplicativo, percebemos que a aula dada pelo professor Josenilton não foi suficiente para que eles desenvolvessem o vício de procurar no problema o que multiplicar, como vimos nos momentos anteriores de aplicação do projeto.

\subsubsection{Conclusões sobre o terceiro momento}

Ao transcrever os acontecimentos do $3^{\circ}$ momento do projeto eu me senti como se estivesse escrevendo um daqueles livros paradidáticos ${ }^{24}$, nos quais os personagens vão descobrindo com tanta naturalidade os conteúdos matemáticos. Sintetizando essa transcrição, seria perfeitamente possível escrever uma história como aquelas, com uma diferença: os personagens são reais. Ao pensar nisso, comecei a acreditar, mais do que antes, que é possível os alunos terem vontade de aprender e que a situação adidática não é uma utopia.

\footnotetext{
${ }^{24}$ Realizei meu projeto de Iniciação Científica analisando o uso de livros paradidáticos de Matemática na escola de aplicação. Trevizan, W. A - O uso do livro paradidático no ensino de Matemática, USP: 2008. Parcialmente disponível em http://www3.fe.usp.br/secoes/semana08/completos/59.swf
} 
Mostraremos a seguir que, neste terceiro momento, todas as fases da situação adidática foram percorridas, buscando evidenciar a importância que os bolsistas tiveram em cada etapa, bem como a importância dos recursos utilizados. Em seguida, mostrarei as contribuições deste terceiro momento para o presente trabalho e, inclusive, para trabalhos posteriores.

\section{$\underline{\text { As fases da situação adidática }}$}

1. Devolução: No decorrer dessa análise percebemos vários indícios de que houve uma devolução dos desafios maior que nos outros casos. Podemos citar, por exemplo, o cuidado na busca pela resposta. Por não estarem no espaço formal da escola, pressionados pelo tempo e pela obrigatoriedade de entregar uma resposta, ainda que incerta, que "vale nota"; nesse terceiro momento, os alunos não dão uma resposta descompromissada aos desafios e não repetem a resolução de outro colega, eles querem encontrar sua própria resposta, seu próprio entendimento.

Percebemos algumas etapas existentes dentro da própria devolução. São elas:

- A aceitação da proposta de resolver o desafio. Nesse caso, por não ser uma atividade obrigatória, essa aceitação por parte dos alunos presentes parecia já estar garantida, mas apareceram alguns obstáculos como a insegurança de L para prosseguir com suas resoluções, o desânimo de $\mathrm{K}$ diante da ausência do reconhecimento de sua estratégia e o desânimo de alguns alunos diante da rapidez com que outro colega tenha chegado à resposta, como destacou no questionário a bolsista B. Nesses casos, os bolsistas ou eu precisávamos intervir para que a situação prosseguisse.

- A compreensão do desafio. Essa etapa precisa ser vigiada, pois uma resolução equivocada às vezes procede de uma interpretação equivocada. Em vários momentos os bolsistas precisaram intervir para explicar o que estava sendo perguntado, principalmente no desafio 4. Nessa etapa de compreensão do desafio, as letras e os números de emborrachado também tiveram um papel importante.

- A necessidade real de resolver o desafio, que pode ter sido gerada pela narrativa e que, a princípio, é a curiosidade por saber sua resposta. Logo no início do desafio 2, a aluna $\mathrm{K}$ e $\mathrm{L}$ arriscaram palpites para a quantidade de possibilidades: 20, bilhares, infinitos, simplesmente por intuição. 
- A transferência da necessidade de saber a resposta para a necessidade de descobrir o procedimento (generalização) que leve à resposta em casos análogos. Essa transferência parece ter surgido naturalmente na situação analisada. Vimos que ao ser perguntado sobre o resultado do desafio 2, M disse apenas "muitos", como que estando interessado no modo de fazer e não na resposta numérica. Vimos também que ao colocar a resolução do desafio 2 na lousa, a aluna K não colocou a resposta, apenas a indicou como $125 \times 5$. Também durante a institucionalização, quando a bolsista $H$ falou sobre permutação simples e com repetição, J perguntava: É assim que faz sempre?

- O desejo de continuar aprendendo, que se revelou na satisfação dos alunos ao descobrirem cada resposta e na insatisfação quando o tempo para resolverem os desafios se esgotou.

Pudemos perceber que a devolução não ocorre somente no início de cada desafio, mas durante toda a situação adidática. Ela é responsável por desencadear as fases de ação, formulação, validação e pode gerar a necessidade da institucionalização. Ela interfere também no tempo longo do conhecimento, quando promove o desejo de continuar aprendendo.

2. Ação: Estando motivado em resolver o desafio, tendo o compreendido e sentido a necessidade real de resolvê-lo, o aluno parte em busca da resolução desse desafio, normalmente iniciando por essa fase de ação em que predomina a contagem direta, várias vezes apontadas na análise dos dados. O principal recurso utilizado para a contagem direta em casos em que o número de possibilidades é alto foi a árvore de possibilidades, a qual já é um grande passo rumo à formulação, pois nela é fácil perceber o princípio multiplicativo.

Nessa fase, notamos nos alunos algumas das dificuldades mencionadas por Batanero (apud PINHEIRO, 2008, p.21), entre elas: enumeração não sistemática, uso incorreto do diagrama de árvore, erro de repetição. Para identificar essas dificuldades e alertar os alunos, vimos como foi importante também a presença dos bolsistas

3. Formulação: Como mostrado na análise de dados, essa fase foi alcançada, diferentemente, pelos quatro alunos, os quais "descobriram" o princípio multiplicativo. A principal dificuldade nessa fase é que os alunos não usam termos formais, pois estão eles mesmos descobrindo o conhecimento. Sendo assim, ocorrem nas falas imprecisões, 
redundâncias, metáforas, ambiguidades. Como menciona Brousseau (1986), há uma adequação da linguagem para comunicar o novo conhecimento. Essa linguagem deve ser compreendida (e formalizada, no momento propício) pelo professor.

Como pudemos perceber, nem todos os alunos chegaram naturalmente à operação de multiplicação, muito menos à potenciação. Em vez da multiplicação, J pensou primeiramente na adição. Se não tivesse chegado, por si, ao raciocínio de somar 5 vezes o número 125, no desafio 2, a aluna $\mathbf{J}$ não teria compreendido o porquê do princípio multiplicativo.

4. Validação: É difícil separar formulação de validação no caso de Análise Combinatória, pois ao mesmo tempo em que busca uma generalização, o aluno sente a necessidade de explicar e verificar se seu raciocínio está correto. Um dos momentos da situação em que nitidamente essa fase ganha espaço próprio é quando o aluno $\mathrm{M}$ pede um tempo para "explicar a si mesmo" o seu raciocínio para o desafio 2. Ele já havia formulado a solução: 25 vezes 25 , e agora gostaria de se convencer do porquê desta solução.

5. Institucionalização: Apesar de não ter sido realizada de modo completo nas 2 horas em que os dados foram coletados, realizou-se posteriormente pelos próprios bolsistas e pelo professor Josenilton, que prosseguiu trabalhando com este tema.

\section{Limitações inerentes a uma sala de aula}

Por ser realizado no contra turno com apenas quatro alunos, esse terceiro momento do projeto foi profícuo em dois sentidos:

Primeiro, nos fez prestar mais atenção em fatores que também estão presentes em uma sala de aula, em escala ainda maior, mas que passam despercebidos pelo grande número de alunos ou pelo tempo limitado. Por exemplo, percebemos como as inseguranças e as diferenças podem ser obstáculos para a que a situação adidática prossiga, bem como a não valorização por parte do professor de um raciocínio correto do aluno. Percebemos também a tendência dos bolsistas de, com o passar do tempo, gradualmente intensificar o número de dicas, o que levou em alguns momentos os alunos a pedirem que parassem, pois já não estavam mais acompanhando o raciocínio.

E em segundo lugar, esse momento trouxe potencialidades que a sala de aula geralmente não tem, mas que poderia ter. Seria interessante se outros trabalhos, na continuidade deste, pudessem investigar a possibilidade de um Contrato Didático que levasse em consideração: 
- O respeito pelo tempo do aluno, para que ele possa passar pelas fases de ação, formulação e validação, de modo que o tempo esteja em função da Sequência Didática e não o contrário.

- A flexibilidade na forma de trabalho individual/ em grupo, baseada na percepção do professor e dos alunos sobre as necessidades que surgem.

- A atenção do professor para com cada aluno individualmente para que ele possa apresentar seu raciocínio e o professor possa perceber as lacunas e incoerências.

- O centro das situações posto na aprendizagem e não no simples "tirar nota".

- A variedade de Sequências Didáticas, de modo que o aluno não seja induzido a pensar que todos os dados necessários para a solução estão prontos no problema, ou que se resolvendo um problema de uma lista, os demais serão análogos. 


\section{Considerações finais}

Esse projeto de pesquisa caminhou paralelamente ao meu projeto profissional. Motivada pela pergunta-chave "É possível planejar situações potencialmente adidáticas?" percorri todas as etapas da pesquisa, enquanto iniciava em minha carreira profissional. Portanto, cada um dos três momentos explorados na pesquisa é, de certa forma, também uma metáfora de três momentos diferentes de minha atuação profissional - antes de assumir uma sala de aula; enquanto atuava na Educação Básica e, por fim, atuando na formação profissional (técnica e superior).

Durante esse percurso, participei, como aluna, de dois programas diferentes de pósgraduação, sendo o segundo, o Programa de Mestrado Profissional em Ensino de Matemática (MPEM) do IME-USP. Desde meu ingresso na Licenciatura, eu ouvia falar a respeito do projeto desse programa e, então, tive o privilégio de fazer parte de sua primeira turma, sendo a primeira aluna do programa a realizar a defesa da dissertação.

Participei também, como professora, de duas diferentes instituições de ensino, uma privada e outra pública, já mencionadas no decorrer do trabalho - o SESI e o IFSP. Participei, como pesquisadora, de dois momentos distintos da Escola de Aplicação, com dois professores distintos, os quais foram também meus supervisores de estágio durante a Licenciatura. Em cada um dos três momentos dessa pesquisa, utilizei métodos e recursos diferentes para registrar os dados.

Creio ter crescido muito. Essa diversidade de experiências me fez perceber que a vida é um laboratório de aprendizagens, basta apenas que nós estejamos em busca de responder uma questão e olhemos para cada acontecimento como uma peça do quebra-cabeça que estamos tentando montar.

Durante essa jornada de idas e vindas, de aprendizagens, de crescimento, entre a teoria e a prática, entre acertos e erros, conclui muito mais coisas do que pretendia responder com a pergunta-chave. Fui levada a concluir, por exemplo, que pesquisa e ensino de fato caminham juntos e que todo professor deveria ter uma questão em mente e persegui-la. Percebi que o bom professor não é necessariamente aquele que teve uma boa formação inicial, e nem aquele que tem muitos anos de experiência, mas aquele que vê a vida como um laboratório de aprendizagens. Sei que não fui a primeira a perceber isso, mas a grande satisfação reside no 
fato de ter aprendido essa lição, não apenas por ter lido em algum lugar, mas por ter vivenciado por mim mesma.

Isto é o que tentei propor o tempo todo com as situações adidáticas: que os alunos não aprendam apenas absorvendo as ideias que vêm de alguém, mas que aprendam experimentando, acertando, errando, tentando. Esse é o verdadeiro aprendizado: aquele que surge do próprio indivíduo aprendiz. Isso é situação adidática.

Durante muito tempo, eu buscava uma resposta objetiva para a pergunta-chave. "Sim, é possível elaborar situações potencialmente adidáticas". Ou: "Não, isso não é possível." Hoje percebo que o processo de ensino e aprendizagem é muito mais complexo do que imaginava no início desta pesquisa e que, portanto, a resposta não é tão objetiva assim.

As diversas variáveis que formatam uma sala de aula não permitem encontrar "uma única raiz para a equação”. Um sistema didático formado por professor, alunos e saber pode adquirir diversos formatos, todos eles capazes de gerar situações de aprendizagem.

O que posso concluir então a respeito da pergunta-chave? Em vez de dar uma resposta objetiva, procurarei sintetizar algumas reflexões feitas nesse percurso, entre elas, que fatores favorecem/desfavorecem a concretização de uma situação adidática, planejada para tal.

- $\quad$ Primeiramente, o Contrato Didático interfere muito nas possibilidades que se abrem para uma situação adidática. É incrível o poder que o Contrato Didático exerce em uma sala de aula. Se em suas cláusulas constam que só tem valor a atividade que vale nota, ou que resolver um problema matemático é concatenar números e operações, ou que aprender Matemática é apenas uma formalidade que nada tem a ver com suas vidas, ou ainda que Matemática é um conjunto de técnicas cujo sentido não é necessário compreender, é preciso romper esse contrato e criar outro. Mas romper um contrato antigo não é tão fácil assim. Parece que um contrato implícito tem muito mais poder que um contrato feito com papel e caneta. Se ele é implícito, são implícitas também as formas em que se encontra registrado. Esse, ao meu ver, é um problema central da Educação Matemática e da formação de professores de Matemática: existem cláusulas indesejáveis que parecem perpetuarem-se nos contratos de diferentes sistemas didáticos. Que fatores determinam a existência dessas cláusulas? É possível fazer uma reforma no ensino que eliminem essas cláusulas indesejáveis para os futuros estudantes? É possível fazer com que os estudantes aceitem outro contrato, quando já estão envolvidos por um? É possível fazer com que nós professores aceitemos outro 
contrato, quando nós mesmos através de nossa experiência escolar estamos acostumados com as velhas cláusulas? Se for possível, como fazer?

- $\quad$ Em segundo lugar, uma Sequência Didática pode sim ser privilegiada em termos de possibilidades adidáticas, favorecendo desse modo uma aprendizagem mais autônoma e muito mais próxima dos objetivos que se pretendem nos documentos oficiais. A narrativa, como era de se esperar, revelou grande potencial tanto para dar coesão às atividades, quanto para contextualizar o conteúdo no cotidiano de uma jovem de idade próxima à dos alunos, promovendo assim a empatia e a motivação. $\mathrm{O}$ caráter desafiador, utilizando-se o termo "desafio" em vez de exercício, levou-nos para o caminho certo: raciocinar - o desafio é algo novo, sendo assim, os alunos não têm o que repetir, nem de onde copiar a resposta. A resolução em grupo também foi um ponto forte na aplicação dessa sequência e isso vai ao encontro das ideias de Vigotski exploradas no primeiro capítulo - o meio social é a alavanca da aprendizagem, desde que, no caso da escola, seja bem direcionado pelo professor. Em suma, situações adidáticas são imprevisíveis a priori, mas podemos propor atividades que propiciem mais ou propiciem menos o surgimento dessas situações.

- A principal atividade do professor que se preocupa em criar situações potencialmente adidáticas é a de planejamento, pois nela irá elaborar Sequências Didáticas apropriadas, levando-se em consideração o conhecimento que já possui de seus alunos e preparando recursos adequados, sejam eles materiais ou simbólicos. As escolas que observamos nesta pesquisa (SESI e EA-FEUSP), bem como a Instituição em que trabalho atualmente (IFSP) valorizam a atividade de planejamento do professor remunerando-os inclusive para isso, mas infelizmente essa valorização não é comum nas políticas das principais redes de ensino público do nosso país. Na concepção ingênua de que o professor transmite o conhecimento e o aluno absorve-o, de fato, é necessário pouco planejamento. Mas consideramos que é função do professor elaborar situações que despertem o interesse e a aprendizagem; enriquecer o meio para que o aluno, raciocinando, seja capaz de formular e testar hipóteses, as quais posteriormente o professor irá institucionalizar. Desse modo, o esquema 2, na seção 1.3.2 desse trabalho, sintetiza dois papéis que são assumidos pelo professor em dois diferentes espaços: o professor que prepara sua aula na situação metadidática e o professor ensinando na situação didática. A imagem do professor sempre está ligada a esse segundo papel, mas devemos saber que uma situação adidática só ocorre se houver a duplicidade de papéis do professor, essencial para o ensino, essencial mesmo para 
que o aluno sinta a importância que o professor atribui ao processo de ensino e aprendizagem, podendo então ele mesmo atribuir importância a tal.

- $\quad$ O professor tem, também, na situação adidática o papel de realizar a devolução e de orientar a atividade do aluno. Pude perceber, no terceiro momento, a importância dos bolsistas para intervirem em casos de contra devolução, que decorreram da insegurança dos alunos e nos casos de interpretação equivocada do desafio por parte dos alunos; também para interpretarem a dificuldade dos alunos e valorizarem o seu raciocínio e, finalmente, para formalizar o raciocínio e a linguagem desenvolvidos pelos alunos em torno do conteúdo específico, no caso, Análise Combinatória.

- Também concluí algo que, por mais óbvio que pareça, nunca me esteve tão claro. É o aluno que decide se irá aprender ou não. E se o professor acha inútil pensar estratégias para convencê-lo da importância que aquele conteúdo tem, gastará seu tempo "ensinando" algo que não será aprendido. A atividade de convencimento se dá não só em cada conteúdo, mas em cada problema. Numa visão pessimista, isso significaria atribuir ao aluno a responsabilidade por não aprender. Mas, na perspectiva deste trabalho, e tomando como pressuposto o compromisso que cada professor tem com o ensino, isso significa atribuir ao professor a responsabilidade de proporcionar experiências ricas de aprendizagem.

- $\quad$ Percebi que a devolução vai além de convencer o aluno da importância de realizar a atividade, ela engloba a compreensão do desafio proposto e de seu significado; a necessidade real de resolver o desafio e desencadeia também as necessidades de ação, formulação, validação e institucionalização, gerando inclusive o desejo de continuar aprendendo. De todas essas etapas, o professor pode participar sem a necessidade de antecipar o raciocínio do aluno.

- Concluí ainda que de nada serve realizar a devolução se não for dado tempo suficiente para que o aluno chegue a alguma conclusão, pois de acordo com as concepções adotadas nos referenciais teóricos desse trabalho, a aprendizagem só será efetiva se adquirida numa experiência pessoal. No primeiro momento da aplicação da Sequência Didática, percebi o quanto as "explicações na lousa" eram vazias de significado para os alunos que ainda não tinham respondido por eles mesmos ao desafio. Eles continuavam sem entender, mas não tinham mais a motivação de responder ao desafio, pois já sabiam a resposta. Eu pensava, naquele momento, que estava "transmitindo" o conhecimento para os alunos que não haviam finalizado o desafio. Mas, sendo coerente com nossa perspectiva de aprendizagem, transmitir 
conhecimento simplesmente é impossível. Então, o que eu estava fazendo na lousa naquela ocasião com relação aos que ainda não tinham concluído o desafio? Dando a resposta do desafio, interrompendo uma experiência e, com isso, destruindo a possibilidade de aprendizagem. A tendência de antecipar o raciocínio que deve ser do aluno precisa ser evitada, pois essa atitude pode prejudicar tanto o entendimento deste raciocínio, quanto a auto-confiança do aluno para prosseguir a situação adidática.

- Percebi através dessa pesquisa e das reflexões sobre a microgênese do desenvolvimento e o conceito de Zona de Desenvolvimento Proximal, que as experiências são pessoais, que as trajetórias são únicas e que, portanto, não podemos esperar que todos os alunos estejam no mesmo nível de desenvolvimento. Isso não era claro para mim, pensava que se todos se envolvessem com a atividade, todos teriam um aprendizado idêntico. Acredito agora que deve haver igualdade de oportunidades, mas que nunca haverá igualdade de aprendizados, qualquer que seja a situação. Acredito também que para haver igualdade de oportunidades é preciso permitir que os alunos troquem experiências, isto é, trabalhem em grupos. É importante também uma atenção especial do professor para cada aluno com suas especificidades. Sabemos das dificuldades do professor, que simultaneamente é responsável por até quarenta alunos. Mas é preciso buscar alternativas. Mostramos neste trabalho o exemplo da Escola de Aplicação que utiliza o PIBID para dar atenção às individualidades. Outras escolas públicas têm feito excelente uso desse programa federal.

- $\quad$ E, por último, concluo que apenas o fato de estar interessado em produzir situações potencialmente adidáticas demonstra que o professor compreende exatamente o que é aprender e o que é ensinar. Situação adidática é apenas um construto, ou seja um termo científico criado e definido para designar um conceito ou fenômeno ao qual queremos nos referir. Mas existe uma postura docente coerente com essa ideia e, independe da existência do termo, tal postura valoriza cada aluno como capaz de aprender; não ignora os problemas concretos de nosso sistema educacional, mas vê na sala de aula uma oportunidade de mudanças individuais; demonstra que o saber matemático é possuidor de valor próprio; explora recursos e meios de modo que o aluno aprenda por sua própria atividade e seja capaz de continuar aprendendo mesmo fora da escola; promove o prazer de aprender e raciocinar, pois ele mesmo possui esse prazer; e, por fim, assume a sua responsabilidade de ensinar, ainda que esse verbo não tenha um significado tão simples como eu acreditava no início dessa pesquisa. 


\section{Referências bibliográficas}

ALCÂNTARA, S. D. Educação Matemática: uma introdução. São Paulo: EDUC, 1999.

ARAÚJO, P. B. Situações de aprendizagem: a circunferência, a mediatriz e uma abordagem com o Geogebra. São Paulo: 2010. Dissertação de mestrado profissional, Pontifícia Universidade Católica de São Paulo.

ARTIGUE, M. Engenharia Didática. In: BRUN, J. Didáctica das Matemáticas, Lisboa: Instituto Piaget, 1996. p. 193-217.

ASTOLFI, J. P e DEVELAY, M. A. A didática das ciências. Campinas: Papirus, 1990.

ASTOLFI, Jean-Pierre et al.. Mots-clés de la didactique des sciences: repères, définitions, bibliographies. Bruxelles: De Boeck \& Larcier, 1997.

AZEVEDO, M. C. P. S. Situações de ensino-aprendizagem: Análise de uma Sequência Didática a partir da Teoria das Situações de Brousseau. São Paulo: 2008. Dissertação de mestrado, Faculdade de Educação - USP.

BRASIL. Ministério da Educação. Secretaria de Educação Média e Tecnológica. Parâmetros curriculares nacionais (Ensino Médio). Brasília: MEC, 2000.

Ministério da Educação. Conselho Nacional de Educação. Diretrizes

Curriculares Nacionais para o Ensino Médio. Brasília: MEC, 2012.

Ministério da Educação. Instituto Nacional de Estudos e Pesquisas Educacionais Anísio Teixeira - INEP. Relatório Nacional do PISA, Brasília: 2001.

. Pibid- Programa Institucional de Bolsa de Iniciação à docência. Disponível em http://www.capes.gov.br/educacao-basica/capespibid, visualizado em junho/2014.

BOURDIEU, P. A "juventude" é apenas uma palavra. In Questões de sociologia. Rio de Janeiro: Marco Zero,1983. 
BROUSSEAU, G. Fondements et méthodes en didactique des mathématiques, Recherches en didactique des mathématiques, Grenoble, 1986, v. 7, n. 2 , p. 35 - 115.

Os diferentes papéis do professor.In: PARRA, Cecília; SAIZ, Irma (org). Didática da Matemática: Reflexões Psicológicas. Porto Alegre: Artes Médicas, 1996. Cap. 4. p. 48-72.

Glossaire de quelques concepts de la théorie des situations didactiques en mathématiques, 1998. Disponível em http://guy-brousseau.com/wpcontent/uploads/2010/09/Glossaire_V5.pdf, visualizado em junho/2014.

. Introdução ao estudo da Teoria das Situações Didáticas: conteúdos e métodos de ensino [tradução Camila Bogéa]- São Paulo: Ática, 2008.

CERRI, C. ; DRUCK, I. F. ; PEREIRA, A. L. . Combinatória sem Fórmulas. São Paulo: Secretaria do Estado da Educação de São Paulo, 2002 (Material de Apoio do Programa PEC- Construindo Sempre)

CHEVALLARD, Y. La transposición didáctica: del saber sabio al saber enseñado. Buenos Aires: Aique, 1991.

CRUZ, M. O. Construção da identidade pessoal e do conhecimento: a narrativa no ensino de Matemática. Dissertação de mestrado: USP, 2006.

DANIELS, H. Abordagens atuais da teoria sociocultural e da teoria da atividade. In: Vygotsky e a Pedagogia, São Paulo: Edições Loyola, 2003, p. 93-125.

FINO,C. N. Vigotski e a Zona de Desenvolvimento Proximal (ZDP): três implicações pedagógicas. In: Revista Portuguesa de Educação, v. 14, n², p. 273- 291, disponível em <http://www3.uma.pt/carlosfino/publicacoes/11.pdf>. Última visualização: 05/05/2011

FONSECA, C. Quando cada caso NÃO é um caso: pesquisa etnográfica e educação. Revista Brasileira de Educação, Rio de Janeiro, n.10, p.58-78, 1999.

FONTANIVE, N.S.; KLEIN, R.e RODRIGUES S. S. Boas práticas docentes no ensino da Matemática. São Paulo: Cesgranrio, 2011. 
GONÇALVES, M. J. S. V. Raciocínio proporcional: estratégias mobilizadas por alunos a partir de uma abordagem envolvendo oralidade. Campo Grande: 2010. Dissertação de mestrado, Universidade Federal do Mato Grosso do Sul.

JONNAERT, Philippe. Dévolution versus contre-dévolution! Un tandem incontournable pourle contrat didactique. In: RAISKY, Claude: CAILLOT, Michel (éds) Au-delà des didactiques, Le didactique: débats autour de concepts fédérateurs. Belgium: De Boeck \& Larcier S. A. 1996, 278p.

MACHADO, N. J. - Educação: projetos e valores. São Paulo: Escrituras, 2000. - Educação: competência e qualidade. São Paulo: Escrituras, 2009.

MARTINS, M. C. Avaliação: do persecutório olhar autoritário à avaliação para a práxis pedagógica. In: FREIRE, Madalena et. al.. Avaliação e Planejamento: a prática educativa em questão. Instrumentos metodológicos II. São Paulo: Espaço Pedagógico, 1997. p 41-53.

MEIHY, J. Manual de história oral. São Paulo: Edições Loyola, 1996.

MORGADO e outros. Análise Combinatória e Probabilidade. Rio de Janeiro: IMPA VITAE, 1991.

NEHRING, C. M.. Compreensão de texto: enunciados de problemas multiplicativos elementares de Combinatória. Florianópolis: 2001. Tese de doutorado, Universidade Federal de Santa Catarina.

OLIVEIRA, M.K. Vygotsky -Aprendizado e desenvolvimento: Um processo sócio-histórico. São Paulo, Scipione, 1993.

PAIS, L. C. Didática da Matemática: uma análise da influência francesa. Belo Horizonte: Autêntica, 2002.

PERRENOUD, Philippe. Construir as Competências desde a Escola. Trad. Bruno Charles Magne. Porto Alegre: Artes Médicas Sul, 1999.

PINHEIRO, C. A. M. O ensino de Análise Combinatória a partir de situações-problema. Belém: 2008. Dissertação de mestrado, Universidade do Estado do Pará. 
RICARDO, E. C. Competências, interdisciplinaridade e contextualização: dos Parâmetros Curriculares Nacionais a uma compreensão para o ensino das ciências. Tese de doutorado: UFSC, 2005

ROCHA, J. C. O ensino da Análise Combinatória: uma discussão sobre o uso do princípio multiplicativo na resolução de problemas. Dissertação de mestrado: USP, 2002

ROSENTHAL, R.J.; JACOBSON, L. Expectativas de professores com relação aos alunos pobres. In: A ciência social em um mundo em crise: textos do Scientific American. São Paulo, Perspectiva / EDUSP, 1973. p.199-204.

SALATINO, A.T. Entre laços e redes de sociabilidade. Sobre jovens, celulares e escola contemporânea. Dissertação de mestrado: FEUSP, 2014

SESI. Regimento comum da rede escolar SESI-SP. São Paulo: 2010. Disponível em www.sesisp.org.br/educacao/hArquivo.ashx?Url=10167, visualizado em junho/2014.

TIRAMONTI, G. La escuela en la encrucijada del cambio epocal. Educação \& Sociedade, Campinas, v.26, n.92, p.889-910, 2005.

USP. Regimento EA-FEUSP. São Paulo: 2006. Disponível em http://www2.ea.fe.usp.br/wpcontent/uploads/2014/05/Regimento-escolar-EA.pdf, visualizado em junho/2014.

VIGOTSKI, L. S. Psicologia pedagógica. São Paulo: Martins Fontes, 2010

WATANABE, R. Nossos alunos sabem pensar? Revista do Professor de Matemática, $\mathrm{n}^{\circ} 62$. SBM, 2007

ZABALA, A. A prática educativa: como ensinar. Porto Alegre: ArtMed, 1998 


\section{ANEXOS \\ QUESTIONÁRIO PARA OS LICENCIANDOS EM MATEMÁTICA DO IME-USP BOLSISTAS DO PIBID NA ESCOLA DE APLICAÇÃO QUE PARTICIPARAM DO PROJETO “A CIDADE DE CONTAGEM”- SET/2014}

Pretendíamos que a Sequência Didática "A cidade de Contagem" permitisse aos alunos vivenciarem uma situação adidática, ou seja, que eles por sua própria experiência encontrassem a organização lógica da Análise Combinatória.

Para isso, precisaria ocorrer a devolução, isto é, a necessidade de resolver o problema deveria ser sentida pelo próprio aluno.

Para isso também, vocês deveriam orientá-los, realizando por fim a institucionalização do conhecimento.

1. Quanto aos alunos:

a) Sentiram a necessidade de resolver os desafios?

( ) não ( ) sim, sozinhos ( ) sim, com dicas dos bolsistas ( ) sim, totalmente orientados pelos bolsistas

b) Listaram todas as possibilidades sem fazer esquemas?

( ) não ( ) sim, sozinhos ( ) sim, com dicas dos bolsistas ( ) sim, totalmente orientados pelos bolsistas

c) Descobriram a necessidade de fazer esquemas (árvore de possibilidades e/ou outro)?

( ) não ( ) sim, sozinhos ( ) sim, com dicas dos bolsistas ( ) sim, totalmente orientados pelos bolsistas

d) Perceberam o princípio multiplicativo?

( ) não ( ) sim, sozinhos ( ) sim, com dicas dos bolsistas ( ) sim, totalmente orientados pelos bolsistas

e) Perceberam a importância de generalizar o raciocínio?

( ) não ( ) sim, sozinhos ( ) sim, com dicas dos bolsistas ( ) sim, totalmente orientados pelos bolsistas

f) Sentiram a necessidade de conhecer as fórmulas de Análise Combinatória?

( ) não ( ) sim, sozinhos ( ) sim, com dicas dos bolsistas ( ) sim, totalmente orientados pelos bolsistas Observações: 
2. Quanto aos recursos utilizados:

\begin{tabular}{|c|c|c|c|}
\hline & $\begin{array}{l}\text { Contribuiu para } \\
\text { que houvesse a } \\
\text { devolução: }\end{array}$ & $\begin{array}{l}\text { Contribuiu para } \\
\text { que houvesse } \\
\text { aprendizagem: }\end{array}$ & $\begin{array}{c}\text { Contribuiu para } \\
\text { que houvesse } \\
\text { uma situação } \\
\text { adidática: }\end{array}$ \\
\hline $\begin{array}{l}\text { a) A narrativa "A cidade de } \\
\text { Contagem" }\end{array}$ & $\begin{array}{l}\text { ( ) nada } \\
\text { ( ) pouco } \\
\text { ( ) razoavelmente } \\
\text { ( ) muito }\end{array}$ & $\begin{array}{l}\text { ( ) nada } \\
\text { ( ) pouco } \\
\text { ( )razoavelmente } \\
\text { ( ) muito }\end{array}$ & $\begin{array}{l}\text { ( ) nada } \\
\text { ( ) pouco } \\
\text { ( ) razoavelmente } \\
\text { ( ) muito }\end{array}$ \\
\hline $\begin{array}{l}\text { b) A árvore de } \\
\text { possibilidades }\end{array}$ & $\begin{array}{l}\text { ( ) nada } \\
\text { ( ) pouco } \\
\text { ( ) razoavelmente } \\
\text { ( ) muito }\end{array}$ & $\begin{array}{l}\text { ( ) nada } \\
\text { ( ) pouco } \\
\text { ( ) razoavelmente } \\
\text { ( ) muito }\end{array}$ & $\begin{array}{l}\text { ( ) nada } \\
\text { ( ) pouco } \\
\text { ( ) razoavelmente } \\
\text { ( ) muito }\end{array}$ \\
\hline $\begin{array}{l}\text { c) Letras e números } \\
\text { concretos }\end{array}$ & $\begin{array}{l}\text { ( ) nada } \\
\text { ( ) pouco } \\
\text { ( ) razoavelmente } \\
\text { ( ) muito }\end{array}$ & $\begin{array}{l}\text { ( ) nada } \\
\text { ( ) pouco } \\
\text { ( ) razoavelmente } \\
\text { ( ) muito }\end{array}$ & $\begin{array}{l}\text { ( ) nada } \\
\text { ( ) pouco } \\
\text { ( ) razoavelmente } \\
\text { ( ) muito }\end{array}$ \\
\hline $\begin{array}{l}\text { d) A palavra desafio em vez } \\
\text { de exercício }\end{array}$ & $\begin{array}{l}\text { ( ) nada } \\
\text { ( ) pouco } \\
\text { ( ) razoavelmente } \\
\text { ( ) muito }\end{array}$ & $\begin{array}{l}\text { ( ) nada } \\
\text { ( ) pouco } \\
\text { ( ) razoavelmente } \\
\text { ( ) muito }\end{array}$ & $\begin{array}{l}\text { ( ) nada } \\
\text { ( ) pouco } \\
\text { ( ) razoavelmente } \\
\text { ( ) muito }\end{array}$ \\
\hline e) A presença dos bolsistas & $\begin{array}{l}\text { ( ) nada } \\
\text { ( ) pouco } \\
\text { ( ) razoavelmente } \\
\text { ( ) muito }\end{array}$ & $\begin{array}{l}\text { ( ) nada } \\
\text { ( ) pouco } \\
\text { ( ) razoavelmente } \\
\text { ( ) muito }\end{array}$ & $\begin{array}{l}\text { ( ) nada } \\
\text { ( ) pouco } \\
\text { ( ) razoavelmente } \\
\text { ( ) muito }\end{array}$ \\
\hline $\begin{array}{l}\text { f) O fato de esse ser o } \\
\text { próximo conteúdo da } \\
\text { escola }\end{array}$ & $\begin{array}{l}\text { ( ) nada } \\
\text { ( ) pouco } \\
\text { ( ) razoavelmente } \\
\text { ( ) muito }\end{array}$ & $\begin{array}{l}\text { ( ) nada } \\
\text { ( ) pouco } \\
\text { ( ) razoavelmente } \\
\text { ( ) muito }\end{array}$ & $\begin{array}{l}\text { ( ) nada } \\
\text { ( ) pouco } \\
\text { ( ) razoavelmente } \\
\text { ( ) muito }\end{array}$ \\
\hline
\end{tabular}

Observações:

3. Quanto à sua postura, bolsista:

a) Percebeu, em alguns momentos, que estava antecipando um raciocínio que deveria ser do aluno?

( ) não ( ) sim, poucas vezes ( ) sim, com frequência

b) Evitou, em alguns momentos, antecipar um raciocínio que deveria ser do aluno, apesar da vontade de fazê-lo?

( ) não ( ) sim, poucas vezes ( ) sim, com frequência

c) Achou importante a institucionalização do conhecimento, feita ao término da Sequência Didática? (fórmulas)

( ) não ( ) sim, pouco importante ( ) sim, muito importante

Observações: 


\section{A cidade de Contagem}

Marcela passou no vestibular. A alegria de sua família e amigos foi imensa... Até o momento em que descobriram que ela precisaria fazer as malas. Como a universidade ficava muito longe de casa, Marcela procurou na Internet um lugar para morar, que fosse tranquilo e próximo da universidade.

Durante sua pesquisa, ela descobriu uma cidade com essas características. Chamava-se CIDADE DA CONTAGEM.

Marcela sempre foi conhecida por sua indecisão. Nunca sabia que escolha fazer. Ir para o cursinho à pé ou de ônibus? De tênis ou de bota? À tarde ou de manhã? Era isso inclusive que preocupava as pessoas: como ela iria se virar? Morar sozinha implica em tomar muitas decisões importantes. E como ela faria isso longe de todos?

Mas essa foi a primeira vez que ela não pensou duas vezes, preparou a bagagem, comprou a passagem e cobriu-se de coragem para iniciar a viagem a uma nova fase de sua vida.

Seus amigos e familiares começaram a dar conselhos estranhos, mas ela ignorava, pensando: "Com certeza, eles combinaram tudo isso para me fazer desistir da mudança".

- Não vai pra essa cidade não, minha filha. Dizem que todos que vão pra lá ficam com uma mania esquisita.

- Cidade da contagem? Não acredito que você vai pra lá!!! Você está de brincadeira, né?

- Você nunca ouviu falar do contágio da Contagem? É o assunto do momento... Não sei em que mundo você vive!

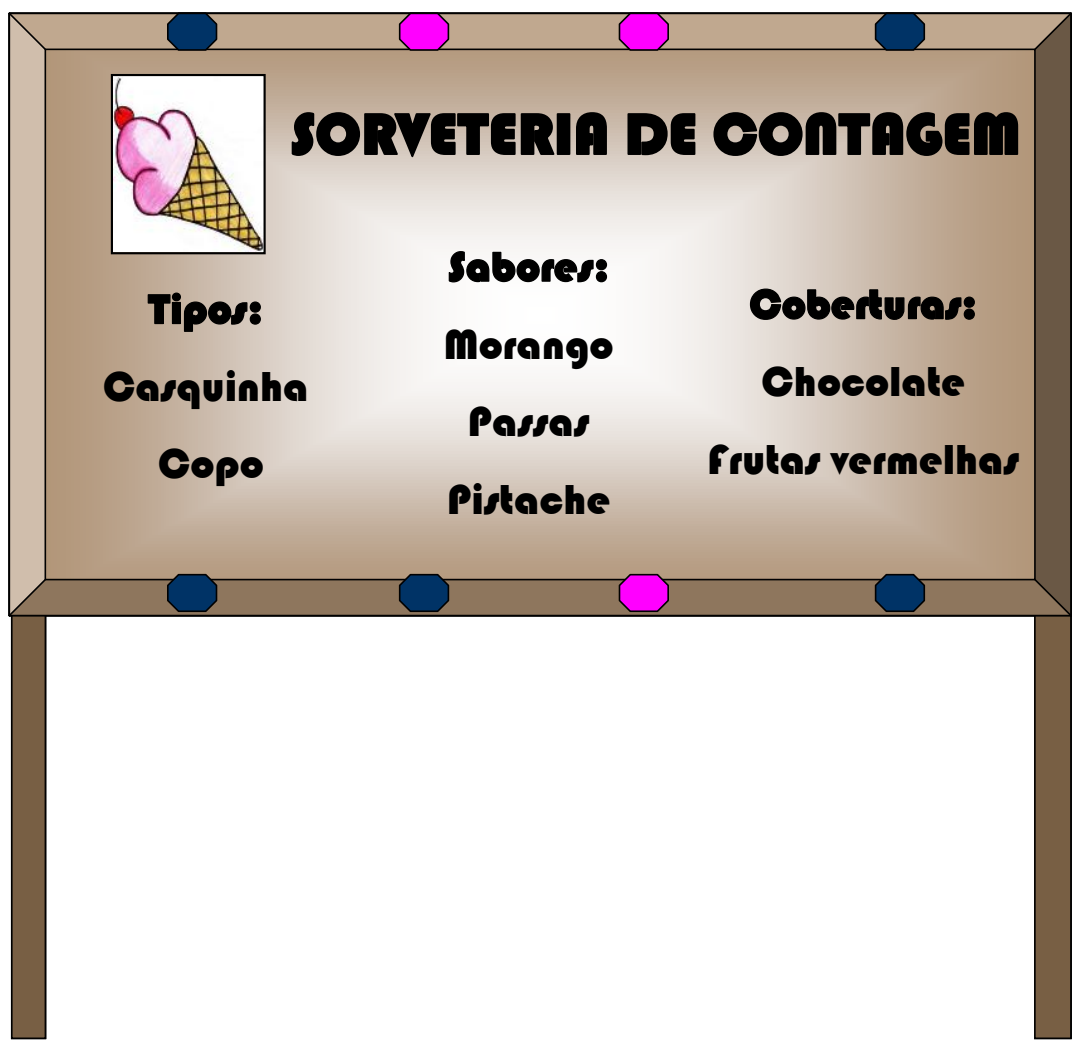

No dia da mudança, o clima estava quente. Assim que entrou na cidade da contagem, Marcela resolveu tomar um sorvete e parou na primeira sorveteria que viu. Ficou por alguns momentos olhando para a placa e não sabia que escolha fazer. $A$ dúvida era tanta que resolveu contar todas as possibilidades que tinha, antes de tomar sua decisão.

DESAFIO 1 - De quantos modos Marcela pode montar seu sorvete, com exatamente uma bola e uma cobertura? 
O sorvete chegou, e com ele a maquineta em que ela deveria digitar a senha do cartão de débito. Marcela havia esquecido a senha completamente. Lembrava apenas que a senha tinha 4 dígitos numéricos e que eram todos ímpares. Não lembrava, nem mesmo, se tinham algarismos repetidos.

Por sorte havia trazido consigo uma quantia em dinheiro. Marcela pagou o sorvete e foi sentar-se para tomá-lo, muitíssimo preocupada, não pela senha, pois bastava ligar para sua mãe e esta lhe diria a senha. Marcela estava preocupada com a solução de um novo desafio.

DESAFIO 2 - Supondo que o cartão não fosse bloqueado depois de várias tentativas e que o sorvete não fosse derreter enquanto ela tentava várias senhas, no máximo, quantas vezes ela precisaria digitar?

A menos de 200 metros do local onde estava sentada, havia uma placa, na qual Marcela fitou o olhar. Marcela, que já ficara muito tempo exposta ao sol, viu as letras da placa se embaralhar. CONTAGEM, NOCTAMEG, ONCGATME, MEGATONC,...

Procurou, rapidamente, um banco para sentar-se à sombra, mas já era tarde demais. Um novo desafio viera the roubar mais alguns minutos de seu pensamento.

DESAFIO 3 - De quantos modos diferentes as letras da palavra CONTAGEM podem se posicionar?

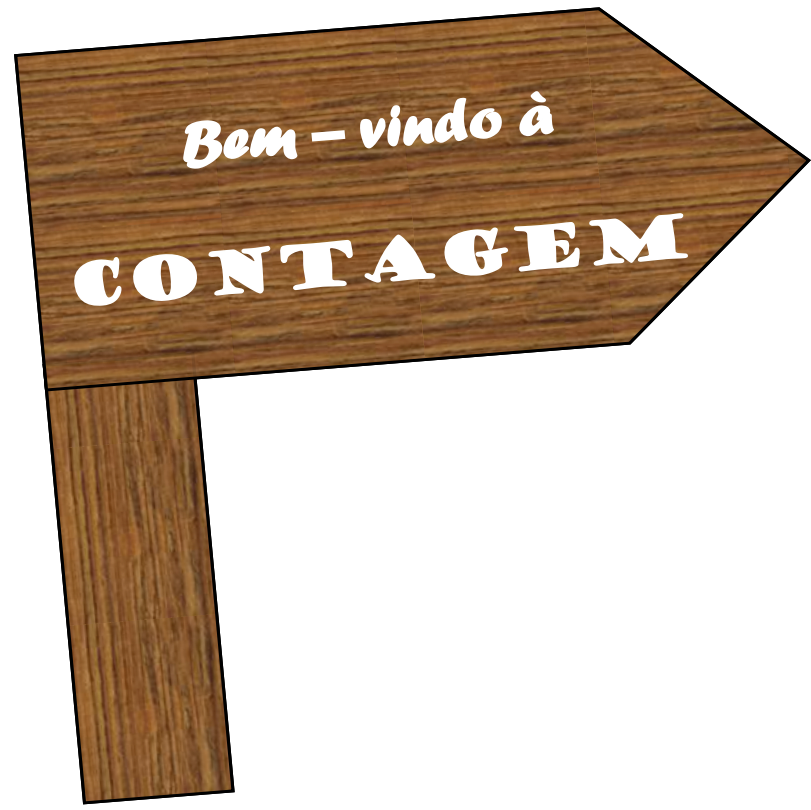

O interessante de tudo isso é que Marcela não escreveu todas as palavras para contá-las uma a uma. Ela elaborou uma estratégia para resolver esse desafio. E a cada novo desafio, ela elaborava uma nova técnica para contar.

Marcela terminou de tomar o sorvete e ligou para sua mãe. Esta, ansiosa por receber o telefonema, fez milhares de perguntas antes de deixar sua filha contar o episódio da senha. Então a mãe de Marcela disse-lhe o número da senha, sucedido por inúmeros conselhos, como era comum.

Depois que desligou o celular, Marcela pensou: "Puxa vida! Se eu tivesse lembrado, ao menos, que na senha não tem 1 nem 9 , e que o único dígito que se repete duas vezes é o $3 . .$. Teria ficado bem mais fácil."

DESAFIO 4 - Com essas dicas, quantas senhas ainda são possíveis? 


\section{VOCÊ SABIA?}

Você sabia que existe mesmo um município chamado Contagem no Brasil? É a terceira maior cidade do Estado de Minas Gerais. O nome surgiu por causa dos postos de registros que tinham na região desde 1716. Contagem foi emancipada em 1911. Atualmente, entre outras coisas, possui um grande parque industrial e, no lazer, um evento tradicional chamado Gincana de Contagem. Se você quer saber mais, é só fazer como Marcela e pesquisar na Internet a respeito desse município.

\section{PARA CASA}

Pense em uma situação que você já vivenciou da qual seria possível extrair um desafio de contagem. Enuncie e resolva o desafio.

\section{MAIS DESAFIOS PARA VOCÊ...}

1. Enquanto esperava o sorvete, Marcela olhava à sua volta, pensando em como seria divertido conhecer novos ambientes e novas pessoas. Pegou a máquina fotográfica e começou a registrar aquele momento. Foi quando a placa da sorveteria lhe chamou a atenção mais uma vez. Agora, eram as 8 luzes em seu contorno, que acendiam e apagavam aleatoriamente, estando sempre pelo menos uma acesa. Começou a pensar: "Quais as lâmpadas que estarão acesas quando eu bater a foto?". E o desafio estava lançado... Responda: De quantos modos diferentes as luzes poderão sair na foto? (Resposta: $\left.2^{8}-1\right)$

2. De quantos modos podem ser embaralhadas as letras do seu nome? (Resposta pessoal)

3. De quantos modos as letras da palavra CONTAGEM poderiam ser embaralhadas

a) iniciando com $C$ e terminando com $M$ ? (R. 720)

b) mantendo as vogais todas juntas? (R. 4.320)

c) sem que as letras T e A fiquem juntas? (R. 39.240)

4. Qual seria a resposta do desafio 2,

a) se não tivessem dígitos repetidos? (R. 120)

b) se não tivessem dígitos repetidos e fossem 5 dígitos em vez de 4? (R. 120)

5. Se a senha de quatro dígitos de Marcela fosse composta apenas por algarismos pares, não podendo começar por 0 , quantas tentativas ela teria de fazer

a) não sabendo se tinham algarismos repetidos? (R. 500)

b) sabendo que não tinham algarismos repetidos? (R. 96)

6. De quantos modos poderia ser escolhido o sorvete se Marcela planejasse pedir duas bolas? (R. 24) 


\section{A cidade de Contagem (parte 2)}

Marcela gostou muito de sua faculdade. Tudo era muito diferente da escola: mais liberdade e mais responsabilidade. Ao término do primeiro dia de aula, a professora coordenadora entrou na sala, dizendo que, dentre os 40 alunos de sua turma, eles deveriam escolher 5 alunos distintos para compor uma comissão de representantes da turma. Cada um dos 5 representantes teria uma função diferente: integração, comunicação, repasse de documentos, participação em assembléias e promoção de eventos. Marcela ficou pensando: De quantos modos diferentes pode ser escolhida essa comissão?

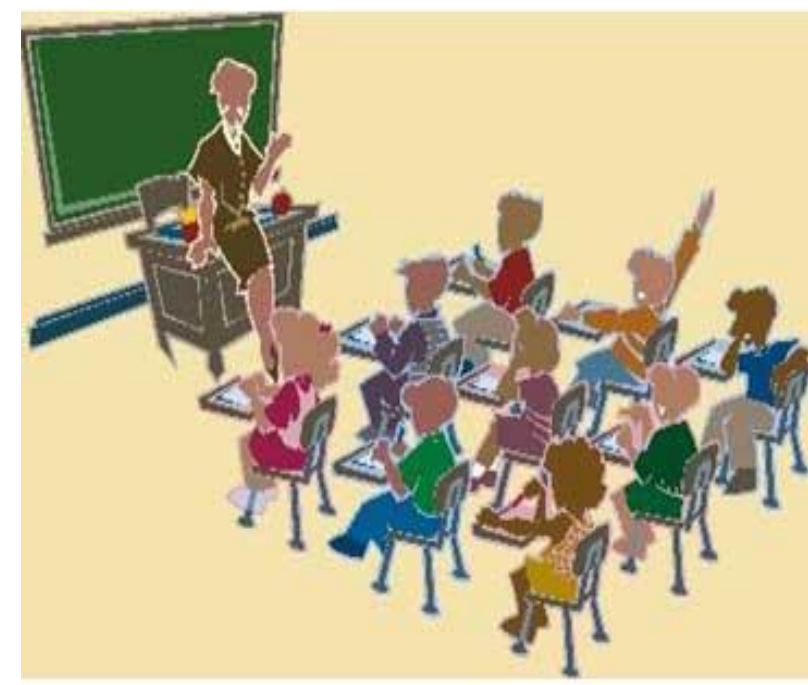

DESAFIO 5 - De quantos modos é possível formar uma comissão de 5 alunos, dentre os 40, de modo que cada um tenha uma função diferente?

Os alunos discutiram e chegaram à conclusão de que não era necessária a divisão de funções. Os 5 integrantes da comissão deveriam trabalhar em conjunto, assumindo todos os papéis de representantes da turma. Marcela logo percebeu que, com essa mudança, o número de comissões possíveis também mudou.

DESAFIO 6 - De quantos modos é possível formar uma comissão de 5 alunos, dentre os 40, não havendo distribuição de tarefas?

Hora de ir para a casa. Marcela pegou o trem com destino à prefeitura Municipal de Contagem e, a partir de lá, iria caminhando até a sua moradia. Tinham seis lugares para se sentar no vagão em que entrou, no entanto, ela sentou-se no primeiro banco próximo à porta, pois suas malas estavam pesadas. Na estação seguinte, ninguém se levantou e entraram no vagão mais 3 mulheres e 2 homens. Enquanto escolhiam os lugares para se sentar, Marcela propôs a si mesma um novo desafio.

DESAFIO 7 - Desprezando a individualidade dos passageiros recém-chegados e levando-se em consideração apenas o sexo, de quantos modos homens e mulheres podem posicionar-se? 


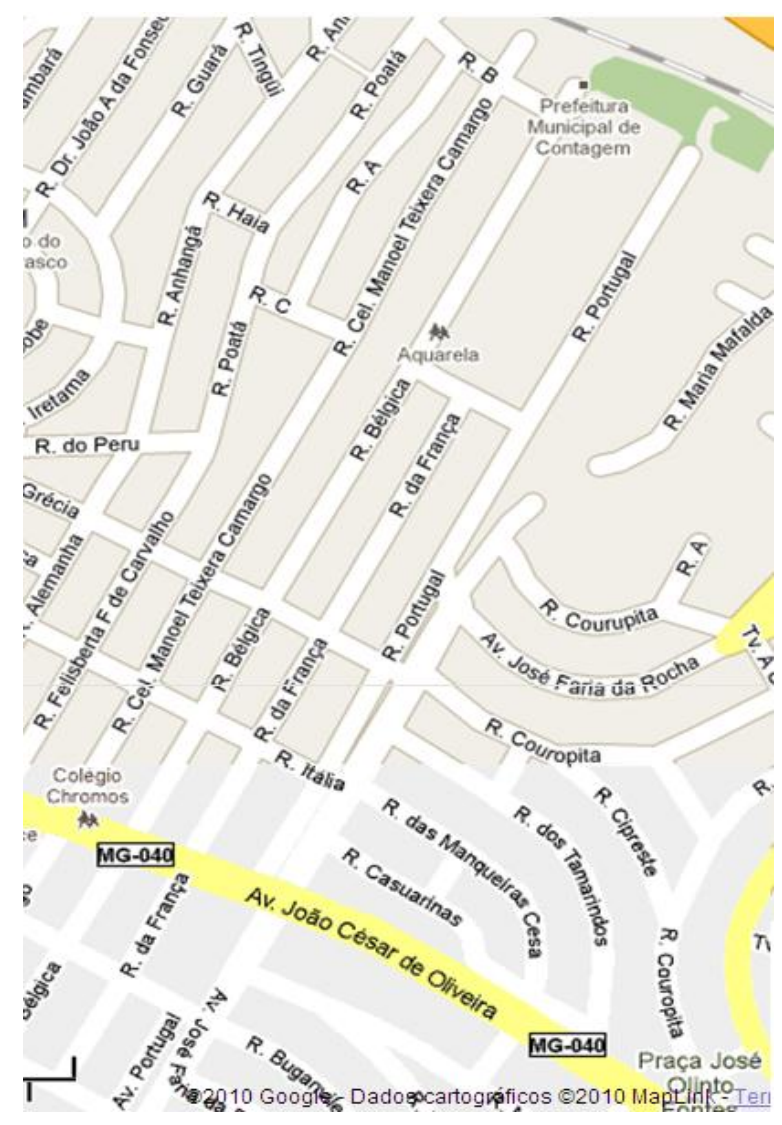

Chegando à Prefeitura Municipal de Contagem, Marcela tirou o mapa do bolso para se localizar.

Marcela está cansada e ainda precisa caminhar cerca de $1 \mathrm{~km}$. A moradia ficava no cruzamento da Rua Portugal com a Avenida João César de Oliveira.

E lá estava ela em dúvida, de novo. Que caminho escolher para voltar para casa?

DESAFIO 8 - Utilizando o menor caminho possível e supondo que todos os quarteirões pelos quais irá passar são retangulares, de quantas maneiras diferentes ela pode chegar ao seu destino?

\section{PARA CASA}

O primeiro semestre acabou e Marcela irá passar, em casa, as suas primeiras férias da faculdade. Como seus familiares e amigos irão agir diante das mudanças que ocorreram com Marcela? Escreva você mesmo, em poucas linhas, essa parte da história. Nela, deverá aparecer um novo desafio de contagem, enunciado e resolvido.

MAIS DESAFIOS PARA VOCÊ...

7. No desafio 5, quantas comissões diferentes seria possivel formar se as 5 funções dos integrantes fossem

a. 1 representante, 1 vice-representante e 3 secretários? (R. 13.160.160)

b. 2 representantes e 3 secretários? (R. 6.580.080)

8. Qual seria a resposta do desafio 7 se houvesse sete lugares vazios em vez de seis? (R. 60)

\section{VOCÊ SABIA?}

Você sabia que ao participar dessa atividade, você contribuiu com a pesquisa em educação?

Muito obrigada!!!! 